\title{
BioCat 2.0
}

$\begin{array}{ll}\text { CD Corley } & \text { JR Hutchison } \\ \text { CF Noonan } & \text { MJ Lancaster } \\ \text { RA Bartholomew } & \text { MC Madison } \\ \text { TL Franklin } & \text { AW Piatt }\end{array}$

September 2013 


\title{
DISCLAIMER
}

This report was prepared as an account of work sponsored by an agency of the United States Government. Neither the United States Government nor any agency thereof, nor Battelle Memorial Institute, nor any of their employees, makes any warranty, express or implied, or assumes any legal liability or responsibility for the accuracy, completeness, or usefulness of any information, apparatus, product, or process disclosed, or represents that its use would not infringe privately owned rights. Reference herein to any specific commercial product, process, or service by trade name, trademark, manufacturer, or otherwise does not necessarily constitute or imply its endorsement, recommendation, or favoring by the United States Government or any agency thereof, or Battelle Memorial Institute. The views and opinions of authors expressed herein do not necessarily state or reflect those of the United States Government or any agency thereof.

\author{
PACIFIC NORTHWEST NATIONAL LABORATORY \\ operated by \\ BATTELLE \\ for the \\ UNITED STATES DEPARTMENT OF ENERGY \\ under Contract DE-AC05-76RL01830
}

Printed in the United States of America
Available to DOE and DOE contractors from the Office of Scientific and Technical Information, P.O. Box 62, Oak Ridge, TN 37831-0062; ph: (865) 576-8401 fax: $(865) 576-5728$
email: reports $a$ adonis.osti.gov
Available to the public from the National Technical Information Service 5301 Shawnee Rd., Alexandria, VA 22312 ph: (800) 553-NTIS (6847) email: orders@ntis.gov <http://www.ntis.gov/about/form.aspx> Online ordering: http://www.ntis.gov




\title{
BioCat 2.0
}

\author{
CD Corley JR Hutchison \\ CF Noonan MJ Lancaster \\ RA Bartholomew MC Madison \\ TL Franklin AW Piatt
}

September 2013

Prepared for

the U.S. Department of Homeland Security

under U.S. Department of Energy Contract DE-AC05-76RL01830

Pacific Northwest National Laboratory

Richland, Washington 99352 



\begin{abstract}
The U.S. Department of Homeland Security (DHS) National Biosurveillance Integration Center (NBIC) was established in 2008 with a primary mission to "(1) enhance the capability of the Federal Government to (A) rapidly identify, characterize, localize, and track a biological event of national concern by integrating and analyzing data relating to human health, animal, plant, food, and environmental monitoring systems (both national and international); and (B) disseminate alerts and other information to Member Agencies and, in coordination with (and where possible through) Member Agencies, to agencies of State, local, and tribal governments, as appropriate, to enhance the ability of such agencies to respond to a biological event of national concern; and (2) oversee development and operation of the National Biosurveillance Integration System (NBIS)." Inherent in its mission then and the broader NBIS, NBIC is concerned with the identification, understanding, and use of a variety of biosurveillance models and systems.
\end{abstract}

The goal of this project is to characterize, evaluate, classify, and catalog existing disease forecast and prediction models that could provide operational decision support for recognizing a biological event having a potentially significant impact. Additionally, gaps should be identified and recommendations made on using disease models in an operational environment to support real-time decision making. 



\section{Acronyms and Abbreviations}

DHS

HHS

IT

LANL

NBIC

NBIS

SME

SMW

TRL

USDA
U.S. Department of Homeland Security

U.S. Department of Health and Human Services

information technology

Los Alamos National Laboratory

National Biosurveillance Integration Center

National Biosurveillance Integration System

subject matter expert

Semantic MediaWiki

Technology Readiness Level

U.S. Department of Agriculture 



\section{Contents}

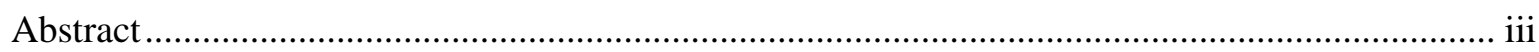

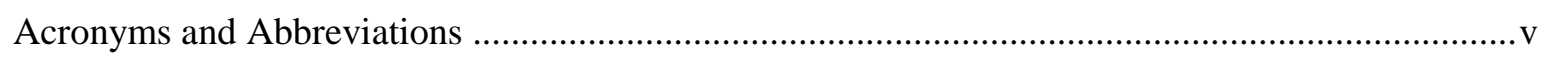

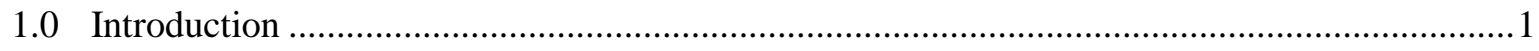

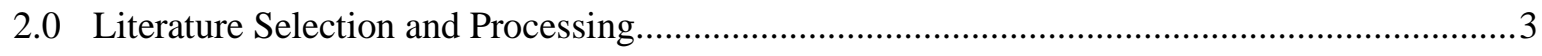

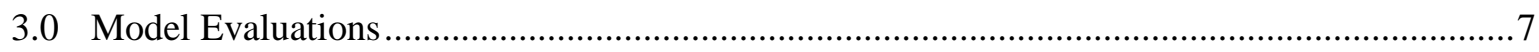

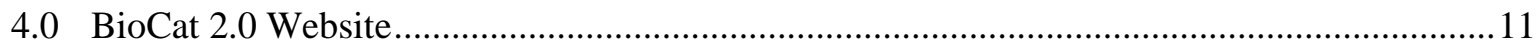

4.1 Needs and Limitations of the BioCat 1.0 Website ..................................................... 11

4.2 Updating Software to Meet the Needs of BioCat 2.0 ...................................................... 12

4.2.1 Benefits of the Drupal Web-Based Content Management Platform ...................... 12

4.2.2 Implementation of Publications Review Workflow for BioCat .............................12

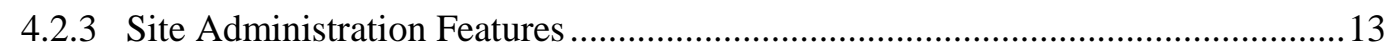

4.2.4 Filtered Display of Content with Faceted Browsing ...........................................13

4.2.5 Current Software for BioCat 2.0 Website ......................................................... 14

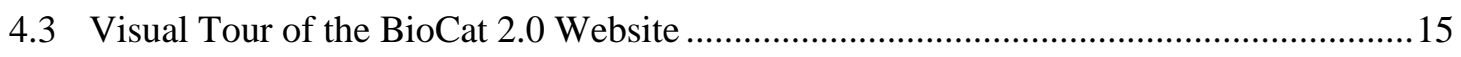

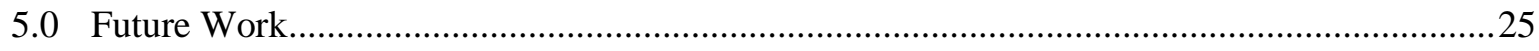

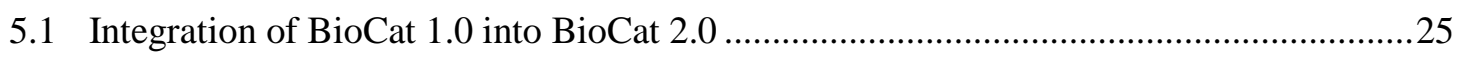

5.2 Enabling BioCat Accessibility on Mobile Devices ....................................................26

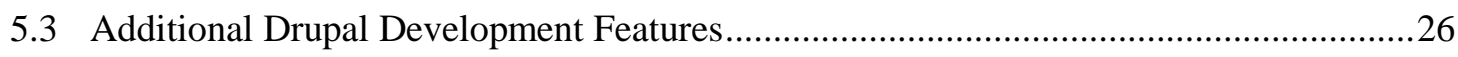

Appendix A Biosurveillance Modelers and Stakeholders .......................................................... A.1

Appendix B Client-Identified Source Lists for Agents, Toxins, and Pathogens of Interest ........... B.1

Appendix C De-duplicated List of Agents, Toxins, and Pathogens of Interest ............................ C.1

Appendix D Prioritized List of Agents for BioCat ................................................................. D. 1

Appendix E Disease Forecast and Prediction Model Evaluation Metrics \& Definitions ............... E.1

Appendix F BioCat Evaluation \& Workflow Data Fields ............................................................ 1

\section{Tables}

Table 2.1. Databases Used to Identify Biosurveillance Modeling Literature ................................. 4

Table 2.2. Additional Keywords Used to Refine and Identify Biosurveillance Modeling

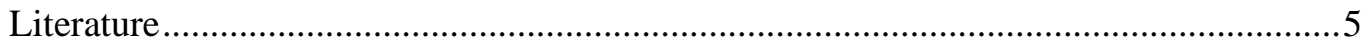

Table 3.1. Initial Definitions of Operational Readiness Levels for Disease Prediction Models........8

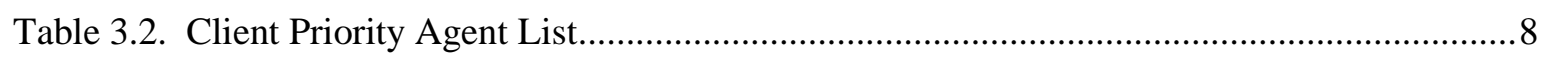





\subsection{Introduction}

The National Biosurveillance Integration Center (NBIC) mission is to enhance the capability of the Federal Government to rapidly identify, characterize, localize, and track a biological event of national concern by integrating and analyzing data relating to human health, animal, plant, food, and environmental monitoring systems (both national and international); and disseminate alerts and other information to Member Agencies and to agencies of State, local, and tribal governments, to enhance the ability of such agencies to respond to a biological event of national concern.. PNNL has supported the operational biosurveillance modeling needs of NBIC in a project funded by the U.S. Department of Homeland Security (DHS) Science and Technology Directorate (S\&T) to identify, characterize, and catalog models that could be used in an operational environment.

A rich and diverse field of infectious disease modeling has emerged in the past 60 years and has advanced our understanding of population- and individual-level disease transmission dynamics, including risk factors, virulence, and spatio-temporal patterns of disease spread. These modeling techniques span domains such as biostatistical, massive agent-based, biophysical, ordinary differential equation, and ecological-niche models. Diverse data sources are being integrated into these models as well, including demographics, remotely sensed measurements and imaging, environmental measurements, and surrogate data such as news alerts and social media. Moreover, nascent research is occurring at the omics-level to aid in forecasting future epidemics; such research includes phylogenetic techniques for predicting pathogen mutations, algorithms for microbial identification in next-generation technologies, metagenomics, and multi-scale systems biology. Yet emerging infectious diseases continue to impact health and economic security across the globe. There remains a gap in the sensitivity and specificity of these modeling forecasts designed not only to track infectious disease events but also to predict disease occurrence. For an example, one needs to look no further than the $2009 \mathrm{H} 1 \mathrm{~N} 1$ influenza pandemic. The latency between identification and characterization of the virus's pathogenicity and transmissibility caused, perhaps, unnecessary mitigation measures such as school and business closures. Moreover, there are strong indicators that dynamics and emergence of vector-borne diseases are in flux because of, among other factors, changes in land use, human behavior, and climate.

The goal of this systematic review was to identify areas for research to characterize the viability of biosurveillance models to provide operationally relevant information to decision makers about disease events. We define a disease event to be a biological event within the context of One Health and all-hazard paradigms. These events are characterized by evidence of condition and risk. These are neither mutually exclusive nor limited to the following examples for evidence of condition: person-to-person transmission (e.g., Mycobacterium tuberculosis), zoonoses (e.g., Francisella tularensis), foodborne pathogens (e.g., Salmonella), vector-borne pathogens (e.g., equine encephalitis virus), waterborne pathogens (e.g., Vibrio cholerae), airborne pathogens (e.g., influenza), animal-to-animal transmission (e.g., Aphtae epizooticae), and plant pathogens (e.g., soybean and wheat rusts). Examples for evidence of risk are accidental or deliberate events affecting air or water quality (e.g., volcanic ash, pesticide runoff), economically motivated adulteration of the food and pharmaceutical supply, and intentional release. In the context of this article, a biosurveillance model is broadly defined as an abstract computational, algorithmic, statistical, or mathematical representation that produces informative output related to all-hazards event detection or event risk. The model is formulated with a priori knowledge and may ingest, process, and analyze data. A biosurveillance model may be proactive or anticipatory (e.g., used to detect or forecast an event, respectively), it may assess risk, or it may be descriptive (e.g., used to understand the dynamics or 
drivers of an event). The evaluation of biosurveillance models and data sources provides key information to enable the identification of gaps and recommendations for improvements to existing models to optimize the utility of the models in an operational environment. This scientifically driven process ensures that the capabilities and limitations of biosurveillance models and data streams are understood by potential users and stakeholders, and result in a path forward toward enhancing biosurveillance capabilities.

For reference, the statement of work for PNNL's Fiscal Year 2013 (FY13) effort is provided below. The report aligns with the logical flow of our work rather than task by task.

\section{Task 1: Continue identification and characterization of operational biosurveillance models}

PNNL will identify, evaluate, and catalog existing syndromic surveillance, indicator systems, and event-detection biosurveillance models published during FY12-13. The focus of this task will be to use the attributes and approach developed in the previous work with NBIC to identify, evaluate, and catalog existing event-detection biosurveillance models.

Subtask 1.1: Identify syndromic surveillance, indicator systems, and operational event-detection biosurveillance models. We will first identify event-detection biosurveillance models operationally deployed by government, industry, academia, and foreign and global organizations.

Subtask 1.2: Evaluate models identified in Subtask 2.1 with the model characterization plan developed in the first BioCat effort. We will expand the attributes and develop quantitative metrics that will then be applied to prediction and forecast biosurveillance models.

Subtask 1.3: Catalog models. We will maintain and store the biosurveillance model catalog within a MediaWiki open-source wiki framework that was created under the previous work with NBIC. The catalog is hosted at http://biocat.pnnl.gov and is accessible via the web. and access is controlled through user/password authentication.

Subtask 1.4: Collaboration and Sharing. We will travel to meet with the Sponsor, collaborate with analysts to ensure BioCat's operational relevance. Additionally, PNNL may submit and participate in biosurveillance- or biodefense-related conferences to promote the NBIC/NBIS and BioCat for community use.

\section{Task 2: Back-identify, characterize and catalog operational biosurveillance models}

PNNL will identify, evaluate, and catalog existing syndromic surveillance, indicator systems, and event-detection biosurveillance models, published during calendar year 2011 and 2012 (CY11-12). The focus of this task will be to use the attributes and approach developed in the previous work with NBIC to identify, evaluate, and catalog existing event-detection biosurveillance models.

Subtask 2.1: Identify syndromic surveillance, indication, and operational event-detection biosurveillance models. We will first identify event-detection biosurveillance models operationally deployed by government, industry, foreign and global organizations during CY11-12. 
Subtask 2.2: Evaluate models identified in Subtask 2.1 with the model characterization plan developed in BioCat Phase 1. Leveraging the quantitative analysis and through following the vetted characterization plan, each event-detection biosurveillance model will be evaluated. Additionally, PNNL will evaluate models not yet evaluated discovered during BioCat Phase 1.

Subtask 2.3: Review the discovered models from BioCat phase 1 and identify models with peerreviewed conference publications and abstracts. Then evaluate those models with the same rubric as in Task 1.

Subtask 2.4: Catalog models. We will maintain and store the biosurveillance model catalog within a MediaWiki open-source wiki framework that was created under the previous work with NBIC. The catalog is hosted at http://biocat.pnnl.gov and is accessible via the web, and access is controlled through user/password authentication.

\section{Task 3: Maintain the BioCat for NBIS/NBIC, and Update Software}

PNNL will host the BioCat for the DHS Office of Health Affairs NBIS/NBIC. The model catalog continues to provide value to biosurveillance stakeholders across the government and academia. BioCat is located at PNNL on a webserver that was purchased by DHS S\&T and is accessible via the Internet. The software framework on which BioCat is built must be updated periodically with security patches and modified configurations.

Subtask 3.1: PNNL will ensure the BioCat remains operational and accessible via the internet.

Subtask 3.2: A variety of projects at PNNL utilize the Knowledge Encapsulation Framework (KEF) software and fund the development of new software and upgrades. Funding under this subtask will ensure that the upgrades developed for other programs are integrated into BioCat.

Subtask 3.3: Coordinate with interagency biosurveillance efforts, and where possible leverage interagency resources and integrate within BioCat. PNNL will also integrate the NBIC's open RSS feed within the BioCat to be viewable by BioCat users.

\subsection{Literature Selection and Processing}

To provide a comprehensive list of biosurveillance models, the PNNL team took two approaches. In the first approach, PNNL staff contacted subject matter experts (SMEs) in academia and government to discuss existing biosurveillance models. A literature search (the active identification of existing information sources most relevant to the research question or need) was performed in the second approach to comprehensively identify biosurveillance models in the scientific, grey, and limiteddistribution literature. One of the main goals of the FY13 funding for BioCat was to identify relevant biosurveillance literature since the end of the last increment of funding in 2011. We identified and pursued several lines of inquiry.

1. Identify people and institutions working in the domain of biosurveillance.

2. Scope agents, pathogens and toxins of interest to NBIC. 
3. Conduct targeted literature searching in salient databases from 2011 to present.

4. Vet literature with subject matter experts.

5. Acquire materials for evaluation.

6. Refine list of papers for evaluation based on NBIC prioritization.

7. Import literature citations into Drupal (open source content management platform).

The first task was to update our people and institutions list. This effort involved reviewing the original list from the previous effort and updating contact information and websites of experts and research institutions focused on the topic of biosurveillance. This information is provided in Appendix A.

The second task was to understand the agents, pathogens, and toxins of interest to NBIC. We received nine lists, including several from the Centers for Disease Control and Prevention (CDC) and the U.S. Department of Agriculture (USDA) as provided in Appendix B. Extensive effort was taken to deduplicate these lists and develop a list of synonyms for each (Appendix C).

Following the de-duplication of the lists of interest, targeted literature searches were conducted. Twelve research databases were queried (Table 2.1). Four additional databases were used in the first round of BioCat literature identification in 2010-2011. By the time targeted searches were performed in 2013, GeoRef, Pollution Abstracts, and Toxicology Abstracts had been cancelled at PNNL due to low use.

Table 2.1. Databases Used to Identify Biosurveillance Modeling Literature

\begin{tabular}{ll}
\hline Database & Database Provider \\
\hline Academic Search Complete & EBSCOHost; Open Source Center \\
ASFA: Aquatic Sciences and Fisheries Abstracts & ProQuest; PNNL Library \\
BioOne Abstracts and Indexes & BioOne, PNNL Library \\
Compendex & Engineering Village, PNNL Library \\
INSPEC & Engineering Village, PNNL Library \\
NTIS & Engineering Village, PNNL Library \\
DTIC (private version) & Defense Technical Information Center \\
Environment Index & EBSCOHost; Open Source Center \\
GreenFILE & EBSCOHost; Open Source Center \\
Google Scholar & Google \\
\hline Homeland Security Digital Library & Naval Postgraduate School \\
International Security \& Counter Terrorism Reference Center & EBSCOHost; Open Source Center \\
MEDLINE (through Web of Knowledge portal) & Thomson Reuters, PNNL Library \\
Military \& Government Collection & EBSCOHost; Open Source Center \\
Oceanic Abstracts & ProQuest; PNNL Library \\
Scirus & \\
\hline Scopus & EBSCOHost; Open Source Center \\
Water Resources Abstracts & ProQuest; PNNL Library \\
Web of Science (Science edition), Conference Proceedings Citation & Thomson Reuters, PNNL Library \\
Index (Science; Social Sciences \& Humanities) & \\
\hline
\end{tabular}


The agents, pathogens and toxins listed in Appendix B were combined with additional keywords (Table 2.2) to refine search results. An example search string: [one disease, toxin, agent, pathogen from Appendix $\mathrm{C}$ and all its synonyms (Boolean Operator OR linking the synonyms together)] AND [one or more keywords from Table 2.2]. The dates were limited to 01-01-2011 to the date that the search was executed. Methods of truncation, search limiters, etc. used were dependent upon the database requirements. In some cases it was useful to refine the search results with the NOT Boolean Operator to exclude extraneous citations focused on AIDS, HIV, STD, cancers, etc. The resulting relevant literature was downloaded into EndNote X6 bibliographic management software for portability, ease of use, export capability, and document storage solutions.

Table 2.2. Additional Keywords Used to Refine and Identify Biosurveillance Modeling Literature

\begin{tabular}{|c|c|}
\hline \multicolumn{2}{|c|}{ Search Terms and Phrases } \\
\hline Adulteration and food & Early recognition \\
\hline Adulteration and pharmaceuticals & Epidemic model* \\
\hline $\begin{array}{l}\text { Biolog* or pathogen or toxin or disease model } \\
\text { characterization }\end{array}$ & Event detection and biolog* or pathogen or toxin \\
\hline Biological risk assessment & Event detection biosurveillance \\
\hline Biosurveillance & Event-based biosurveillance \\
\hline "Biosurveillance intelligence" & $\begin{array}{l}\text { Foodborne disease* detection or surveillance or } \\
\text { outbreak }\end{array}$ \\
\hline Bioterror* agents & Forecast + GIS or GPS or remote sensing \\
\hline Bioterror* and model & Geodemographics \\
\hline Bioterror* food model & Geoinformatics biosurveillance \\
\hline CBRN model* & Geosurveillance \\
\hline Communicable disease detection or model* & Global biosurveillance \\
\hline Crop disease model $*$ & Global surveillance \\
\hline Disease and weather forecast & Health intelligence \\
\hline Disease detection & Health security \\
\hline Disease epidemic & "Infectious disease" surveillance or model* \\
\hline Disease forecast & Insect risk + model \\
\hline Disease forecast* model & Model +predictive, + probabilistic,+ projection,+ forecast \\
\hline Disease indicators and/or warnings & Outbreak prediction \\
\hline Disease management & Outbreak forecast* \\
\hline Disease map* & $\begin{array}{l}\text { Pathogen detection/recognition/surveillance/prediction + } \\
\text { model* }\end{array}$ \\
\hline Disease modeling & Population dynamic* and outbreak \\
\hline Disease or bioterror* risk & $\begin{array}{l}\text { Predict* or project* or forecast* or "early warn*" or } \\
\text { "early detect*" and model* }\end{array}$ \\
\hline Disease or outbreak origin & Predictive model \\
\hline Disease outbreak or emergence or spread or transmission & Predictive model $^{*}$ and disease + infectious + epidemic \\
\hline Disease patterns & $\begin{array}{l}\text { Remote sensing and disease and/or forecast and/or } \\
\text { model }\end{array}$ \\
\hline Disease regulation & Risk map* and disease model* \\
\hline Disease risk or forecast or detection & Sentinel surveillance \\
\hline Disease simulation & Social disruption and disease or pathogen or toxin \\
\hline
\end{tabular}


Table 2.2. (contd)

\begin{tabular}{ll}
\hline & Search Terms and Phrases \\
\hline Disease source & $\begin{array}{l}\text { Social networks, social network analysis and } \\
\text { biosurveillance }\end{array}$ \\
Disease surveillance and infectious & Spatial analysis disease \\
Disease transmission & Spatial disease model* \\
Disease warning & Spatial epidemiology \\
Drug contamination or surveillance or outbreak & Surveillance or security \\
Early detection & Syndromic surveillance \\
& Vector borne (or vector-borne) disease model
\end{tabular}

After each database in Table 2.1 was searched, a batch export of the citations with abstracts was generated in Microsoft Word ${ }^{\circledR}$. The citations were evaluated by SMEs for potential to contain predictive or forecasting models focused on biosurveillance. Relevant abstracts were flagged with a color: green for Yes, yellow for Maybe. Abstracts that lacked a clear relevance to the research effort were not flagged. Each citation batch was vetted twice, with the first pass conducted by a postdoctoral scientist and the second pass was conducted by a research staff scientist with expertise in epidemiology or microbiology. If the SME disagreed with the initial assessment, the SME judgment was accepted.

Once the batch assessments were complete, the results were reviewed by the data analyst. The data analyst created Group folders (Yes, Maybe, No) in each database's respective EndNote library and moved each citation to the appropriate folder based on the assessment completed in the previous step. Literature in the Yes and Maybe categories were acquired in PDF format. Once these materials were received, the PDF files were stored with the citation in the EndNote database.

The literature citations were prepared for import into Drupal, the web-based content management platform used by BioCat. All of the flagged Yes citations from each database EndNote library were copied into a new library file. Because of the overlap between abstracting/indexing coverage in major scientific databases, duplicate records were identified and removed. The same process was applied to the Maybe citations. This effort resulted in master EndNote libraries consisting of only those citations that met our newly vetted evaluation metrics criteria. Each of these libraries was imported into Drupal separately. As the Yes citations were imported, they were tagged Yes $(n=447)$. As the Maybe citations were imported, they were tagged Maybe $(n=1383)$. The citations that lacked a clear relevance to the research effort were not imported to BioCat $(n=26,824)$.

After the previous steps were completed, a prioritized list of agents was requested from NBIC. From the 281 unique pathogens, toxins, and agents extracted from the nine priority lists (see Appendix B and Appendix C), the client provided PNNL with a smaller subset list of sixteen prioritized agents. These agents are those for which the NBIC has pressing information needs (see Appendix D). Using this smaller prioritized list of agents, the PNNL team queried the EndNote database to identify all of the citations matching these agents and meeting the Yes criteria $(n=96)$. See Section 3.0 for detailed description of the model evaluation process and results. 


\subsection{Model Evaluations}

This work was conducted in part to characterize published models that are capable of predicting disease events in order to determine opportunities for expanded research and to define operational readiness levels. Ultimately, practitioners need to be able to access and then operate these models without significant reprogramming. The model's forecasts or predictions need to have a known precision or error rate. An operationally ready model must also be mature. The PNNL team has expended a significant effort to address this last requirement. In partnership with the Los Alamos National Laboratory (LANL), a set of metrics was developed that enhance the attributes of biosurveillance models that PNNL co-authored during the Phase 1 BioCat project. The LANL team was qualified to contribute to developing the model metrics through their leadership in a Defense Threat Reduction Agency-sponsored effort to evaluate biosurveillance data sources. Over the course of three virtual meetings, the PNNL and LANL teams derived evaluation metrics to be used to assess disease models. The result of the discussions led to the PNNL team developing multiple metrics organized into three levels with each tier requiring greater domain knowledge in order to complete the evaluation. The metrics we recommend are enumerated in Appendix E, Disease Forecast and Prediction Model Evaluation Metrics \& Definitions.

Given the potential importance of these models to global health security, it is essential to develop a categorization scheme that defines a model's viability for use in an operational setting. none exists, but one possibility is illustrated in the following discussion, based upon the readiness level" (TRL) originally developed by NASA. ${ }^{1}$ NASA TRL levels were not designed to apply to modeling and simulation, much less biosurveillance models, so the definitions require modification. An initial modification of these definitions is shown in

Table 3.1. In such a scheme, the models are characterized based on how the model was validated, what type of data was used to validate the model, and the validity of data used to create the model.

Currently, the verification and validation $(\mathrm{V} \& \mathrm{~V})$ of predictive models, regardless of realm of application, is an area that requires better definition and techniques. The results of model $\mathrm{V} \& \mathrm{~V}$ can be used in the definition of model operational readiness; however, the readiness level definitions must also be accompanied by data validation, uncertainty quantification, and model fitness-for-use evaluations, many of which are areas of active research. Clarity in the definition of readiness levels and the criteria to achieve upper levels will enable confidence in the ability to consistently assign readiness levels to models and lead to enhanced value to decision makers. Further development of the operational readiness level definitions and assignment criteria for disease prediction models are needed in order to evaluate the usefulness of this approach in an operational environment. Public health analysts and decision makers are in need of evidence-based guidance and the value of operational readiness levels for the models on which they depend cannot be overstated. PNNL recommends rigorous investigation to fully outline the criterion for each of the proposed operational readiness levels defined in

Table 3.1. It is also recommended that the viability of a particular model should be assessed through analytical case studies before its use in an operational setting.

\footnotetext{
${ }^{1}$ Mankins JC. 1995. Technology Readiness Levels A White Paper. Advanced Concepts Office, Office of Space Access and Technology, National Aeronautics and Space Administration.
} 
Table 3.1. Initial Definitions of Operational Readiness Levels for Disease Prediction Models

\begin{tabular}{ll}
\hline Level & Definition \\
\hline 1 & $\begin{array}{l}\text { Research only reported on observed information } \\
\text { A constructed model which has yet to be applied to data (or The model theory has been developed } \\
\text { based on observed or hypothesized information) }\end{array}$ \\
3 & $\begin{array}{l}\text { The model has been created but has not been validated } \\
\text { The model has been verified and validated }\end{array}$ \\
5 & $\begin{array}{l}\text { The model has been demonstrated as useful but for only its original location (pathogen or population) } \\
\text { and is still being adjusted }\end{array}$ \\
6 & $\begin{array}{l}\text { The model has been demonstrated as useful in both its original location (pathogen or population) as } \\
\text { well as an independent location (pathogen or population) }\end{array}$ \\
$7 \ldots \mathrm{n}$ & $\begin{array}{l}\text { Further study is needed to explicitly delineate the criterion for additional Technology Readiness } \\
\text { Levels }\end{array}$ \\
\hline
\end{tabular}

As revealed in Section 2.0, NBIC identified sixteen prioritized agents of interest (Appendix D). Using this list in conjunction with the papers that met our SME requirements, we identified 96 papers ready for evaluation. Based on time and staffing constraints, Web of Science and Google Scholar were used to identify the number of times these articles were cited since publication. The articles with post-publication citations $(n=61)$ were considered candidates for evaluation. Twenty-four articles were fully evaluated and curated in BioCat using the new evaluation metrics (Appendix E). These articles and the evaluation metrics are discussed in Section 3.0.

Table 3.2. Client Priority Agent List

\begin{tabular}{lccc}
\hline \multicolumn{1}{c}{ Agent } & No. of Articles & $\begin{array}{c}\text { No. Articles with } \\
\text { Citations }\end{array}$ & No. Evaluated \\
\hline Bacillus anthracis & 4 & 0 & 0 \\
Botulinum toxin & 0 & 0 & 0 \\
Burkholderia mallei & 0 & 0 & 0 \\
Burkholderia pseudomallei & 0 & 0 & 0 \\
Chlorpyrifos (Dursban) & - & - & - \\
Citrus Greening; Huanglongbing (HLB) of & 0 & 0 & 0 \\
citrus; Candidatus liberibacter americanus & & & - \\
Endosulfan & - & - & 2 \\
Foot and Mouth Disease (FMD) & 13 & 6 & 1 \\
Francisella tularensis & 2 & 1 & 16 \\
Influenza (pandemic) & 52 & 35 & 0 \\
Ralstonia solanacearum & 0 & 0 & 0 \\
Rinderpest virus & 0 & 0 & 0 \\
SARS & 8 & 7 & 2 \\
Variola (major and minor) & 3 & 2 & 3 \\
Viral hemorrhagic fevers including Ebola and & 6 & 4 & 0 \\
Marburg & & & $\mathbf{2 4}$ Evaluated \\
\hline Yersinia pestis & 8 & 6 & \\
\hline \multicolumn{1}{c}{ Total YES citations } & $\mathbf{9 6}$ Articles & $\mathbf{6 1}$ with Citations & \\
\hline
\end{tabular}


The following are the citations for the 24 articles that were fully evaluated.

\section{Influenza, pandemic}

Araz, OM, et al. 2011, "A Simulation Model for Policy Decision Analysis: A Case of Pandemic Influenza on a University Campus." Journal of Simulation 5(2):89-100.

Araz, OM, et al. 2012, "Simulation Modeling for Pandemic Decision Making: A Case Study with BiCriteria Analysis on School Closures.” Decision Support Systems 55(2):564-75.

Baker, PRA, et al. 2011, "Epidemiologic Modeling with Flusurge for Pandemic (H1N1) 2009 Outbreak, Queensland, Australia.” Emerging Infectious Diseases 17(9):1608-14.

Dorigatti, I, et al. 2012, “A New Approach to Characterising Infectious Disease Transmission Dynamics from Sentinel Surveillance: Application to the Italian 2009-2010 A/H1N1 Influenza Pandemic.” Epidemics 4(1):9-21.

Gupta, SD, et al. 2011, "Modeling of H1N1 Outbreak in Rajasthan: Methods and Approaches." Indian Journal of Community Medicine 36(1):36-38.

Inaida, S, et al. 2011, "Geographic Trends and Spread of the Pandemic (H1N1) 2009 in the Metropolitan Areas of Japan Studied from the National Sentinel Data.” Japanese Journal of Infectious Diseases 64(6):473-81.

Jin, Z, et al. 2011, "Modelling and Analysis of Influenza A (H1N1) on Networks.” BMC Public Health 11(Suppl 1): 59.

Lee, VJ, et al. 2011, "Comparability of Different Methods for Estimating Influenza Infection Rates over a Single Epidemic Wave.” American Journal of Epidemiology 174(4):468-78.

Lee, VJ, et al. 2011, “A Clinical Diagnostic Model for Predicting Influenza among Young Adult Military Personnel with Febrile Respiratory Illness in Singapore.” PLoS ONE 6(3): e17468.

Loganathan, P, et al. 2011, "Towards Forecasting Flu Dynamics Using a Regionalized State Space Model.” In International Symposium on Advanced Control of Industrial Processes, ADCONIP 2011, pp. 175-80.

Matrajt, L, and IM Longini, Jr. 2012, "Critical Immune and Vaccination Thresholds for Determining Multiple Influenza Epidemic Waves.” Epidemics 4(1):22-32.

Nishiura, H, G Chowell, and C Castillo-Chavez. 2011, "Did Modeling Overestimate the Transmission Potential of Pandemic (H1N1-2009)? Sample Size Estimation for Post-Epidemic Seroepidemiological Studies." PloS ONE 6(3): e17908.

Rios-Soto, KR, B Song, and C Castillo-Chavez. 2011, "Epidemic Spread of Influenza Viruses: The Impact of Transient Populations on Disease Dynamics." Mathematical Biosciences and Engineering 8(1):199-222. 
Sharomi, O, et al. 2011, "Modelling the Transmission Dynamics and Control of the Novel 2009 Swine Influenza (H1n1) Pandemic.” Bulletin of Mathematical Biology 73(3): 515-548.

Smieszek, T, et al. 2011, "Reconstructing the 2003/2004 H3n2 Influenza Epidemic in Switzerland with a Spatially Explicit, Individual-Based Model.” BMC Infectious Diseases 11:115.

Torres, SF, et al. 2012, "High Mortality in Patients with Influenza A pH1N1 2009 Admitted to a Pediatric Intensive Care Unit: A Predictive Model of Mortality." Pediatric Critical Care Medicine 13(2): e78-e83.

\section{Francisella tularensis}

Rydén, P, et al. 2012, “Outbreaks of Tularemia in a Boreal Forest Region Depends on Mosquito Prevalence.” Journal of Infectious Diseases 205(2):297-304.

\section{Foot and Mouth Disease}

Dion, E, L VanSchalkwyk, and EF Lambin. 2011, "The Landscape Epidemiology of Foot-and-Mouth Disease in South Africa: A Spatially Explicit Multi-Agent Simulation.” Ecological Modelling 222(13):2059-72.

Sanson, RL, et al. 2011, "Foot and Mouth Disease Model Verification and 'Relative Validation' through a Formal Model Comparison.” Revue scientifique et technique (International Office of Epizootics) 30(2):527-40.

\section{Variola}

Fuller, T, et al. 2011, "Using Remote Sensing to Map the Risk of Human Monkeypox Virus in the Congo Basin.” EcoHealth 8(1):14-25.

McKinley, TJ, et al. 2013, In Press, "Simulation-Based Bayesian Inference for Epidemic Models." Computational Statistics and Data Analysis.

\section{Viral Hemorrhagic Fevers}

Gale, P, et al. 2012, "Impact of Climate Change on Risk of Incursion of Crimean-Congo Haemorrhagic Fever Virus in Livestock in Europe through Migratory Birds." Journal of Applied Microbiology 112(2):246-57.

Medeiros, LCdC, et al. 2011, "Modeling the Dynamic Transmission of Dengue Fever: Investigating Disease Persistence.” PLoS Neglected Tropical Diseases 5(1):e942.

Wei, L, et al. 2011, "Using Geographic Information System-Based Ecologic Niche Models to Forecast the Risk of Hantavirus Infection in Shandong Province, China." American Journal of Tropical Medicine and Hygiene 84(3):497-503. 
After the 24 articles were evaluated, the PNNL SMEs (one epidemiologist and one microbiologist) identified several papers with distinctive or significant methodology or research conclusions. These papers are summarized in the following bullets.

- Inaida et al. (2011) applied kriging to influenza-like illness data to produce smoother spatial estimates of influenza incidence.

- Araz et al. (2011) evaluated the efficacy of social distancing and other mitigation practices for influenza transmission on a university campus, based on the campus response plan. They performed sensitivity analysis of the model parameters to identify the primary drivers of the changes in transmission.

- Dion et al (2011) performed a landscape analysis of cattle-buffalo contact near Kruger National Park in South Africa. Although not directly modeling foot and mouth disease, the identification of areas of greater likelihood for cattle-buffalo contact may serve as a proxy estimate of disease transmission risk. In the sensitivity analysis of the model parameters, they included two-way interaction terms.

- Gale et al. (2011) predicted and forecast the geographic spread of Crimean-Congo hemorrhagic fever, taking into account the impact of bird and tick populations in disease movement.

- Wei et al. (2011) do an excellent job clearly describing the model, the input data (source of input data), as well as type of data being fed into the model (e.g., continuous versus categorical). The high transparency of the model (not so clear in other publications) makes it possible for others to provide an independent verification and validation of the predictions and forecasts made in the publication.

\subsection{BioCat 2.0 Website}

BioCat has been developed and managed as a web-based system to maximize access by end users. Using a content management system was an important first step, because it allowed the use of existing code development and technology to create a structure for the website. The use of a content management system also enabled easy to use search and organization of information stored in the BioCat database. Login-based user permissions limit access and view/edit privileges.. Since the initial development of the BioCat website, the needs and implementation of the website have evolved, as described in this section.

\subsection{Needs and Limitations of the BioCat 1.0 Website}

In the first version of BioCat, Semantic MediaWiki (SMW) was the content management system. This system enables protecting the BioCat information from individuals who have not specifically been granted access. However, SMW also brought a number of limitations and challenges. The team wanted to have the ability to give different users permission to edit only certain parts of the information. SMW only allows someone to edit all the information or none of it. The team also wanted to track which users were editing what information and to enable the evaluation of models in an organized workflow (explained later). SMW did not support these functions. 


\subsection{Updating Software to Meet the Needs of BioCat 2.0}

Given the limitations presented by SMW, a new content management system was sought for BioCat 2.0. The development team suggested another web-based content management platform called Drupal. Like SMW, Drupal is open source software, meaning that it is free to download and use. The open source model enables developers to constantly collaborate to update, fix and expand Drupal features and capabilities. As a result Drupal has a greater capacity for growth, variety and the ability to meet a far wider range of uses.

\subsubsection{Benefits of the Drupal Web-Based Content Management Platform}

Drupal has the benefit of being well supported and widely used. It has been adopted as a favorite among content management systems, especially in the U.S. government, including DHS. The community that has been built around Drupal allows collaboration, support, and development among hundreds of thousands of developers with different skill sets and experience. Drupal allows the development of new website add-on features that work with the original system, and those features can then be shared and used by others. Drupal is powerful enough to make many different features possible on a website, so Drupal is well positioned to support future BioCat development if needed.

One add-on feature that is already implemented in BioCat is called "Biblio." Biblio is a bibliography tool for the management and display of lists of scholarly publications. It supports a number of formats when importing, exporting, or displaying the publications information, including BibTex, which was the format used for BioCat publications. Biblio also handles formatting directly on the webpages, so we can display it in APA, Chicago, and many other scholarly publication formats. This is handled by Drupal directly, rather than requiring the information to be manually entered in all the desired formats.

Drupal enables greater flexibility and control over user access and editing privileges. Different users can be access different content areas, rather than all or none. ifferent users access to change only certain parts of content, rather than all or none. Drupal also tracks how much work has been completed. These options allow BioCat to have a workflow in which individuals with different levels of knowledge can review specific content according to their permissions and then pass it on to the next person in a multistage review process that more efficiently uses different levels of expertise.

\subsubsection{Implementation of Publications Review Workflow for BioCat}

The "workflow" concept for BioCat was implemented in Drupal. The publication review process has been divided into multiple defined levels of review, each of which must be performed before an evaluation is considered complete. Once the publications are imported, they are deemed "Level 1." At Level 1, interns completed the preliminary information. If the publication cannot be reviewed for some reason, for example if it is in a language no one can read, it is marked as "cannot evaluate," and it will be removed from the workflow. If they are unsure about any information that they have filled in, the document can be flagged as needing a second look, which notifies upper-level reviewers to double check the inputted information. Publications deemed to be neither an event prediction nor an event forecast model are removed from the workflow when the Level 1 review is marked complete. All other completed Level 1 publications progress to Level 2 review. 
In Level 2, additional information is entered about the model. As in Level 1, a second look may be requested if there is uncertainty regarding the review. Once the Level 2 review is marked complete, it passes to Level 3. In Level 3, SMEs add additional information to complete the review. Once the publication review is marked as complete the publication is removed from the workflow.

Each of these Levels has a web page listing all the publications that are in that Level, so anyone with access to those workflow levels can readily view the publications in the respective workflows. There are also pages to list publications that are completed, closed, unable to be evaluated, and needing second looks. This enables anyone in the workflow process to quickly identify tasks and access the relevant publications.

A user registration process is used to control access to the BioCat site and to the workflow levels. Users must create an account and be logged in before seeing any content on the website. In addition, accounts also must be approved, which enables to the ability to allow or deny each user's access. In addition to controlling site access, user registration enables tracking who uses and edits the site. Without user registration, there is no way to track this in formation. Moreover, content interactions and changes can be tracked; it is possible to revert content to an earlier version if necessary and to identify which user(s) is responsible if the site is misused.

Each user account can have its own set of permissions that determine what the user can see or change with great granularity (e.g., a publication date). Certain groups of people can be given similar sets of permissions. In BioCat, all users with an approved account can see any publications. Users with the corresponding permissions can edit citations. Users whose account is marked as Level 1 can only see the Level 1 workflow pages, and can only add/edit Level 1 review information. Users with Level 2 accounts can see and edit Levels 1 and 2, while Level 3 users can see and edit information at all three levels.

\subsubsection{Site Administration Features}

Site administrators can see and edit all workflow levels and can edit any part of a publication being reviewed. In addition, there are a number of pages with access restricted only to administrators. One of these pages contains user information and enables administrators to see all the accounts for the website. In addition to a list of users, demographics are also provided, including charts displaying e-mail domain type and organization affiliation type. This information is collected as part of the account creation process. Site administrators also have access to pages that list what publications have been marked as closed, completed, or cannot be evaluated.

\subsubsection{Filtered Display of Content with Faceted Browsing}

For anyone viewing a list of all the publications on the site, one of the most helpful tools that Drupal enables us to implement is "faceted browsing". Faceted browsing filters a publications list and displays only those publications that meet user-selected criteria. ${ }^{2}$ Normally, the list of publications that any logged-in user can see simply shows every publication on the website. A user looking for a specific publication would need to search for it, which means they would need to know some part of its name. However, users may often be looking for certain types of publications, not necessarily a particular one. Or

\footnotetext{
${ }^{2}$ Stefaner, M. (2009). Dynamic Taxonomies and Faceted Search: Theory, Practice and Experience. New York, NY, Springer .
} 
they may not know exactly what publication they are looking for, but they may know certain things about it, such as what year it was published or what type of publication it is. With Drupal, publication information can be evaluated and the information that might matter to a browsing user can be expressed as content criteria. We can provide these content criteria as options (facets) next to the list. When a user selects their criteria of interest, the publication list automatically updates to show only publications that match those criteria. For example, if someone only wants to view publications that are conference papers, they simply select "Conference paper" under the "Filter by Publication Type" facet. The list will then show only conference papers, eliminating the need to browse through the full publication list looking for only conference papers.

\subsubsection{Current Software for BioCat 2.0 Website}

The following are Linux server requirements for BioCat as it has been built in Drupal:

- A minimum of $15 \mathrm{MB}$ of disk space (60 MB preferred) for the installation, more for the database

- Apache, Nginx, or Microsoft IIS (server software)

- MySQL 5.0.15 or higher with PHP data objects (PDO), PostgreSQL 8.3 or higher with PDO, SQLite 3.3.7 or higher (open source database)

- PHP 5.2.5 or higher (scripting and programming language)

- Drush (a command line shell and scripting interface for Drupal)

- PHP modules: mod rewrite, apc, curl, GD library, ImageMagick, MB String, ldap, mysql, mssql, pear, xml serializer. 


\subsection{Visual Tour of the BioCat 2.0 Website}

An unregistered site visitor cannot log in and does not have access to any content on the BioCat website. The only links available to visitors are to register/login, to contact us, or to use the DHS navigation at the bottom of the page.

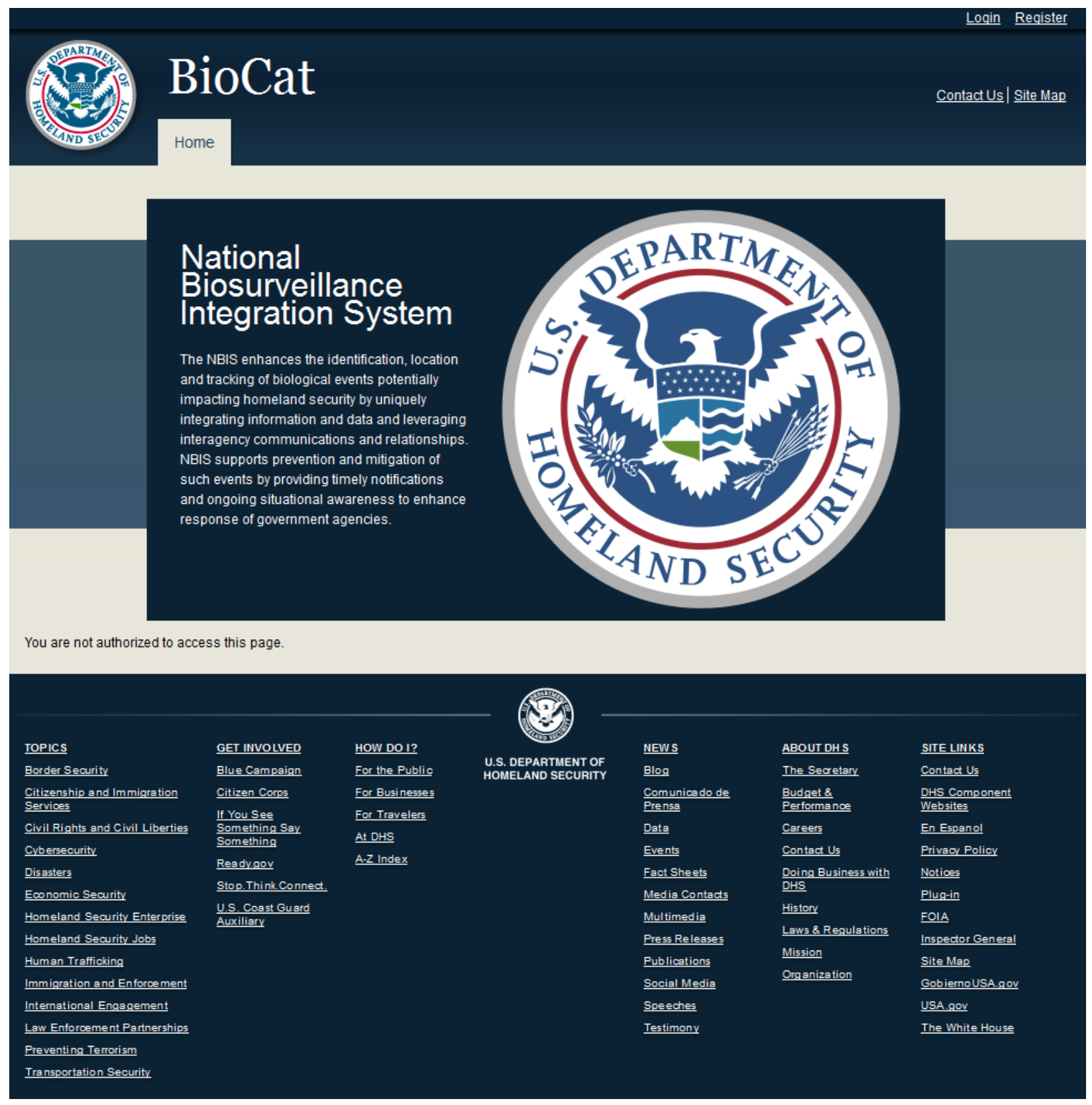

What an Unregistered Visitor to BioCat Sees 
On the registration page, BioCat collects a username and email, as well as some preliminary information about the user. The registration must be approved by someone with administrative privileges on the website, who assigns a role to the new user before the user can log in and use the website.

\section{User account}

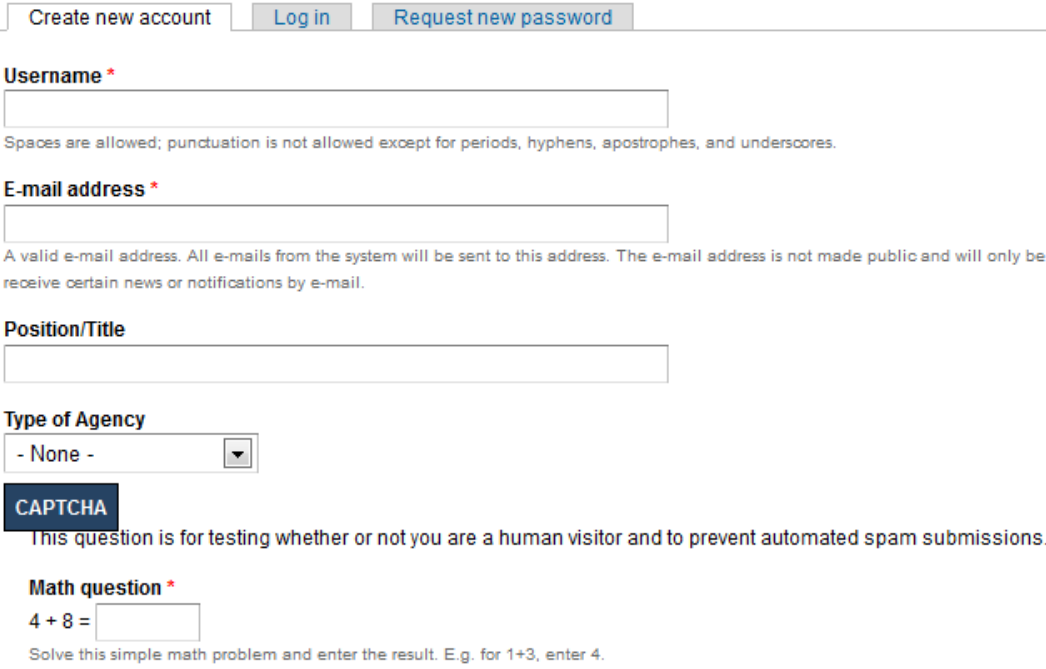

Registration Page for New User Accounts

Once users have an account and can log in, access to the site is based on the user roles that each user has been assigned by the site administrator. In the example here, a general user now has the option at the top of the page to view publications, as well as the ability to search the website.

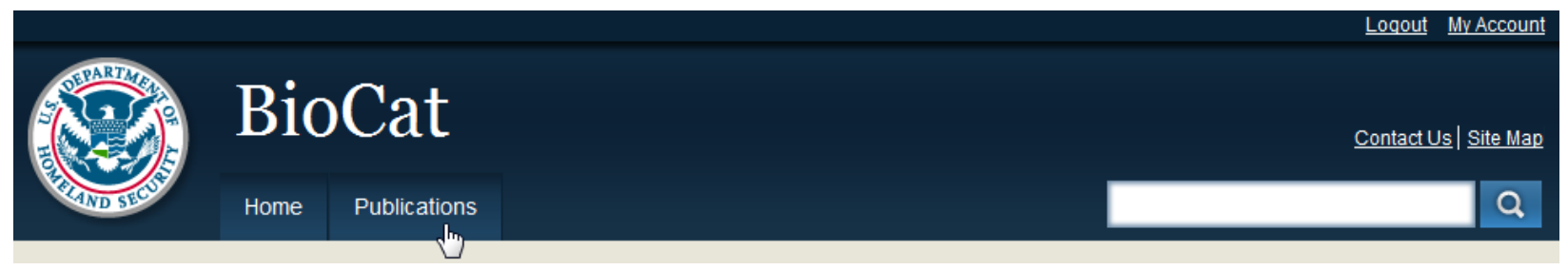

Publications List and Search Options Available to General Users 
The publications page lists a short summary of all the publications on the site. In addition to the titles, the page lists authors, keywords, and the titles of the publication from which each publication was taken. By default, the page lists all the publications alphabetically, 50 entries at a time.

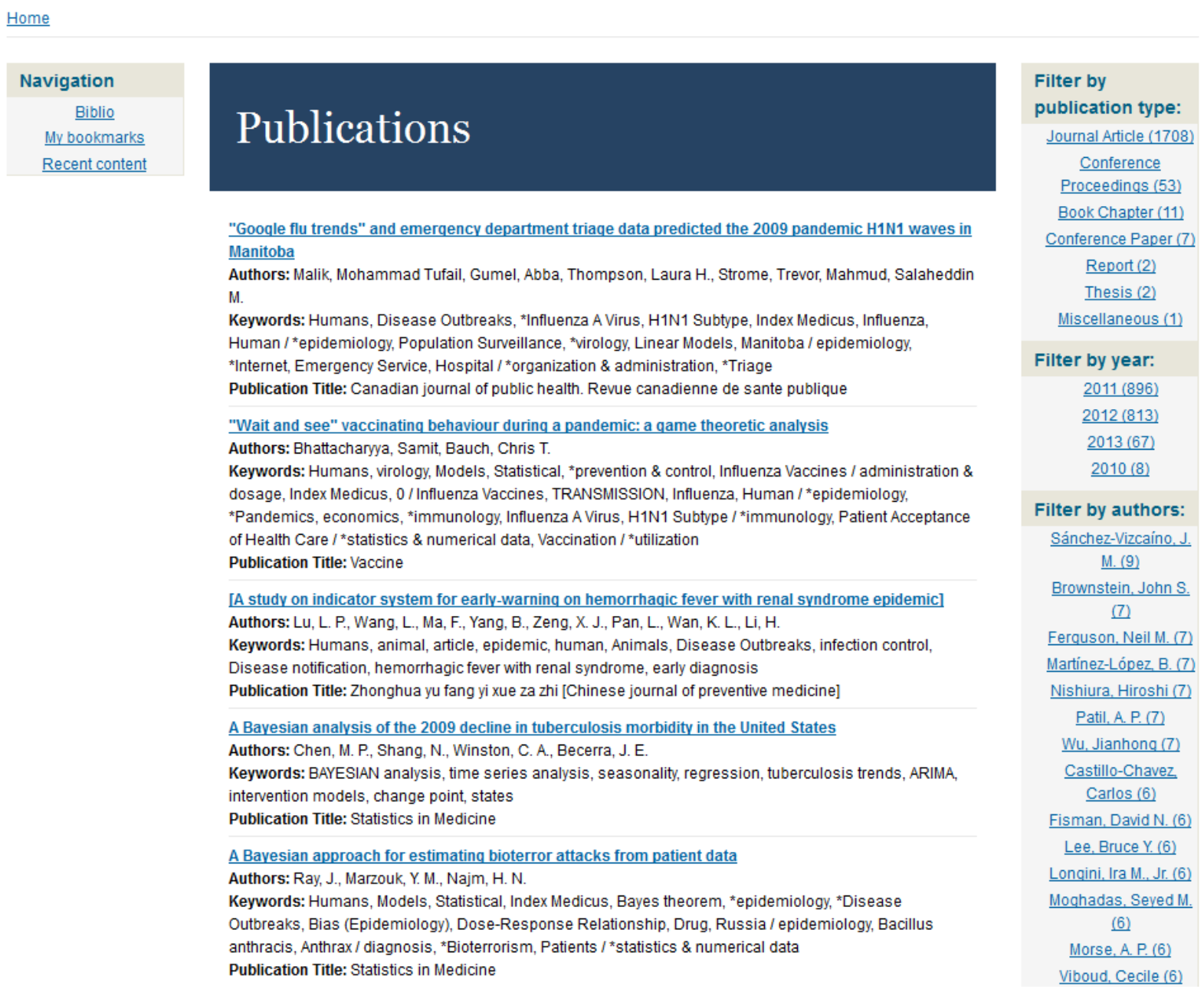

"Google flu trends" and emergency department triage data predicted the 2009 pandemic H1N1 waves in Manitoba

Authors: Malik, Mohammad Tufail, Gumel, Abba, Thompson, Laura H., Strome, Trevor, Mahmud, Salaheddin M.

Keywords: Humans, Disease Outbreaks, *Influenza A Virus, H1N1 Subtype, Index Medicus, Influenza, Human / *epidemiology, Population Surveillance, *virology, Linear Models, Manitoba / epidemiology,

*Internet, Emergency Service, Hospital / *organization \& administration, ${ }^{*}$ Triage

Publication Title: Canadian journal of public health. Revue canadienne de sante publique

"Wait and see" vaccinating behaviour during a pandemic: a qame theoretic analysis Authors: Bhattacharyya, Samit, Bauch, Chris T.

Keywords: Humans, virology, Models, Statistical, " prevention \& control, Influenza Vaccines / administration \& dosage, Index Medicus, 0 / Influenza Vaccines, TRANSMISSION, Influenza, Human / *epidemiology,

${ }^{*}$ Pandemics, economics, *immunology, Influenza A Virus, H1N1 Subtype / *immunology, Patient Acceptance

of Health Care / *statistics \& numerical data, Vaccination / *utilization

Publication Title: Vaccine

[A study on indicator system for early-warning on hemorrhaqic fever with renal syndrome epidemic] Authors: Lu, L. P., Wang, L., Ma, F., Yang, B., Zeng, X. J., Pan, L., Wan, K. L., Li, H.

Keywords: Humans, animal, article, epidemic, human, Animals, Disease Outbreaks, infection control,

Disease notification, hemorrhagic fever with renal syndrome, early diagnosis

Publication Title: Zhonghua yu fang yi xue za zhi [Chinese journal of preventive medicine]

A Bavesian analysis of the 2009 decline in tuberculosis morbidity in the United States Authors: Chen, M. P., Shang, N., Winston, C. A., Becerra, J. E.

Keywords: BAYESIAN analysis, time series analysis, seasonality, regression, tuberculosis trends, ARIMA

intervention models, change point, states

Publication Title: Statistics in Medicine

A Bavesian approach for estimating bioterror attacks from patient data

Authors: Ray, J., Marzouk, Y.M., Najm, H. N.

Keywords: Humans, Models, Statistical, Index Medicus, Bayes theorem, *epidemiology, *Disease

Outbreaks, Bias (Epidemiology), Dose-Response Relationship, Drug, Russia / epidemiology, Bacillus

anthracis, Anthrax / diagnosis, *Bioterrorism, Patients / ${ }^{*}$ statistics \& numerical data

Publication Title: Statistics in Medicine

\section{Publications Page with Default Alphabetical Listing and Filtering Criteria Options}

Criteria on the right side of the publications list enable users to narrow their search via faceted browsing. Each of these criteria list some of the most common results for each category. The exact number of list entries in that category are listed in parentheses after it. For example, if someone only wanted to see conference papers, they would select conference paper under Publication Type: 


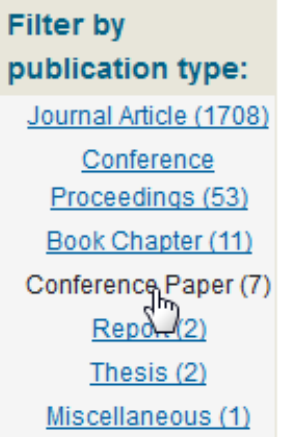

Choosing to Filter the Publications List by Conference Paper Publication Type

The page will update according to what criteria the user chooses as a search filter. In this case, the page reloads to show only those seven conference papers, eliminating the need to search through all the entries for this single publication type.

Home . Conference Paper

Navigation

Biblio

My bookmarks

Recent content

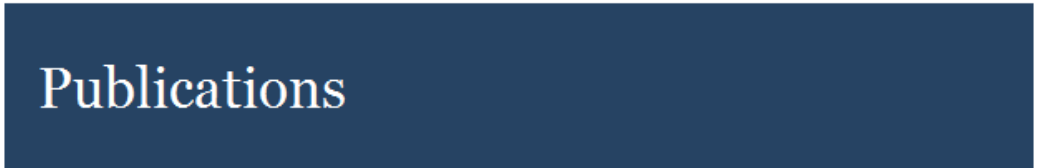

Denque surveillance based on a computational model of spatio-temporal locality of Twitter Authors: Gomide, J, Celoso, A, Meira, W, Almeida, V, Benevenuto, F, Ferraz, F, Teixeira, M. G. Publication Title: ACM WebSci'11 (June 14-17, 2011)

Experimental study on modified model of indoor bio-aerosol dispersion Authors: Yan, D., Tian, Z., Neng, Z

Keywords: Atmospheric aerosols, Forecasting, infectious disease, particulate matter, Bacteria, Technology, Experimental studies, Dispersions, Manufacture, Airflow pattern, Bacteria emanating experiment,

Bio-aerosol, Continuous point-source dispersion model, Airflow patterns, Bioaerosols, Control methods, Dispersion models, Indoor environment, Modified model, Office environments, Transmission route, Under floor air supply, Atmospheric movements, Experiments

Publication Title: 2011 International Conference on Manufacturing Science and Technology, ICMST 2011

Modeling and simulation for the spread of H1N1 influenza in school usinq artificial societies Authors: Cao, Z., Duan, W., Ge, Y., Qiu, X

Keywords: Public Health, Computer simulation, Risk management, Information science, Students, Emergency Management, H1N1 Influenza, Modeling and Simulation, Public Health Security, Agent model, Artificial societies, Emergency measures, Environment models, Hebei Province, Role-based, Simulation experiments, Social relationships, School buildings

Publication Title: Pacific Asia Workshop on Intelligence and Security Informatics, PAISI 2011

Modeling infection with multi-agent dynamics

Authors: Dong, W., Heller, K., Pentland, A.

Keywords: Dynamics, Health risks, Random processes, Epidemic models, human dynamics, living lab,

multi-agent modeling, stochastic process, Cellular Phone, Discrete-time, Multi-Agent Model, Potential risks,

Small population, Spread of an infection, Cellular telephones, Mobile phones

Publication Title: 5th International Conference on Social Computing, Behavioral-Cultural Modeling and

Prediction, SBP 2012

Modelling to contain pandemic influenza A (H1N1) with stochastic membrane systems: A work-inprogress paper

Authors: Xu, L

Keywords: Computer simulation, Intervention strategy, infectious disease, pandemic influenza, Stochastic systems, bioinformatics, Decision makers, Mitigation strategy, membrane computing, pandemic influenza $A$ (H1N1), pandemic spread modelling, stochastic membrane systems, Ecological systems, Membrane
Current search

Search found 7 items

$(-)$ Conference Paper

Filter by

publication type:

$(-)$ Conference Paper

Filter by year:

2011 (4)

2012 (3)

Filter by authors:

Almeida, V (1)

Benevenuto, $F$ (1)

Bi. J. (1)

Cao. Z. (1)

Celoso, A(1)

Dong. W. (1)

Duan. W. (1)

Ferraz, $F(1)$

Ge. Y. (1)

Gomide, J (1)

Heller. K. (1)

Meira. W(1)

Nenq. Z. (1)

Pentland, A. (1)

Qiu, X. (1)

Shi. M. W. (1)

Teixeira, M. G. (1)

Tian, Z. (1)

Wu. Q. (1)

Xu. L. (1)

Publications List Filtered by Conference Paper Publication Type 
If the user selects one of the publications, BioCat will display a page that shows more details about it. General users will only be able to see the publication information. Here the user has selected the first publication on the previous list. Note that the links at the bottom allow the user to search Google Scholar for this publication, or to add it as a bookmark so that the user can look it up quickly on the My bookmarks page (linked in the left navigation) later when revisiting BioCat.

Home $» \underline{\text { Publications }}$

Navigation

Biblio

My bookmarks

Recent content

\section{Dengue surveillance based on a computational} model of spatio-temporal locality of Twitter

\begin{tabular}{|c|c|}
\hline $2013-07-25$ & :40 - DrupalSysop \\
\hline Title & Dengue surveillance based on a computational model of spatio-temporal locality of Twitter \\
\hline $\begin{array}{l}\text { Publication } \\
\text { Type }\end{array}$ & Conference Paper \\
\hline $\begin{array}{l}\text { Year of } \\
\text { Publication }\end{array}$ & 2011 \\
\hline Authors & Gomide J, Celoso A, Meira W, Almeida V, Benevenuto F, FerrazF, Teixeira M.G \\
\hline $\begin{array}{l}\text { Conference } \\
\text { Name }\end{array}$ & ACM WebSci'11 (June 14-17, 2011) \\
\hline $\begin{array}{l}\text { Conference } \\
\text { Location }\end{array}$ & Koblenz, Germany \\
\hline Abstract & $\begin{array}{l}\text { Twitter is a unique social media channel, in the sense that users discuss and talk about the most diverse topics, } \\
\text { including their health conditions. In this paper we analyze how Dengue epidemic is re ected on Twitter and to what } \\
\text { extent that information can be used for the sake of surveillance. Dengue is a mosquito-borne infectious disease } \\
\text { that is a leading cause of illness and death in tropical and subtropical regions, including Brazil. We propose an } \\
\text { active surveillance methodology that is based on four dimensions: volume, location, time and public perception. } \\
\text { First we explore the public perception dimension by performing sentiment analysis. This analysis enables us to } \\
\text { Iter out content that is not relevant for the sake of Dengue surveillance. Then, we verify the high correlation } \\
\text { between the number of cases reported by ocial statistics and the number of tweets posted during the same time } \\
\text { period (i.e., R2 }=0: 9578 \text { ). A clustering approach was used in order to exploit the spatiotemporal dimension, and } \\
\text { the quality of the clusters obtained becomes evident when they are compared to ocial data (i.e., Randlndex = } \\
0: 8914 \text { ). As an application, we propose a Dengue surveillance system that shows the evolution of the dengue } \\
\text { situation reported in tweets, which is implemented in www.observatorio.inweb.orq.br/denquel. }\end{array}$ \\
\hline
\end{tabular}

Google Scholar Add Bookmark

Example of Publication Information for One Publication 
If a user has been approved as a member of the review workflow, the user will also be able to see more details about the publication, particularly about how the review process has been filled out so far.

\section{Level 1}

Disease Specific

The causative agent of the event being modelled is disease specific.

Yes

Agent/Pathogen/Toxin/Pest

The agent(s)/pathogen(s)/toxin(s)/pest(s) of the event being modelled.

Influenza

Event Prediction

The model predicts the future occurrence of an eventoutbreak.

Yes

Event Forecast

The model makes estimations about the future progress or behavior of an occurring event/outbreak.

No

Verified or Validated

First pass identification of whether or not the model has been verified and/or validated.

Yes

\section{Level 2}

Corresponding Author

The article's corresponding author as identified in the full-text document.

Vernon Lee

Model Creation Year

The year the model was created.

2010-01-01 00:00:00

Population (Species) Affected Identified

The specific affected population/species identified and modelled in the article.

Yes

Type of Validation and Verification

The method used to verify and/or validate the model's maturity

Specificity and Sensitivity (verification)

In Use in an Operational Environment

The model is in use in an operational environment

No

\section{Level 3}

\section{Accessibility}

The degree to which and mechanism by where the model is made available, e.g., plug-and-play, downloadable, etc.

Run Time, Complexity, Capabilities Required

Characteristics required for executing the model effectively.

Input Geography

Geographic area attributes used as model input.

Local

nutnut fenaranhu

Workflow Information View Accessible to Authorized Review Editors

This workflow information is only accessible to those users who have been selected as editors. In addition, they are only able to see and perform review of publications in levels at or below their appointed role. 
Here is shown the workflow view options in the BioCat menu for a person who is part of Level 2 review. (Note that the Pending Review options may appear on this menu when publications in those levels have been flagged as needing a second look.)

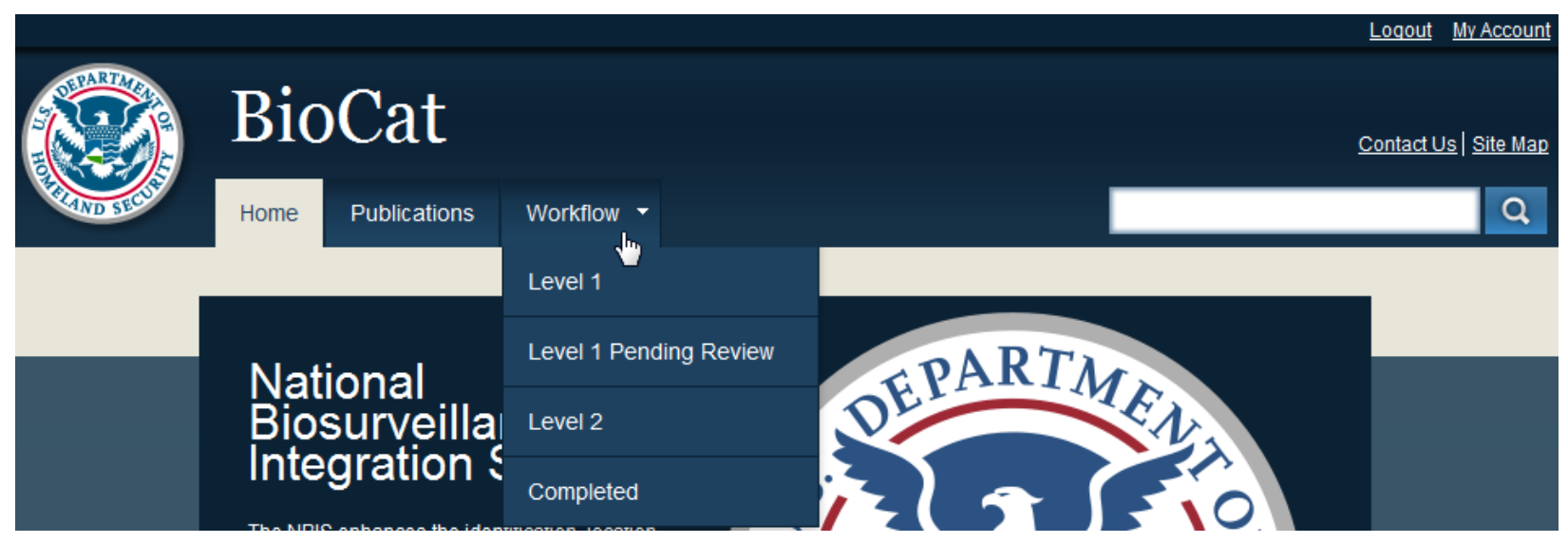

Workflow Menu Visible to Authorized Review Editors (Example) 
Each of the workflow view pages on the Workflow menu list publications that are currently in the corresponding level of workflow. For example, the Level 2 editors can see below all the publications that are ready for them to review on the Level 2 page. They can click on the title to see the previously shown detailed view of the publication, or select Review to begin their review.

Home $\$$ Workflow

Navigation
$\frac{\text { Add content }}{\underline{\text { Biblio }}}$
$\frac{\text { My bookmarks }}{\text { Recent content }}$

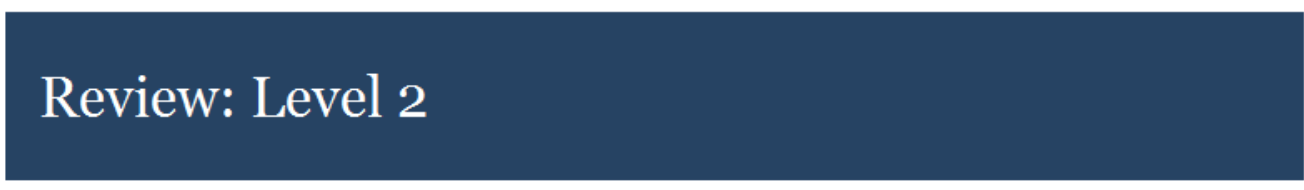

Title

Apply

Reset

$\begin{array}{ll}\text { Title } & \text { Updated } \\ \text { date }\end{array}$

A mathematical model to distinquish sociological and biological susceptibility factors in disease $\quad 08 / 01 / 13$

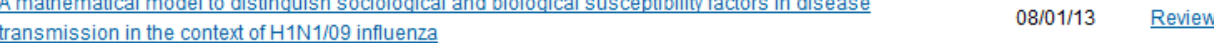

A new methodology for estimating contagious biological agent casualties as a function of time $\quad 08 / 01 / 13 \quad \underline{\text { Review }}$

An individual-based simulation of pneumonic plaque transmission following an outbreak and the $\quad 08 / 01 / 13 \quad \underline{\text { Review }}$

significance of intervention compliance

Analysinq the spatial patterns of livestock anthrax in Kazakhstan in relation to environmental factors: a $\quad 07 / 26 / 13 \quad$ Review

comparison of local $\left(\mathrm{G}(\mathrm{i})^{\star}\right)$ and morphology cluster statistics

Attempted early detection of influenza A(H1N1) pandemic with surveillance data of influenza-like illness and $\quad 07 / 31 / 13 \quad \underline{\text { Review }}$

unexplained pneumonia

Determinants of the incidence of hand, foot and mouth disease in China usinq geographically weighted $\quad 07 / 26 / 13 \quad$ Review

rearession models

Development of a resource modelling tool to support decision makers in pandemic influenza preparedness: 08/02/13 Review

The AsiaFluCap Simulator

Excess mortality associated with influenza A and B virus in Honq Konq. 1998-2009 $\quad 08 / 02 / 13 \quad \underline{\text { Review }}$

Foot and mouth disease revisited: re-analysis usinq Bavesian spatial susceptible-infectious-removed $\quad 07 / 26 / 13 \quad \underline{\text { Review }}$

H3N2v and Other Influenza Epidemic Risk Based on Age-Specific Estimates of Sero-Protection and Contact

Network Interactions $\quad 08 / 01 / 13$

08/01/13 Review

$\underline{I m p a c t}$ of weekday social contact patterns on the modeling of influenza transmission, and determination of $\quad 08 / 02 / 13 \quad \underline{\text { Review }}$

the influenza latent period

Likely effectiveness of pharmaceutical and non-pharmaceutical interventions for mitiqatinq influenza virus
transmission in Monqolia

\begin{tabular}{lll} 
Modelinq Disease Spreadinq on Complex Networks & $08 / 02 / 13$ & $\underline{\text { Review }}$ \\
\hline Multivariate Bavesian modelinq of known and unknown causes of events_An application to biosurveillance & $07 / 26 / 13$ & $\underline{\text { Review }}$
\end{tabular}

Dreling

Workflow View Page for a Level 2 Review Editor 
Upon selecting the Review option for a specific publication, users can add/change information up to their level of permission. For example, a Level 2 user can edit Level 1 data and enter Level 2 data but cannot see or edit level 3 data.
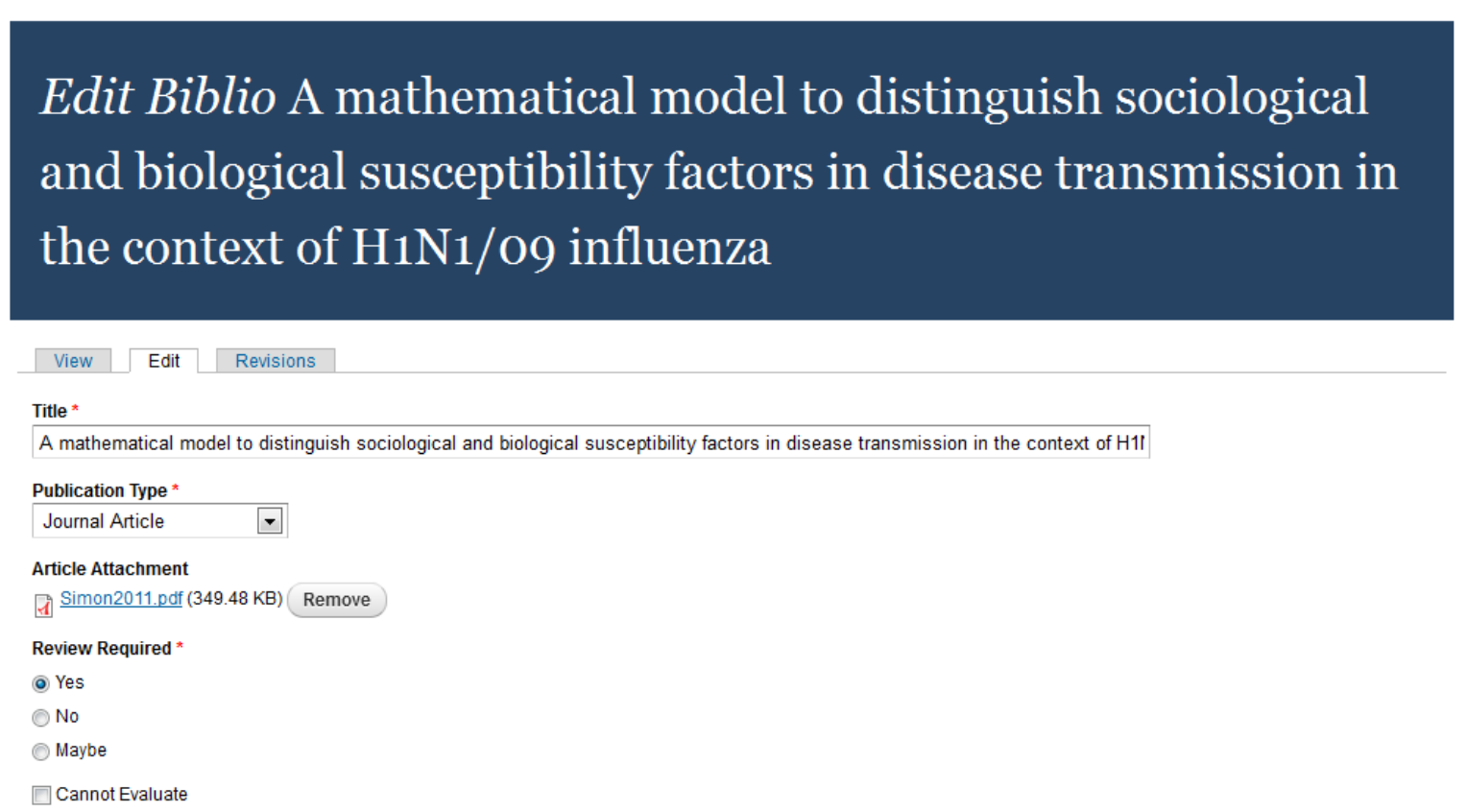

Example Form for Editing One Publication by a Level 2 Editor

The user can then save current information, flag it for a second-look review, or mark it as ready for the next level of review. Depending on the criteria previously stated, the workflow tool on the website will organize it according to its level, or take it out of the workflow process if it has been completed or closed. 
Users that have been selected as BioCat administrators can see any level of the workflow and access the workflow views through the Workflow menu as shown here. They also have another option on the general menu, User Admin.

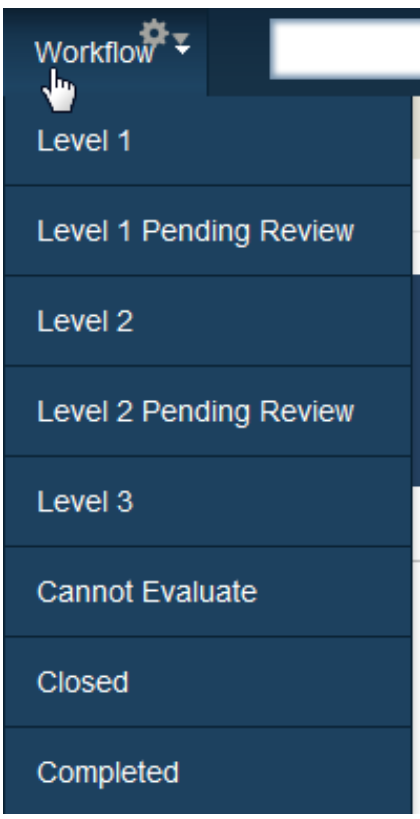

Workflow Menu with a Full Set of Review Options

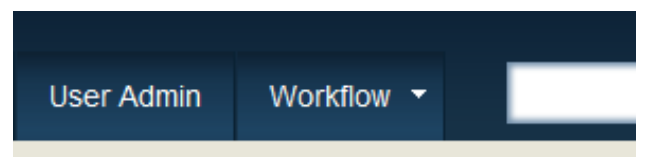

User Admin Option on the BioCat Menu

The user administration view page allows administrators to see a list of the users that have been registered on the site.

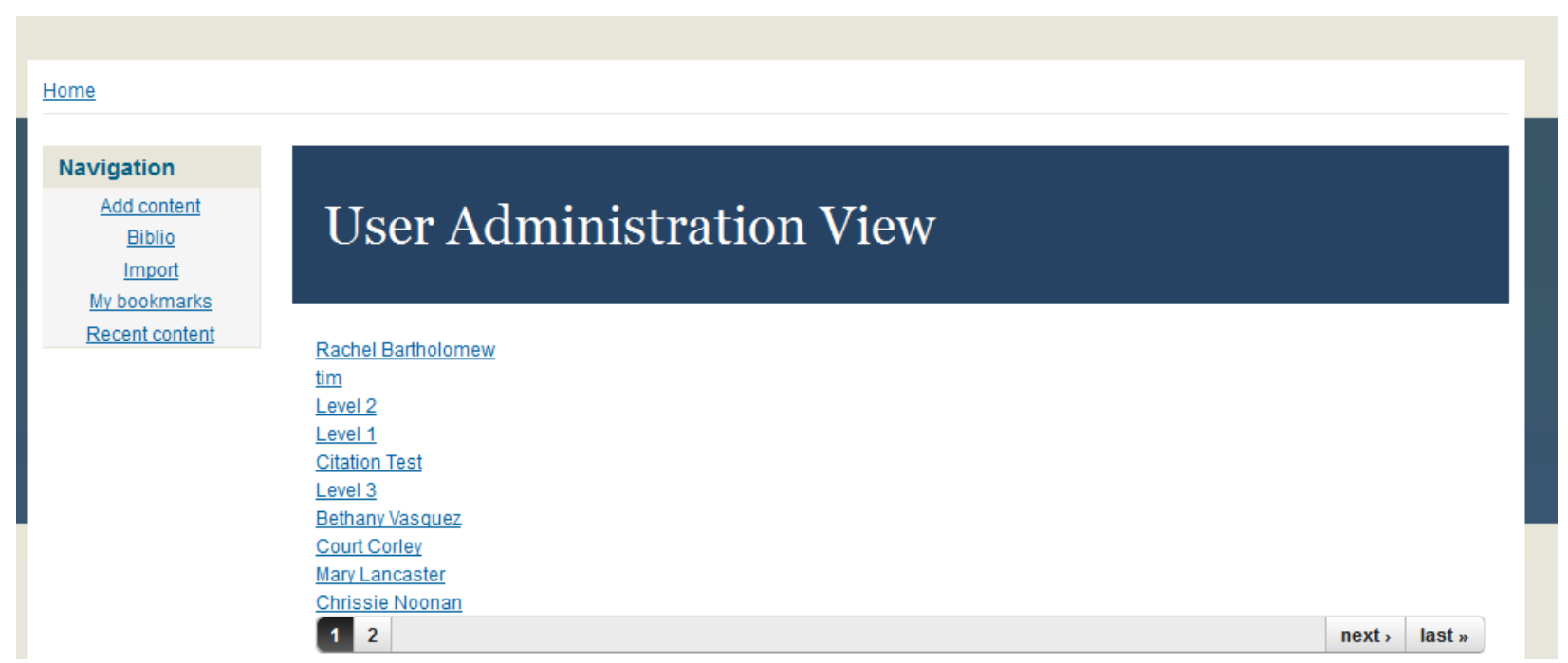

User Administration View Page (Example) 
In addition, the user administration view page also lists statistics and charts about the users, automatically gathered by the site when users are registered.

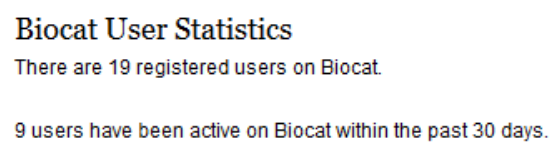

Biocat Users by Agency

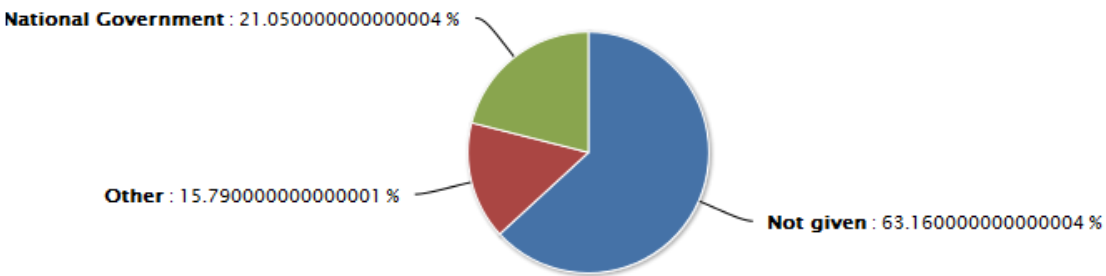

Biocat Users by E-mail Domain

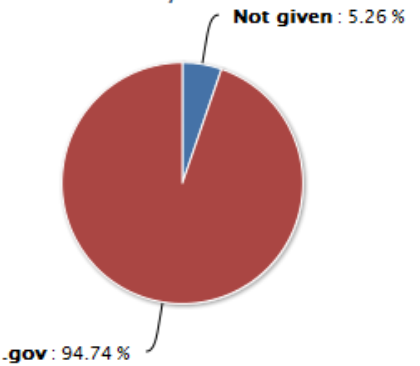

Biocat Users by Institution/Affiliation

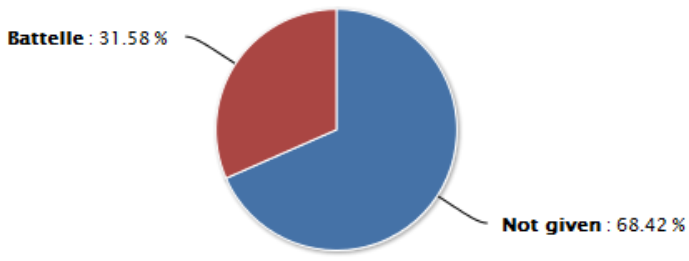

User Statistics Charts for All the Users of the BioCat Website

\subsection{Future Work}

\subsection{Integration of BioCat 1.0 into BioCat 2.0}

Future funding efforts will enable the PNNL team to merge data collected in the first phase of research with the current work. This is a multi-step process that could be accomplished in either of two ways. The first path would consist of importing the literature citations from the first year effort into the new Drupal-based BioCat website. This can be completed relatively quickly with a small investment of funds and staffing. Literature citations would be migrated from EndNote X4 to EndNote X6 and then exported for ingestion into BioCat. The result would be that the new BioCat website would contain all the literature citations of the Phase 1 implementation, including those that may not be of confirmed interest. 
The second path would be more in line with this year's efforts. The proposed first step would be to conduct a vetting process of the literature using the newly established assessment metrics, importing only those citations that survive the vetting and then evaluating a subset based on NBIC's priority list (Appendix D).

\subsection{Enabling BioCat Accessibility on Mobile Devices}

Another development direction that will likely prove useful for future use is mobile-compatible web design. Currently, the site is only made to display properly when viewed with a larger screen, such as on a desktop computer. When viewed at the smaller resolutions necessary for a tablet or phone, certain elements of the page do not display correctly, and the size of the webpage requires those with small devices to scroll left and right in addition to scrolling up and down. With additional development, the site would be adapted to automatically adjust to the width of the viewing device and to display the information in the most appropriate format according to the device being used. This would be a very helpful feature from the perspective of both users and administrators.

\subsection{Additional Drupal Development Features}

In addition to enabling mobile access, Drupal also supports additional features for development that could be useful to the BioCat user base. Examples of these features include multilingual capabilities and automatic content ingestion. Multilingual capabilities allow for the integration of more than one language into the website. This integration may be done through the navigation of the site, within the content of the site, or both. Automatic content ingestion enables Drupal to visit selected websites and social media sources, then extract content from those sources into BioCat. This could be a good way to discover new articles, refresh general site content from DHS or other agencies, or even monitor social media or other sources for mentions of topics and keywords of interest.

As time goes on, the Drupal community at large will continue to release new versions of the content manager. Ongoing maintenance of BioCat is critical to both management of day-to-day functionality and site security. The migration of BioCat into Drupal 8 (the next, developing version of Drupal) should be explored as that technology matures. This strategy will give BioCat access to significantly re-engineered features and new capabilities and it will keep the site current with the rest of the Drupal development and implementation community.

Finally, as users interact with BioCat, it is likely that additional "views" of the data will be requested to improve user work processes and to address user needs. Examples of existing views can be found on the various Workflow pages or the publications page. Examples of new views might include additional visualizations of publication information, reports, raw data for integration with other applications, or content workflow updates. 


\section{Appendix A}

\section{Biosurveillance Modelers and Stakeholders}

The following table provides contact information and websites of the experts and research institutions that were identified as focused on the topic of biosurveillance. 
Biosurveillance Modelers and Stakeholders

\begin{tabular}{|c|c|c|c|c|c|c|c|}
\hline Name & Agency & Division & Email & Phone & Address & Position & Website(s) \\
\hline $\begin{array}{l}\text { Anderson, Sir Roy } \\
\text { M }\end{array}$ & $\begin{array}{l}\text { Imperial College } \\
\text { London }\end{array}$ & $\begin{array}{l}\text { School of Public } \\
\text { Health }\end{array}$ & $\begin{array}{l}\text { roy.anderson@imp } \\
\text { erial.ac.uk }\end{array}$ & $44(0) 2075943399$ & $\begin{array}{l}\text { G22, Norfolk } \\
\text { Place, St. Mary's } \\
\text { Campus }\end{array}$ & $\begin{array}{l}\text { Chair in Infectious } \\
\text { Disease } \\
\text { Epidemiology }\end{array}$ & \\
\hline Anyamba, Assaf & NASA & $\begin{array}{l}\text { Goddard Earth } \\
\text { Sciences } \\
\text { Technology Center } \\
\text { at NASA's } \\
\text { Goddard Space } \\
\text { Flight Center }\end{array}$ & $\begin{array}{l}\text { Assaf.Anyamba@n } \\
\text { asa.gov }\end{array}$ & (301) 614-6601 & $\begin{array}{l}\text { NASA Goddard } \\
\text { Building 33, Room } \\
\text { G308 } \\
\text { NASA GSFC, } \\
\text { Code } 618 \\
\text { Greenbelt, MD } \\
20771 \text { USA }\end{array}$ & $\begin{array}{l}\text { Associate Research } \\
\text { Scientist }\end{array}$ & $\begin{array}{l}\text { http://gimms.gsfc.n } \\
\text { asa.gov/ }\end{array}$ \\
\hline Arthur, Ray & $\mathrm{HHS} / \mathrm{CDC}$ & $\begin{array}{l}\text { Global Disease } \\
\text { Detection } \\
\text { Operations Center }\end{array}$ & $\begin{array}{l}\text { rca8@cdc.gov; } \\
\text { ray.arthur@cdc.hhs } \\
\text {.gov }\end{array}$ & (404) 639-3855 & Atlanta, Georgia & Director & \\
\hline $\begin{array}{l}\text { Barrett, } \\
\text { Christopher L. }\end{array}$ & Virginia Tech & $\begin{array}{l}\text { Virginia } \\
\text { Bioinformatics } \\
\text { Institute }\end{array}$ & $\begin{array}{l}\text { cbarrett@vbi.vt.ed } \\
\text { u }\end{array}$ & (540) 231-1745 & $\begin{array}{l}\text { Research Building } \\
\text { XV } \\
\text { Virginia Tech } \\
\text { Blacksburg, VA } \\
24061 \text { USA }\end{array}$ & $\begin{array}{l}\text { Director of } \\
\text { Network Dynamics } \\
\text { and Simulation } \\
\text { Science Laboratory }\end{array}$ & $\begin{array}{l}\text { http://ndssl.vbi.vt.e } \\
\text { du/people/cbarrett. } \\
\text { html }\end{array}$ \\
\hline $\begin{array}{l}\text { Bartrand, Timothy } \\
\text { A. }\end{array}$ & $\begin{array}{l}\text { Tetra Tech Clancy } \\
\text { Environmental } \\
\text { Consultants, Drexel } \\
\text { University }\end{array}$ & $\begin{array}{l}\text { Environmental } \\
\text { Information } \\
\text { Services Group }\end{array}$ & $\begin{array}{l}\text { tab32@drexel.edu; } \\
\text { tbartrand@clancye } \\
\text { nv.com }\end{array}$ & (610) 668-9227 & $\begin{array}{l}109 \text { Llanfair Rd } \\
\text { Bala Cynwyd, PA } \\
19004 \text { USA }\end{array}$ & $\begin{array}{l}\text { Environmental } \\
\text { Engineer, Visiting } \\
\text { research assistant } \\
\text { professor }\end{array}$ & \\
\hline Beardsley, Kristine & FBI & $\begin{array}{l}\text { Bioterrorism } \\
\text { Prevention } \\
\text { Program in the } \\
\text { Weapons of Mass } \\
\text { Destruction } \\
\text { Directorate }\end{array}$ & $\begin{array}{l}\text { kristine.beardsley } \\
\text { @ic.fbi.gov }\end{array}$ & & & $\begin{array}{l}\text { Supervisory } \\
\text { Special Agent }\end{array}$ & \\
\hline Beckham, Tammy & Texas A\&M & $\begin{array}{l}\text { Texas Veterinary } \\
\text { Medical Diagnostic } \\
\text { Laboratory }\end{array}$ & $\begin{array}{l}\text { trbeckham@ag.tam } \\
\text { u.edu; } \\
\text { tbeckham@tvmdl.t } \\
\text { amu.edu }\end{array}$ & $979-845-2855$ & $\begin{array}{l}1500 \text { Research } \\
\text { Parkway, Ste. } 130 \\
\text { College Station, } \\
\text { TX } 77845\end{array}$ & $\begin{array}{l}\text { Director of } \\
\text { Department of } \\
\text { Homeland } \\
\text { Security's Center of } \\
\text { Excellence for } \\
\text { Foreign Animal } \\
\text { and Zoonotic } \\
\text { Diseases (FAZD } \\
\text { Center) }\end{array}$ & \\
\hline
\end{tabular}


Biosurveillance Modelers and Stakeholders

\begin{tabular}{|c|c|c|c|c|c|c|c|}
\hline Name & Agency & Division & Email & Phone & Address & Position & Website(s) \\
\hline Blackburn, Jason & $\begin{array}{l}\text { University of } \\
\text { Florida }\end{array}$ & $\begin{array}{l}\text { Emerging } \\
\text { Pathogens Institute }\end{array}$ & $\begin{array}{l}\text { jkblackburn@ufl.e } \\
\underline{\mathrm{du}}\end{array}$ & $352-392-0494$ & $\begin{array}{l}\text { Emerging } \\
\text { Pathogens Institute } \\
\text { University of } \\
\text { Florida, } \\
\text { Gainesville, FL }\end{array}$ & & \\
\hline Boghossian, Aida & USDA & DOD/NCMI & $\begin{array}{l}\text { aboghossian@ncmi } \\
\text {.detrick.army.mil }\end{array}$ & $301-619-8539$ & $\begin{array}{l}\text { Ft Detrick, } \\
\text { Frederick, MD }\end{array}$ & USDA/APHIS rep & \\
\hline Boots, Mike & $\begin{array}{l}\text { University of } \\
\text { Exeter, UK }\end{array}$ & $\begin{array}{l}\text { Centre for Ecology } \\
\text { and Conservation, } \\
\text { College of Life and } \\
\text { Environmental } \\
\text { Sciences }\end{array}$ & $\begin{array}{l}\text { m.boots@exeter.ac. } \\
\text { uk }\end{array}$ & $\begin{array}{l}44(0) 132625 \\
5735\end{array}$ & $\begin{array}{l}\text { Daphne du Maurier } \\
\text { Centre for Ecology } \\
\text { and Conservation } \\
\text { College of Life and } \\
\text { Environmental } \\
\text { Sciences } \\
\text { University of } \\
\text { Exeter, Cornwall } \\
\text { Campus } \\
\text { TR10 9 EZ } \\
\text { UK }\end{array}$ & $\begin{array}{l}\text { Professor of } \\
\text { Disease Biology }\end{array}$ & $\begin{array}{l}\text { http://people.exeter } \\
\text {.ac.uk/mb437/ }\end{array}$ \\
\hline Bright, Patti & $\begin{array}{l}\text { Department of the } \\
\text { Interior }\end{array}$ & $\begin{array}{l}\text { Contaminant } \\
\text { Biology Program }\end{array}$ & pbright@usgs.gov & $703-648-4238$ & & $\begin{array}{l}\text { Acting USGS } \\
\text { Contaminant } \\
\text { Biology Program } \\
\text { Coordinator }\end{array}$ & \\
\hline $\begin{array}{l}\text { Buckeridge, David } \\
\text { L. }\end{array}$ & $\begin{array}{l}\text { University Clinic - } \\
\text { Royal Victoria } \\
\text { Hospital, Canada }\end{array}$ & $\begin{array}{l}\text { Department of } \\
\text { Epidemiology, } \\
\text { Biostatistics and } \\
\text { Occupational } \\
\text { Health }\end{array}$ & $\begin{array}{l}\text { david.buckeridge@ } \\
\text { mcgill.ca }\end{array}$ & $\begin{array}{l}\text { 514-934-1934 Ext. } \\
32991\end{array}$ & $\begin{array}{l}\text { Pine } 1140 \\
1140 \text { avenue des } \\
\text { Pins Ouest } \\
\text { Montreal H3A 1A3 } \\
\text { Quebec } \\
\text { Canada }\end{array}$ & Associate Professor & $\begin{array}{l}\text { http://surveillance. } \\
\text { mcgill.ca/index.ht } \\
\text { ml }\end{array}$ \\
\hline Butel, Mike & DoD & $\begin{array}{l}\text { Global Health } \\
\text { Surveillance }\end{array}$ & $\begin{array}{l}\text { Michael.Butel@ha. } \\
\text { osd.mil }\end{array}$ & & $\begin{array}{l}\text { U.S. Department of } \\
\text { Defense } \\
\text { Arlington, VA }\end{array}$ & $\begin{array}{l}\text { NIWG Principal, } \\
\text { Assistant Secretary } \\
\text { of Defense (Health } \\
\text { Affairs) }\end{array}$ & \\
\hline
\end{tabular}


Biosurveillance Modelers and Stakeholders

\begin{tabular}{|c|c|c|c|c|c|c|c|}
\hline Name & Agency & Division & Email & Phone & Address & Position & Website(s) \\
\hline Capela, Ruben & $\begin{array}{l}\text { Universidade da } \\
\text { Madeira, Portugal }\end{array}$ & $\begin{array}{l}\text { Department of } \\
\text { Biology \& Geology }\end{array}$ & rcapela@uma.pt & $\begin{array}{l}351291705002 \\
\text { ext } 5380\end{array}$ & $\begin{array}{l}\text { Department of } \\
\text { Biology \& } \\
\text { Geology, } \\
\text { Universidade da } \\
\text { Madeira, Campus } \\
\text { Universitario da } \\
\text { Penteada, 9000 } \\
\text { Funchal, Madeira, } \\
\text { Portugal. }\end{array}$ & Professor & \\
\hline $\begin{array}{l}\text { Carter-Foster, } \\
\text { Nancy }\end{array}$ & $\begin{array}{l}\text { U.S. Department of } \\
\text { State }\end{array}$ & Health Affairs & $\begin{array}{l}\text { FosterNC@state.go } \\
\text { v }\end{array}$ & (202) 647-2435 & $\begin{array}{l}2201 \text { "C" Street, } \\
\text { Northwest } \\
\text { Washington, D.C. } \\
20520 \text { USA }\end{array}$ & Senior advisor & \\
\hline Chen, Mark L. & $\begin{array}{l}\text { National University } \\
\text { of Singapore }\end{array}$ & $\begin{array}{l}\text { Saw Swee Hock } \\
\text { School of Public } \\
\text { Health }\end{array}$ & $\begin{array}{l}\text { mark_ic_chen@tts } \\
\text { h.com.sg }\end{array}$ & (65) 63577317 & $\begin{array}{l}11 \text { Jalan Tan Tock } \\
\text { Seng Clinical } \\
\text { Epidemiology } \\
\text { Singapore } 308433\end{array}$ & $\begin{array}{l}\text { Consultant } \\
\text { Epidemiologist }\end{array}$ & \\
\hline Clarke, Neville & Texas A\&M & $\begin{array}{l}\text { Foreign Animal } \\
\text { and Zoonotic } \\
\text { Disease Defense }\end{array}$ & n-clarke@tamu.edu & (979) 845-2855 & & Director & $\begin{array}{l}\text { http://fazd.tamu.ed } \\
\text { u/ }\end{array}$ \\
\hline $\begin{array}{l}\text { Clements, Archie } \\
\text { C.A. }\end{array}$ & $\begin{array}{l}\text { University of } \\
\text { Queensland, } \\
\text { Herston, QLD, } \\
\text { Australia and } \\
\text { Queensland } \\
\text { Institute of Medical } \\
\text { Research, Herston, } \\
\text { QLD }\end{array}$ & $\begin{array}{l}\text { School of } \\
\text { Population Health } \\
\text { and Australian } \\
\text { Centre for } \\
\text { International and } \\
\text { Tropical Health }\end{array}$ & $\begin{array}{l}\text { a.clements@uq.edu } \\
\text {.au }\end{array}$ & 61-7-334-64706 & $\begin{array}{l}\text { Dr. Archie C A } \\
\text { Clements, School } \\
\text { of Population } \\
\text { Health, University } \\
\text { of Queensland, } \\
\text { Herston Road, } \\
\text { Herston, } \\
\text { Queensland, 4006, } \\
\text { Australia }\end{array}$ & $\begin{array}{l}\text { Associate } \\
\text { professor, head of } \\
\text { Infectious Disease } \\
\text { Epidemiology Unit }\end{array}$ & \\
\hline Codeco, Claudia T. & $\begin{array}{l}\text { Oswaldo Cruz } \\
\text { Foundation, Rio de } \\
\text { Janeiro, Brazil }\end{array}$ & $\begin{array}{l}\text { The Scientific } \\
\text { Computing } \\
\text { Program }\end{array}$ & $\begin{array}{l}\text { codeco@malaria.pr } \\
\text { occ.fiocruz.br; } \\
\text { codeco@ fiocruz.br; } \\
\text { codeco@icict.fiocr } \\
\text { uz.br }\end{array}$ & $55-21-598-4399$ & $\begin{array}{l}\text { Programa de } \\
\text { Computação } \\
\text { Científica/ } \\
\text { Fundação Oswaldo } \\
\text { Cruz } \\
\text { Av. Brasil, 4365, } \\
\text { Manguinhos } \\
\text { Rio de Janeiro, RJ, } \\
\text { Brasil, 21045-900 }\end{array}$ & $\begin{array}{l}\text { Associate } \\
\text { Researcher }\end{array}$ & \\
\hline Colwell, Rita & Johns Hopkins & Bloomberg School & rcolwell@jhsph.ed & $410-955-3720$ & 615 N. Wolfe & Distinguished & \\
\hline
\end{tabular}


Biosurveillance Modelers and Stakeholders

\begin{tabular}{|c|c|c|c|c|c|c|c|}
\hline Name & Agency & Division & Email & Phone & Address & Position & Website(s) \\
\hline & $\begin{array}{l}\text { University, Canon } \\
\text { US Life Sciences, } \\
\text { Inc. }\end{array}$ & $\begin{array}{l}\text { of Public Health, } \\
\text { Environmental } \\
\text { Health Sciences }\end{array}$ & $\mathrm{u}$ & & $\begin{array}{l}\text { Street } \\
\text { Baltimore, MD } \\
21205\end{array}$ & $\begin{array}{l}\text { Professor, } \\
\text { Chairman }\end{array}$ & \\
\hline Cooke, William H. & $\begin{array}{l}\text { Mississippi State } \\
\text { University }\end{array}$ & $\begin{array}{l}\text { GeoResources } \\
\text { Institute }\end{array}$ & $\begin{array}{l}\text { whc5@geosci.msst } \\
\text { ate.edu }\end{array}$ & $601-325-9479$ & $\begin{array}{l}\text { GeoResources } \\
\text { Institute } \\
\text { Box } 9652 \\
\text { Mississippi State, } \\
\text { MS } 39762\end{array}$ & $\begin{array}{l}\text { Associate } \\
\text { professor, research } \\
\text { scientist, interim } \\
\text { department head }\end{array}$ & \\
\hline Corcoran, Patrick & US Postal Service & $\begin{array}{l}\text { Dangerous Mail } \\
\text { Investigations }\end{array}$ & $\begin{array}{l}\text { PJCorcoran@uspis. } \\
\text { gov }\end{array}$ & & & $\begin{array}{l}\text { Inspector in } \\
\text { Charge for } \\
\text { Operational } \\
\text { Support }\end{array}$ & \\
\hline Craft, David L. & $\begin{array}{l}\text { Massachusetts } \\
\text { General Hospital } \\
\text { and Harvard } \\
\text { Medical School }\end{array}$ & $\begin{array}{l}\text { Department of } \\
\text { Radiation } \\
\text { Oncology and } \\
\text { Operations } \\
\text { Research Center }\end{array}$ & $\begin{array}{l}\text { dcraft@alum.mit.e } \\
\text { du; } \\
\text { dcraft@ partners.or } \\
\text { g }\end{array}$ & & $\begin{array}{l}\text { Massachusetts } \\
\text { General Hospital } \\
\text { Northeast Proton } \\
\text { Center - NPTC } \\
55 \text { Fruit St } \\
\text { Boston, MA } 02114\end{array}$ & Assistant Professor & \\
\hline Craigmile, Peter F. & $\begin{array}{l}\text { Ohio State } \\
\text { University, } \\
\text { University of } \\
\text { Glasgow, Scotland }\end{array}$ & $\begin{array}{l}\text { Department of } \\
\text { Statistics }\end{array}$ & $\begin{array}{l}\text { pfc@stat.osu.edu; } \\
\text { peter.craigmile@gl } \\
\text { asgow.ac.uk }\end{array}$ & & $\begin{array}{l}\text { School of } \\
\text { Mathematics and } \\
\text { Statistics } \\
\text { University Gardens } \\
\text { University of } \\
\text { Glasgow } \\
\text { Glasgow, G12 } \\
\text { 8QQ } \\
\text { United Kingdom }\end{array}$ & $\begin{array}{l}\text { Associate } \\
\text { Professor, Reader }\end{array}$ & $\begin{array}{l}\text { http://www.stats.gl } \\
\text { a.ac.uk/ pcraigmile } \\
\text { / }\end{array}$ \\
\hline Culotta, Aron & $\begin{array}{l}\text { Northeastern } \\
\text { Illinois University }\end{array}$ & $\begin{array}{l}\text { Department of } \\
\text { Computer Science }\end{array}$ & $\begin{array}{l}\text { A- } \\
\text { Culotta@neiu.edu }\end{array}$ & $\begin{array}{l}\text { (773) 442-4720 } \\
\text { (department) }\end{array}$ & $\begin{array}{l}5500 \text { N. St. Louis } \\
\text { Avenue } \\
\text { Chicago, IL } 60625\end{array}$ & Assistant Professor & $\begin{array}{l}\text { http://cs.neiu.edu/ } \\
\text { culotta }\end{array}$ \\
\hline Daszak, Peter & $\begin{array}{l}\text { EcoHealth } \\
\text { Alliance; } \\
\text { Columbia } \\
\text { University }\end{array}$ & $\begin{array}{l}\text { Center for Infection } \\
\text { and Immunity }\end{array}$ & $\begin{array}{l}\text { daszak@ecohealtha } \\
\text { lliance.org }\end{array}$ & $\begin{array}{l}212-380-4473 \\
815-365-8337\end{array}$ & $\begin{array}{l}460 \text { West 34th St, } \\
17 \text { th floor, New } \\
\text { York, NY 10001- } \\
2320\end{array}$ & $\begin{array}{l}\text { President and } \\
\text { Disease Ecologist, } \\
\text { adjunct professor }\end{array}$ & \\
\hline Dowling, Glenn & DOD/NCMI & & $\begin{array}{l}\text { gdowling@ncmi.de } \\
\text { trick.army.mil }\end{array}$ & & & & \\
\hline
\end{tabular}


Biosurveillance Modelers and Stakeholders

\begin{tabular}{|c|c|c|c|c|c|c|c|}
\hline Name & Agency & Division & Email & Phone & Address & Position & Website(s) \\
\hline Dubrawski, Artur & $\begin{array}{l}\text { Carnegie Mellon } \\
\text { University }\end{array}$ & Auton Lab & awd@cs.cmu.edu & (412) 268-6233 & $\begin{array}{l}\text { Carnegie Mellon } \\
\text { University } \\
\text { Auton Lab } \\
5000 \text { Forbes Ave } \\
\text { NSH } 3121 \\
\text { Pittsburgh, PA } \\
15213\end{array}$ & $\begin{array}{l}\text { Director (Auton } \\
\text { Lab), Systems } \\
\text { Scientist (Robotics } \\
\text { Institute), Adjunct } \\
\text { professor (Heinz } \\
\text { College) }\end{array}$ & $\begin{array}{l}\text { http://www.autonla } \\
\text { b.org/autonweb/10 } \\
\text { 223.html }\end{array}$ \\
\hline Eagle, Nathan & $\begin{array}{l}\text { MIT; txteagle Inc., } \\
\text { Northeastern } \\
\text { University, The } \\
\text { Santa Fe Institute, } \\
\text { Harvard University }\end{array}$ & $\begin{array}{l}\text { MIT Media Lab, } \\
\text { Department of } \\
\text { Epidemiology at } \\
\text { Harvard; Computer } \\
\text { Science at } \\
\text { Northeastern }\end{array}$ & $\begin{array}{l}\text { nathan@mit.edu; } \\
\text { eagle@ @sph.harvar } \\
\text { d.edu }\end{array}$ & $\begin{array}{l}857-776-3279 ; \\
(505) \text { 204-6637 }\end{array}$ & $\begin{array}{l}\text { MIT Design } \\
\text { Laboratory } \\
77 \text { Massachusetts } \\
\text { Ave } \\
\text { Bldg E15-383 } \\
\text { Cambridge MA } \\
02139 \\
\text { The Santa Fe } \\
\text { Institute } \\
1399 \text { Hyde Park Rd } \\
\text { Santa Fe, NM } \\
87501\end{array}$ & $\begin{array}{l}\text { CEO of txteagle, } \\
\text { Adjunct Assistant } \\
\text { Professor at } \\
\text { Harvard, visiting } \\
\text { assistant professor } \\
\text { at MIT Media lab, } \\
\text { research assistant } \\
\text { professor at } \\
\text { Northeastern, } \\
\text { Omidyar Fellow at } \\
\text { Santa Fe Institute }\end{array}$ & \\
\hline Eisen, Rebecca J. & $\mathrm{CDC}$ & $\begin{array}{l}\text { Division of Vector } \\
\text { Borne Infectious } \\
\text { Diseases, National } \\
\text { Center for } \\
\text { Zoonotic, Vector } \\
\text { Borne, and Enteric } \\
\text { Diseases, Ft. } \\
\text { Collins, Co. }\end{array}$ & $\begin{array}{l}\text { dyn2@cdc.gov; } \\
\text { rebecca.eisen@cdc. } \\
\text { hhs.gov }\end{array}$ & (970) 266-3523 & $\begin{array}{l}3150 \text { Rampart Rd } \\
\text { Fort Collins CO } \\
80521\end{array}$ & Research biologist & \\
\hline Elderd, Bret D. & LSU & $\begin{array}{l}\text { Department of } \\
\text { Biological Sciences }\end{array}$ & elderd@1su.edu & $225-578-6733$ & $\begin{array}{l}206 \text { Life sciences } \\
\text { Annex } \\
\text { Baton Rouge, LA } \\
70803\end{array}$ & Assistant professor & \\
\hline Engeljohn, Dan & $\begin{array}{l}\text { Department of } \\
\text { Agriculture }\end{array}$ & $\begin{array}{l}\text { Office of Field } \\
\text { Operations }\end{array}$ & $\begin{array}{l}\text { daniel.engeljohn@f } \\
\text { sis.usda.gov }\end{array}$ & $\begin{array}{l}202-720-5439 \\
202-205-0495\end{array}$ & $\begin{array}{l}\text { Jamie Whitten } \\
\text { Building } \\
1400 \text { Independence } \\
\text { Avenue, SW } \\
\text { Room 344-E } \\
\text { Washington, DC } \\
\text { 20250-3700 }\end{array}$ & $\begin{array}{l}\text { Assistant } \\
\text { Administrator }\end{array}$ & \\
\hline
\end{tabular}


Biosurveillance Modelers and Stakeholders

\begin{tabular}{|c|c|c|c|c|c|c|c|}
\hline Name & Agency & Division & Email & Phone & Address & Position & Website(s) \\
\hline Epstein, Joshua & $\begin{array}{l}\text { Johns Hopkins } \\
\text { University }\end{array}$ & $\begin{array}{l}\text { Dept of Emergency } \\
\text { Medicine, Depts of } \\
\text { Economics, } \\
\text { Biostatistics, and } \\
\text { Environmental } \\
\text { Health }\end{array}$ & jepste15@jhmi.edu & & $\begin{array}{l}\text { Johns Hopkins } \\
\text { University School } \\
\text { of Medicine } 733 \mathrm{~N} \text {. } \\
\text { Broadway } \\
\text { Baltimore, MD } \\
21205\end{array}$ & $\begin{array}{l}\text { Professor of } \\
\text { Emergency } \\
\text { Medicine, Director } \\
\text { of the Center for } \\
\text { Advanced } \\
\text { Modeling in the } \\
\text { Social, Behavioral } \\
\text { and Health } \\
\text { Sciences }\end{array}$ & \\
\hline Eubank, Stephen & $\begin{array}{l}\text { Los Alamos/ } \\
\text { Virginia } \\
\text { Bioinformatics } \\
\text { Institute at Virginia } \\
\text { Tech }\end{array}$ & Physics & $\begin{array}{l}\text { seubank@vbi.vt.ed } \\
\text { u }\end{array}$ & (540) 231-2504 & $\begin{array}{l}\text { Virginia } \\
\text { Bioinformatics } \\
\text { Institute } \\
\text { Washington St. } \\
\text { MC } 0477 \\
\text { Blackburg VA } \\
24061\end{array}$ & $\begin{array}{l}\text { Adjunct Professor, } \\
\text { Deputy Director of } \\
\text { Network Dynamics } \\
\text { and Simulation } \\
\text { Science Laboratory }\end{array}$ & \\
\hline Fang, Haiping & $\begin{array}{l}\text { Chinese Academy } \\
\text { of Sciences, } \\
\text { Shanghai }\end{array}$ & $\begin{array}{l}\text { Shanghai Institute } \\
\text { of Applied Physics }\end{array}$ & $\begin{array}{l}\text { fanghaiping@sinap } \\
\text {.ac.cn }\end{array}$ & 86-21-39194785 & $\begin{array}{l}\text { Shanghai Institute } \\
\text { of Applied Physics } \\
\text { Chinese Academy } \\
\text { of Sciences P.O. } \\
\text { Box 800-204 } \\
\text { Shanghai 201800, } \\
\text { China }\end{array}$ & $\begin{array}{l}\text { Professor in } \\
\text { Physics }\end{array}$ & \\
\hline Ferguson, Neil M & $\begin{array}{l}\text { Imperial College } \\
\text { London }\end{array}$ & $\begin{array}{l}\text { Medical Research } \\
\text { Council Centre for } \\
\text { Outbreak Analysis } \\
\text { and Modeling, } \\
\text { School of Public } \\
\text { Health }\end{array}$ & $\begin{array}{l}\text { neil.ferguson@imp } \\
\text { erial.ac.uk }\end{array}$ & $\begin{array}{l}44(0) 207594 \\
3296\end{array}$ & $\begin{array}{l}\text { Medical School, St. } \\
\text { Mary's Campus }\end{array}$ & $\begin{array}{l}\text { Director, Centre for } \\
\text { Outbreak Analysis } \\
\text { and Modeling, } \\
\text { Professor }\end{array}$ & \\
\hline Focks, Dana & $\begin{array}{l}\text { University of } \\
\text { Florida }\end{array}$ & $\begin{array}{l}\text { Emerging } \\
\text { Pathogens Institute }\end{array}$ & $\underline{\text { dafocks@epi.ufl.ed }}$ & $352-294-5148$ & $\begin{array}{l}\text { Emerging } \\
\text { Pathogens Institute } \\
\text { University of } \\
\text { Florida } \\
\text { Gainesville, FL }\end{array}$ & Professor & \\
\hline
\end{tabular}


Biosurveillance Modelers and Stakeholders

\begin{tabular}{|c|c|c|c|c|c|c|c|}
\hline Name & Agency & Division & Email & Phone & Address & Position & Website(s) \\
\hline Gaver, Donald P. & Tulane University & $\begin{array}{l}\text { Department of } \\
\text { Biomedical } \\
\text { Engineering }\end{array}$ & dpg@tulane.edu & (504) 865-5150 & $\begin{array}{l}534 \text { Lindy Boggs } \\
\text { Building } \\
\text { Department of } \\
\text { Biomedical } \\
\text { Engineering } \\
\text { Tulane University } \\
\text { New Orleans, LA } \\
70118\end{array}$ & $\begin{array}{l}\text { Department Chair } \\
\text { of Biomedical } \\
\text { Engineering }\end{array}$ & $\begin{array}{l}\text { http://www.tulane.e } \\
\text { du/ dpg/vitaeDPG. } \\
\text { html }\end{array}$ \\
\hline George, Dylan & HHS & $\begin{array}{l}\text { Office of } \\
\text { Preparedness and } \\
\text { Response }\end{array}$ & $\begin{array}{l}\text { dylan.george@hhs. } \\
\text { gov }\end{array}$ & & & & \\
\hline Germann, Tim & LANL & $\begin{array}{l}\text { Theoretical } \\
\text { Division, Physics } \\
\text { and Chemistry of } \\
\text { Materials Group }\end{array}$ & tcg@lanl.gov & $505-665-9772$ & & $\begin{array}{l}\text { Modeling and Sim } \\
\text { Scientist }\end{array}$ & \\
\hline Ghosh, Debarchana & $\begin{array}{l}\text { University of } \\
\text { Connecticut }\end{array}$ & $\begin{array}{l}\text { Department of } \\
\text { Geography }\end{array}$ & $\begin{array}{l}\text { debarchana.ghosh } \\
\text { @uconn.edu }\end{array}$ & (860) 486-4292 & $\begin{array}{l}\text { Department of } \\
\text { Geography } \\
\text { University of } \\
\text { Connecticut } \\
215 \text { Glenbrook } \\
\text { Road Rm } 422 \text { U- } \\
4148 \\
\text { Storrs, CT } 06269\end{array}$ & Assistant Professor & \\
\hline Ghosh, Mini & $\begin{array}{l}\text { Indian Institute of } \\
\text { Technology, } \\
\text { Kanpur, India/ } \\
\text { School of } \\
\text { Mathematics and } \\
\text { Computer } \\
\text { Application Thapar } \\
\text { University }\end{array}$ & $\begin{array}{l}\text { Department of } \\
\text { Mathematics }\end{array}$ & $\begin{array}{l}\text { mini_ghosh@yaho } \\
\text { o.co.in }\end{array}$ & $0091-9876254133$ & $\begin{array}{l}\text { School of } \\
\text { Mathematics and } \\
\text { Computer } \\
\text { Application, } \\
\text { Thapar University, } \\
\text { Patiala - 147004, } \\
\text { India }\end{array}$ & Assistant Professor & \\
\hline Granger, Larry & USDA & $\begin{array}{l}\text { Center for } \\
\text { Epidemiology and } \\
\text { Animal Health }\end{array}$ & $\begin{array}{l}\text { larry.m.granger@a } \\
\text { phis.usda.gov }\end{array}$ & $970-494-7200$ & $\begin{array}{l}2150 \text { Center Ave, } \\
\text { Building B, Mail } \\
\text { Stop 2E3 } \\
\text { Fort Collins, CO } \\
80526-8117\end{array}$ & Executive Director & \\
\hline
\end{tabular}


Biosurveillance Modelers and Stakeholders

\begin{tabular}{|c|c|c|c|c|c|c|c|}
\hline Name & Agency & Division & Email & Phone & Address & Position & Website(s) \\
\hline $\begin{array}{l}\text { Grassly, Nicholas } \\
\text { C }\end{array}$ & Imperial College & $\begin{array}{l}\text { School of Public } \\
\text { Health }\end{array}$ & $\begin{array}{l}\text { n.grassly@imperial } \\
\underline{\text { ac.uk }}\end{array}$ & & $\begin{array}{l}\text { School of Public } \\
\text { Health, G36, } \\
\text { Medical School, St. } \\
\text { Mary's Campus }\end{array}$ & Professor & \\
\hline Griffith, Brian & $\begin{array}{l}\text { Vanderbilt } \\
\text { Peabody College }\end{array}$ & $\begin{array}{l}\text { Human and } \\
\text { Organizational } \\
\text { Development }\end{array}$ & $\begin{array}{l}\text { brian.griffith@hhs. } \\
\text { gov and } \\
\text { brian.griffith@van } \\
\text { derbilt.edu }\end{array}$ & $615-322-8486$ & $\begin{array}{l}\text { Peabody \#90 } 230 \\
\text { Appleton Place } \\
\text { Nashville TN } \\
37203\end{array}$ & $\begin{array}{l}\text { Assistant Clinical } \\
\text { Professor, Director }\end{array}$ & \\
\hline Hartley, David & Georgetown & ARGUS & $\begin{array}{l}\text { dh268@georgetow } \\
\text { n.edu; } \\
\text { hartley@isis.georg } \\
\text { etown.edu }\end{array}$ & 202-687-9337 & $\begin{array}{l}6032115 \\
\text { Wisconsin Ave } \\
\text { NW }\end{array}$ & $\begin{array}{l}\text { Director, Associate } \\
\text { professor }\end{array}$ & \\
\hline Hartnett, Emma & $\begin{array}{l}\text { Risk Sciences } \\
\text { International, } \\
\text { Ottawa }\end{array}$ & $\begin{array}{l}\text { Risk Assessment of } \\
\text { Biological Systems }\end{array}$ & $\begin{array}{l}\text { ehartnett@ riskscie } \\
\text { ncesint.com; } \\
\text { ehartnett@analyzer } \\
\text { isk.com }\end{array}$ & $\begin{array}{l}(613) 260-1424 \text { ext } \\
152\end{array}$ & $\begin{array}{l}\text { Risk Sciences } \\
\text { International Inc } \\
\text { Suite 200-449 } \\
\text { Sussex Dr Ottawa } \\
\text { Ontario K1N6ZA } \\
\text { Canada }\end{array}$ & $\begin{array}{l}\text { Director, Modeling } \\
\text { and Simulation } \\
\text { Specialist }\end{array}$ & \\
\hline Hay, Simon & $\begin{array}{l}\text { University of } \\
\text { Oxford }\end{array}$ & $\begin{array}{l}\text { Spatial Ecology } \\
\text { and Epidemiology } \\
\text { Group }\end{array}$ & $\begin{array}{l}\text { simon.hay@zoo.ox } \\
\text {.ac.uk }\end{array}$ & $44(0) 1865271243$ & $\begin{array}{l}\text { The Tinbergen } \\
\text { Building } \\
\text { South Parks Road } \\
\text { Oxford, OX1 3PS } \\
\text { UK }\end{array}$ & Professor & $\begin{array}{l}\text { http://simonhay.zo } \\
\text { o.oz.ac.uk/index.ph } \\
\text { p }\end{array}$ \\
\hline Hickman, Martin & $\begin{array}{l}\text { Department of } \\
\text { Agriculture }\end{array}$ & $\begin{array}{l}\text { Food Safety and } \\
\text { Inspection }\end{array}$ & $\begin{array}{l}\text { martin.hickman@fs } \\
\text { is.usda.gov }\end{array}$ & & Des Moines, IA & $\begin{array}{l}\text { Senior operations } \\
\text { officer }\end{array}$ & \\
\hline $\begin{array}{l}\text { Hollingsworth, } \mathrm{T} \text {. } \\
\text { Deirdre }\end{array}$ & $\begin{array}{l}\text { Imperial College } \\
\text { London }\end{array}$ & $\begin{array}{l}\text { Medical Research } \\
\text { Council Centre for } \\
\text { Outbreak Analysis } \\
\text { and Modeling, } \\
\text { School of Public } \\
\text { Health }\end{array}$ & $\begin{array}{l}\text { d.hollingsworth@i } \\
\text { mperial.ac.uk }\end{array}$ & $\begin{array}{l}44(0) 207594 \\
3007\end{array}$ & $\begin{array}{l}\text { G22, Norfolk } \\
\text { Place, St. Mary's } \\
\text { Campus }\end{array}$ & $\begin{array}{l}\text { Junior Research } \\
\text { Fellow }\end{array}$ & $\begin{array}{l}\text { http://www1.imperi } \\
\text { al.ac.uk/medicine/p } \\
\text { eople/d.hollingswo } \\
\text { rth/ }\end{array}$ \\
\hline Hsu, Sze-Bi & $\begin{array}{l}\text { National Tsing Hua } \\
\text { University }\end{array}$ & $\begin{array}{l}\text { Department of } \\
\text { Mathematics }\end{array}$ & $\begin{array}{l}\text { sbhsu@math.nthu.e } \\
\text { du.tw }\end{array}$ & & $\begin{array}{l}\text { Department of } \\
\text { Mathematics, } \\
\text { National Tsing- } \\
\text { Hua University, } \\
\text { Hsinchu, Taiwan } \\
300\end{array}$ & Professor & $\begin{array}{l}\text { http://www.math.nt } \\
\text { hu.edu.tw/ sbhsu/ }\end{array}$ \\
\hline
\end{tabular}


Biosurveillance Modelers and Stakeholders

\begin{tabular}{|c|c|c|c|c|c|c|c|}
\hline Name & Agency & Division & Email & Phone & Address & Position & Website(s) \\
\hline Huff, Bill & DOD/DTRA & $\begin{array}{l}\text { Chemical and } \\
\text { Biological } \\
\text { operations division }\end{array}$ & $\begin{array}{l}\text { william.huff@dtra. } \\
\text { mil }\end{array}$ & $703-767-6301$ & & $\mathrm{COO}$ & \\
\hline Hullinger, Pam & UC Davis & $\begin{array}{l}\text { Department of } \\
\text { Medicine and } \\
\text { Epidemiology, } \\
\text { School of } \\
\text { Veterinary } \\
\text { Medicine }\end{array}$ & $\begin{array}{l}\text { phullinger@ucdavi } \\
\text { s.edu }\end{array}$ & $\begin{array}{l}925-321-3248 \text { or } \\
530-754-8693\end{array}$ & 2103 Tupper Hall & $\begin{array}{l}\text { Associate Clinical } \\
\text { Professor }\end{array}$ & \\
\hline Hupert, Nathaniel & Cornell, DHHS & $\begin{array}{l}\text { Associate Professor } \\
\text { of Public Health } \\
\text { and Medicine at } \\
\text { Weill Medical } \\
\text { College, Anthrax } \\
\text { Modeling Working } \\
\text { Group }\end{array}$ & $\begin{array}{l}\text { nah2005@med.cor } \\
\text { nell.edu }\end{array}$ & $212-746-3587$ & $\begin{array}{l}505 \text { East 70th } \\
\text { Street } \\
\text { New York, NY } \\
10021\end{array}$ & $\begin{array}{l}\text { Associate Professor } \\
\text { of Medicine }\end{array}$ & $\begin{array}{l}\text { www.med.cornell.e } \\
\text { du/research/nathani } \\
\text { elhupert/biography. } \\
\text { html }\end{array}$ \\
\hline Jackson, LeeAnne & HHS/FDA & $\begin{array}{l}\text { Center for Food } \\
\text { Safety and Applied } \\
\text { Nutrition, Office of } \\
\text { Food Defense, } \\
\text { Communication, } \\
\text { and Emergency } \\
\text { Response }\end{array}$ & $\begin{array}{l}\text { leeanne.jackson@f } \\
\text { da.hhs.gov }\end{array}$ & $\begin{array}{l}301-436-1593 \\
240-402-1593\end{array}$ & $\begin{array}{l}\text { College Park, MD } \\
20740\end{array}$ & $\begin{array}{l}\text { Health Science } \\
\text { Policy advisor, co- } \\
\text { chair of the Food } \\
\text { and Agriculture } \\
\text { Sector Govt. } \\
\text { Coordin. Council }\end{array}$ & \\
\hline Jackson, Paul & $\begin{array}{l}\text { Lawrence } \\
\text { Livermore National } \\
\text { Laboratory }\end{array}$ & $\begin{array}{l}\text { Global Security } \\
\text { and Physical and } \\
\text { Life Sciences } \\
\text { Directorate }\end{array}$ & $\begin{array}{l}\text { jackson80@1lnl.go } \\
\text { v }\end{array}$ & $925-424-2725$ & $\begin{array}{l}7000 \text { East Ave., L- } \\
172 \\
\text { Lawrence } \\
\text { Livermore National } \\
\text { Laboratory } \\
\text { Livermore, CA } \\
94551\end{array}$ & Senior Scientist & \\
\hline Jacob, Benjamin G. & UAB & $\begin{array}{l}\text { Division of } \\
\text { Infectious } \\
\text { Diseases, } \\
\text { Department of } \\
\text { Medicine, } \\
\text { Department of } \\
\text { Epidemiology }\end{array}$ & bjacob@uab.edu & 205-996-7894 & & Research Assistant & \\
\hline
\end{tabular}


Biosurveillance Modelers and Stakeholders

\begin{tabular}{|c|c|c|c|c|c|c|c|}
\hline Name & Agency & Division & Email & Phone & Address & Position & Website(s) \\
\hline Jamison, Jamie & FBI & & $\begin{array}{l}\text { selwyn.jamison@ic } \\
\text {.fbi.gov }\end{array}$ & $202-324-0279$ & & $\begin{array}{l}\text { NIWG Principal, } \\
\text { Manager of the } \\
\text { Bioterrorism } \\
\text { Prevention } \\
\text { Program }\end{array}$ & \\
\hline Jewell, C.P. (Chris) & $\begin{array}{l}\text { University of New } \\
\text { Zealand, Massey } \\
\text { University }\end{array}$ & $\begin{array}{l}\text { Statistics and } \\
\text { Bioinformatics } \\
\text { group }\end{array}$ & $\begin{array}{l}\text { C.P.Jewell@masse } \\
\text { y.ac.nz }\end{array}$ & $\begin{array}{l}6463569099 \text { ext } \\
3586\end{array}$ & $\begin{array}{l}\text { ScB3.27, Science } \\
\text { Tower B, } \\
\text { Manawatu Campus }\end{array}$ & $\begin{array}{l}\text { Lecturer in } \\
\text { Biostatistics }\end{array}$ & \\
\hline Johansson, Anders & $\begin{array}{l}\text { Swedish Defense } \\
\text { Research Agency, } \\
\text { Umea University }\end{array}$ & $\begin{array}{l}\text { Department of } \\
\text { Clinical } \\
\text { Microbiology, } \\
\text { Bacteriology and } \\
\text { Infectious Diseases }\end{array}$ & $\begin{array}{l}\text { anders.johansson@ } \\
\text { climi.umu.se; } \\
\text { anders.johansson@ } \\
\text { infdis.umu.se }\end{array}$ & 46907851732 & $\begin{array}{l}\text { Department of } \\
\text { Hospital Infection } \\
\text { Control } \\
\text { SE-901 } 85 \text { Umea } \\
\text { Sweden }\end{array}$ & Senior lecturer & \\
\hline Johnson, Leah & $\begin{array}{l}\text { University of } \\
\text { Chicago }\end{array}$ & $\begin{array}{l}\text { Department of } \\
\text { Ecology and } \\
\text { Evolution }\end{array}$ & $\begin{array}{l}\text { lrjohnson@uchicag } \\
\text { o.edu }\end{array}$ & & $\begin{array}{l}1101 \text { E. 57th Street } \\
\text { Chicago, IL } 60637\end{array}$ & $\begin{array}{l}\text { Research } \\
\text { professional }\end{array}$ & $\begin{array}{l}\text { http://leah.johnson- } \\
\text { gramacy.com/ }\end{array}$ \\
\hline Johnson, Robert & DOD/STRATCOM & SCC-WMD & $\begin{array}{l}\text { Robert.Johnson@dt } \\
\text { ra.mil }\end{array}$ & & & & \\
\hline Kaplan, Edward H. & Yale & $\begin{array}{l}\text { School of } \\
\text { Engineering and } \\
\text { Applied Science, } \\
\text { Department of } \\
\text { Chemical } \\
\text { Engineering }\end{array}$ & $\begin{array}{l}\text { edward.kaplan@ya } \\
\text { le.edu }\end{array}$ & (203) 432-6031 & $\begin{array}{l}\text { Yale School of } \\
\text { Management } \\
\text { PO Box 20820 } \\
\text { New Haven, CT } \\
06520-8200\end{array}$ & Professor & $\begin{array}{l}\text { http://faculty.som.y } \\
\text { ale.edu/EdKaplan/ }\end{array}$ \\
\hline $\begin{array}{l}\text { Kaufmann, } \\
\text { Arnold.F. }\end{array}$ & $\mathrm{CDC}$ & $\begin{array}{l}\text { Environmental } \\
\text { Public Health } \\
\text { Readiness }\end{array}$ & & & & Retired & \\
\hline Keim, Paul & $\begin{array}{l}\text { Northern Arizona } \\
\text { University }\end{array}$ & $\begin{array}{l}\text { Pathogen } \\
\text { Genomics } \\
\text { Division, Biology, } \\
\text { The Translational } \\
\text { Genomics } \\
\text { Research Institute }\end{array}$ & pkeim@tgen.org & $928-523-1078$ & & $\begin{array}{l}\text { Professor of } \\
\text { Biology, Director }\end{array}$ & \\
\hline Kim, Deok Ryun & $\begin{array}{l}\text { International } \\
\text { Vaccine Institute, }\end{array}$ & $\begin{array}{l}\text { Translational } \\
\text { Research Division }\end{array}$ & drkim@ivi.int & & $\begin{array}{l}\text { South Korea } \\
\text { Institute of } \\
\text { Hygiene and } \\
\text { Epidemiology, } \\
\text { Vietnam }\end{array}$ & $\begin{array}{l}\text { Senior Statistical } \\
\text { Analyst }\end{array}$ & \\
\hline
\end{tabular}


Biosurveillance Modelers and Stakeholders

\begin{tabular}{|c|c|c|c|c|c|c|c|}
\hline Name & Agency & Division & Email & Phone & Address & Position & Website(s) \\
\hline Kim-hung, Kwong & $\begin{array}{l}\text { University of Hong } \\
\text { Kong }\end{array}$ & $\begin{array}{l}\text { Department of } \\
\text { Geography }\end{array}$ & $\begin{array}{l}\text { h0110454@hkusua } \\
\text {.hku.hk }\end{array}$ & $852-2859-7028$ & & Graduated & \\
\hline Kircher, Amy & $\begin{array}{l}\text { University of } \\
\text { Minnesota }\end{array}$ & $\begin{array}{l}\text { National Center for } \\
\text { Food Protection } \\
\text { and Defense }\end{array}$ & & $612-624-2458$ & $\begin{array}{l}\text { University of } \\
\text { Minnesota - Twin } \\
\text { Cities Campus } \\
\text { 120 LES Building } \\
\text { 1954 Buford Ave } \\
\text { St Paul MN } 55108\end{array}$ & $\begin{array}{l}\text { Epidemiologist, } \\
\text { Associate Director }\end{array}$ & \\
\hline Knott, Debbie & $\begin{array}{l}\text { Department of } \\
\text { Agriculture }\end{array}$ & APHIS PPQ & $\begin{array}{l}\text { deborah.m.knott@a } \\
\text { phis.usda.gov; } \\
\text { Deborah.knott@os } \\
\text { ec.gov }\end{array}$ & & $\begin{array}{l}4700 \text { River Road, } \\
\text { 4th floor } \\
\text { Riverdale, MD } \\
20737\end{array}$ & & \\
\hline Lee, Bruce Y. & $\begin{array}{l}\text { University of } \\
\text { Pittsburgh }\end{array}$ & $\begin{array}{l}\text { Division of General } \\
\text { Internal Medicine }\end{array}$ & BYL1@ @itt.edu & $412-246-6934$ & $\begin{array}{l}\text { University of } \\
\text { Pittsburgh } \\
200 \text { Meyran Ave, } \\
\text { Suite } 200 \\
\text { Pittsburgh, PA } \\
15213\end{array}$ & $\begin{array}{l}\text { Associate } \\
\text { Professor, Director } \\
\text { of Public Health } \\
\text { Computational and } \\
\text { Operations } \\
\text { Research Group }\end{array}$ & \\
\hline Lee, Eva & Georgia Tech & $\begin{array}{l}\text { Center for } \\
\text { Operations } \\
\text { Research in } \\
\text { Medicine and } \\
\text { Healthcare }\end{array}$ & $\begin{array}{l}\text { eva.lee@gatech.ed } \\
\text { u }\end{array}$ & (404) 894-4962 & $\begin{array}{l}\text { Georgia Institute of } \\
\text { Technology } \\
\text { Atlanta, GA } \\
30332-0205\end{array}$ & Director, Professor & \\
\hline Liao, Chung-Min & $\begin{array}{l}\text { National Taiwan } \\
\text { University }\end{array}$ & $\begin{array}{l}\text { Department of } \\
\text { Bioenvironmental } \\
\text { Systems } \\
\text { Engineering }\end{array}$ & cmliao@ntu.edu.tw & $886-2-2363-4512$ & $\begin{array}{l}\text { National Taiwan } \\
\text { University } \\
\text { Taipei, Taiwan } \\
10617 \\
\text { ROC }\end{array}$ & & \\
\hline Linthicum, Ken & USDA & $\begin{array}{l}\text { Center for Medical, } \\
\text { Agricultural \& } \\
\text { Veterinary } \\
\text { Entomology }\end{array}$ & $\begin{array}{l}\text { kenneth.linthicum } \\
\text { @ars.usda.gov }\end{array}$ & $352-374-5901$ & & Center Director & $\begin{array}{l}\underline{\text { http://www.ars.usd }} \\
\underline{\text { a.gov/saa/cmave/kj }} \\
\underline{\text { linthicum }}\end{array}$ \\
\hline Lipsitch, Marc & Harvard University & $\begin{array}{l}\text { Department of } \\
\text { Epidemiology and } \\
\text { Immunology and } \\
\text { Infectious } \\
\text { Diseases, Center } \\
\text { for Communicable } \\
\text { Disease Dynamics }\end{array}$ & $\begin{array}{l}\text { mlipsitc@hsph.har } \\
\text { vard.edu }\end{array}$ & 617.432 .4559 & $\begin{array}{l}677 \text { Huntington } \\
\text { Avenue } \\
\text { Kresge Building, } \\
\text { Office 506G } \\
\text { Boston, } \\
\text { Massachusetts } \\
02115\end{array}$ & $\begin{array}{l}\text { Professor of } \\
\text { Epidemiology, } \\
\text { Director CCDD }\end{array}$ & $\begin{array}{l}\text { http://www.hsph.ha } \\
\text { rvard.edu/faculty/m } \\
\text { arc-lipsitch/ }\end{array}$ \\
\hline
\end{tabular}


Biosurveillance Modelers and Stakeholders

\begin{tabular}{|c|c|c|c|c|c|c|c|}
\hline Name & Agency & Division & Email & Phone & Address & Position & Website(s) \\
\hline Lloyd-Smith, Jamie & UCLA, NIH & $\begin{array}{l}\text { Ecology and } \\
\text { Evolutionary } \\
\text { Biology, RAPIDD, } \\
\text { Fogarty } \\
\text { International } \\
\text { Center }\end{array}$ & $\begin{array}{l}\text { jlloydsmith@ucla.e } \\
\text { du }\end{array}$ & $310-206-8207$ & $\begin{array}{l}610 \text { Charles E. } \\
\text { Young Dr. South } \\
\text { Box } 723905 \\
\text { Los Angeles, CA } \\
90095-7239\end{array}$ & $\begin{array}{l}\text { De Logi Chair in } \\
\text { Biological } \\
\text { Sciences, } \\
\text { Professor, Research } \\
\text { Associate at NIH }\end{array}$ & $\begin{array}{l}\text { https://www.eeb.uc } \\
\text { la.edu/Faculty/lloy } \\
\text { dsmith/index.php }\end{array}$ \\
\hline Longini, Ira & $\begin{array}{l}\text { University of } \\
\text { Florida }\end{array}$ & $\begin{array}{l}\text { College of Public } \\
\text { Health }\end{array}$ & ilongini@ufl.edu & $404-275-5156$ & $\begin{array}{l}\text { Emerging } \\
\text { Pathogens Institute } \\
\text { University of } \\
\text { Florida } \\
\text { Gainesville, FL }\end{array}$ & Professor & $\begin{array}{l}\text { http://csquid.org/pe } \\
\text { ople/ira-m-longini- } \\
\text { jr-phd/ }\end{array}$ \\
\hline Lynn, Tracey & USDA & $\begin{array}{l}\text { Center for Animal } \\
\text { Health Information } \\
\text { and Analysis, } \\
\text { National Center for } \\
\text { Risk Analysis }\end{array}$ & $\begin{array}{l}\text { tracey.v.lynn@aphi } \\
\text { s.usda.gov }\end{array}$ & $970-494-7597$ & Fort Collins, CO & Director & \\
\hline Mayer, Dieter & TU Clausthal & $\begin{array}{l}\text { Institute of } \\
\text { Theoretical Physics }\end{array}$ & $\begin{array}{l}\text { dieter.mayer@tu- } \\
\text { clausthal.de; } \\
\text { dieter.mayer@usz. } \\
\text { ch }\end{array}$ & $49-5323-72-3004$ & & Professor & \\
\hline $\begin{array}{l}\text { Meyers, Lauren } \\
\text { Ancel }\end{array}$ & $\begin{array}{l}\text { University of } \\
\text { Texas, Austin }\end{array}$ & $\begin{array}{l}\text { Division of } \\
\text { Statistics and } \\
\text { Scientific } \\
\text { Computation }\end{array}$ & $\begin{array}{l}\text { laurenmeyers@mai } \\
\text { l.utexas.edu }\end{array}$ & $512-471-4950$ & $\begin{array}{l}\text { Section of } \\
\text { Integrative Biology } \\
\text { University of Texas } \\
\text { at Austin } \\
1 \text { University } \\
\text { Station C0930 } \\
\text { Austin, Texas } \\
78712\end{array}$ & Director, Professor & $\begin{array}{l}\text { http://www.bio.ute } \\
\text { xas.edu/research/m } \\
\text { eyers/index.html }\end{array}$ \\
\hline Mollison, Denis & $\begin{array}{l}\text { Heriot-Watt } \\
\text { University }\end{array}$ & $\begin{array}{l}\text { Department of } \\
\text { Actuarial } \\
\text { Mathematics and } \\
\text { Statistics }\end{array}$ & $\begin{array}{l}\text { denis@ma.hw.ac.u } \\
\text { k }\end{array}$ & $44-131-665-2055$ & & $\begin{array}{l}\text { Professor of } \\
\text { Applied Probability } \\
\text { (Emeritus) }\end{array}$ & \\
\hline Moore, Chris & $\begin{array}{l}\text { Department of } \\
\text { Commerce }\end{array}$ & $\begin{array}{l}\text { Mid-Atlantic } \\
\text { Fishery } \\
\text { Management } \\
\text { Council }\end{array}$ & $\begin{array}{l}\text { christopher.s.moore } \\
\text { @ noaa.gov }\end{array}$ & $877-446-2362$ & $\begin{array}{l}800 \text { North State } \\
\text { Street, Suite } 201 \\
\text { Dover, DE } 19901\end{array}$ & Executive Director & \\
\hline
\end{tabular}


Biosurveillance Modelers and Stakeholders

\begin{tabular}{|c|c|c|c|c|c|c|c|}
\hline Name & Agency & Division & Email & Phone & Address & Position & Website(s) \\
\hline Mores, Christopher & $\begin{array}{l}\text { Louisiana State } \\
\text { University }\end{array}$ & $\begin{array}{l}\text { Epidemiology, } \\
\text { Centre of } \\
\text { Biomedical } \\
\text { Research } \\
\text { Excellence }\end{array}$ & cmores@1su.edu & $225-578-9676$ & & Associate Professor & \\
\hline Morici, Kathryn & DOD/NCMI & $\begin{array}{l}\text { Infectious Disease } \\
\text { Division }\end{array}$ & $\begin{array}{l}\text { kmorici@ncmi.detr } \\
\text { ick.army.mil }\end{array}$ & & & Chief & \\
\hline Mubangizi, Martin & $\begin{array}{l}\text { Makerere } \\
\text { University, Uganda }\end{array}$ & $\begin{array}{l}\text { School of } \\
\text { Computing and } \\
\text { Informatics } \\
\text { Technology }\end{array}$ & $\begin{array}{l}\text { mmubangizi@cit.m } \\
\text { ak.ac.ug }\end{array}$ & & & $\begin{array}{l}\text { Assistant Lecturer } \\
\text { and Information } \\
\text { Systems Doctoral } \\
\text { Student }\end{array}$ & \\
\hline Nelson, Noele & Georgetown & $\begin{array}{l}\text { ARGUS, } \\
\text { Department of } \\
\text { Pediatrics }\end{array}$ & $\begin{array}{l}\text { nelson@isis.george } \\
\text { town.edu; } \\
\text { npn@georgetown.e } \\
\text { du }\end{array}$ & $\begin{array}{l}202-577-4475 \\
202-379-8259\end{array}$ & $\begin{array}{l}\text { MedStar } \\
\text { Georgetown } \\
\text { University Hospital } \\
3800 \text { Reservoir Rd, } \\
\text { NW } \\
\text { Pasquerilla } \\
\text { Healthcare Center } \\
\text { Washington, DC } \\
20007\end{array}$ & $\begin{array}{l}\text { Deputy Director, } \\
\text { Assistant Professor }\end{array}$ & \\
\hline Nordin, James D. & $\begin{array}{l}\text { Health Partners } \\
\text { Research } \\
\text { Foundation }\end{array}$ & $\begin{array}{l}\text { Medical and Dental } \\
\text { Group }\end{array}$ & $\begin{array}{l}\text { James.D.Nordin@ } \\
\text { HealthPartners.com }\end{array}$ & $952-967-5087$ & $\begin{array}{l}\text { HealthPartners St. } \\
\text { Paul Clinic } \\
205 \text { S Wabasha St } \\
\text { St. Paul, MN }\end{array}$ & $\begin{array}{l}\text { Pediatrician, chair } \\
\text { of the } \\
\text { Immunization } \\
\text { Expert Panel and } \\
\text { medical advisor for } \\
\text { the Immunization } \\
\text { Registry }\end{array}$ & \\
\hline Nurthen, Nancy & DOD/DTRA & $\begin{array}{l}\text { Medical \& } \\
\text { Surveillance } \\
\text { Information } \\
\text { \&Analysis }\end{array}$ & $\begin{array}{l}\text { nancy.nurthen@dtr } \\
\text { a.mil }\end{array}$ & & & $\begin{array}{l}\text { Science \& } \\
\text { Technology } \\
\text { Manager }\end{array}$ & \\
\hline O'Connor, Ralph & HHS/CDC & & $\begin{array}{l}\text { ralph.oconnor@cdc } \\
\text {.hhs.gov; } \\
\text { ROConnor@cdc.go } \\
\text { v }\end{array}$ & $404-915-4765$ & $\begin{array}{l}\text { CLFT, Room DEO } \\
\text { Atlanta, GA } \\
30329-4018\end{array}$ & $\begin{array}{l}\text { Lead Public Health } \\
\text { Advisor }\end{array}$ & \\
\hline
\end{tabular}


Biosurveillance Modelers and Stakeholders

\begin{tabular}{|c|c|c|c|c|c|c|c|}
\hline Name & Agency & Division & Email & Phone & Address & Position & Website(s) \\
\hline Ohkusa, Yasushi & $\begin{array}{l}\text { National Institute } \\
\text { of Infectious } \\
\text { Diseases, Tokyo } \\
\text { Japan }\end{array}$ & $\begin{array}{l}\text { Infectious Disease } \\
\text { Surveillance Center }\end{array}$ & ohkusa@nih.go.jp & $81-3-5285-1111$ & $\begin{array}{l}\text { Infectious Disease } \\
\text { Surveillance Center } \\
\text { National Institute } \\
\text { of Infectious } \\
\text { Diseases } \\
\text { 1-23-1 Toyama, } \\
\text { Shinjuku-ku } \\
\text { Tokyo 162-8640, } \\
\text { Japan }\end{array}$ & Chief researcher & \\
\hline Olsen, Jennifer & HHS/ASPR & $\begin{array}{l}\text { Office of } \\
\text { Preparedness \& } \\
\text { Emergency } \\
\text { Operations }\end{array}$ & $\begin{array}{l}\text { Jennifer.Olsen@hh } \\
\text { s.gov }\end{array}$ & $202-205-4729$ & Washington, DC & Branch Chief & \\
\hline $\begin{array}{l}\text { O'Reilly, Kathleen } \\
\text { M. }\end{array}$ & $\begin{array}{l}\text { Imperial College } \\
\text { London }\end{array}$ & $\begin{array}{l}\text { Medical Research } \\
\text { Council Centre for } \\
\text { Outbreak Analysis } \\
\text { and Modeling, } \\
\text { School of Public } \\
\text { Health }\end{array}$ & $\begin{array}{l}\text { k.oreilly@imperial. } \\
\text { ac.uk }\end{array}$ & & & & \\
\hline $\begin{array}{l}\text { Ortega, Neli } \\
\text { Regina Siqueira }\end{array}$ & $\begin{array}{l}\text { University of Sao } \\
\text { Paulo }\end{array}$ & $\begin{array}{l}\text { Medical } \\
\text { Informatics, } \\
\text { Faculty of } \\
\text { Medicine }\end{array}$ & $\begin{array}{l}\text { neli@dim.fm.usp.b } \\
\mathrm{r}\end{array}$ & (11) 30617682 & $\begin{array}{l}\text { University of Sao } \\
\text { Paulo, Faculty of } \\
\text { Medicine, } \\
\text { University of } \\
\text { Birmingham, } \\
\text { Department of } \\
\text { Pathology } \\
\text { Rua Teodoro } \\
\text { Sampaio } 115 \text { - } \\
\text { Discipline of } \\
\text { Informatics - } \\
\text { LIM01 } \\
\text { Cerqueira Cesar } \\
\text { 05405-000 - Sao } \\
\text { Paulo, SP - Brazil }\end{array}$ & Tenured Professor & $\begin{array}{l}\text { http://lattes.cnpq.br } \\
/ 600175225658473 \\
5\end{array}$ \\
\hline Pascual, Mercedes & $\begin{array}{l}\text { University of } \\
\text { Michigan }\end{array}$ & $\begin{array}{l}\text { Dept of Ecology } \\
\text { and Evolutionary } \\
\text { Biology }\end{array}$ & $\begin{array}{l}\text { pascual@umich.ed } \\
\underline{\mathrm{u}}\end{array}$ & 734-615-9808 & $\begin{array}{l}\text { 2039/2041 Kraus } \\
\text { Natural Science } \\
\text { Bldg, } 830 \text { North } \\
\text { University, Ann } \\
\text { Arbor, MI 48109- }\end{array}$ & Professor & \\
\hline
\end{tabular}


Biosurveillance Modelers and Stakeholders

\begin{tabular}{|c|c|c|c|c|c|c|c|}
\hline Name & Agency & Division & Email & Phone & Address & Position & Website(s) \\
\hline & & & & & 1048 & & \\
\hline Perez, Andres & UC Davis & $\begin{array}{l}\text { Center for Animal } \\
\text { Disease Modeling } \\
\text { and Surveillance } \\
\text { (CADMS) }\end{array}$ & $\begin{array}{l}\text { amperez@ucdavis. } \\
\text { edu }\end{array}$ & $530-752-0336$ & $\begin{array}{l}\text { Department of } \\
\text { Medicine and } \\
\text { Epidemiology } \\
\text { Room } 1044 \text { Haring } \\
\text { hall } \\
\text { University of } \\
\text { California } \\
\text { Davis, CA } 95616\end{array}$ & $\begin{array}{l}\text { Coordinates } \\
\text { BioPortal } \\
\text { Activities, } \\
\text { Associate } \\
\text { Researcher, Acting } \\
\text { Director of } \\
\text { CADMS }\end{array}$ & \\
\hline Porco, Travis C. & $\begin{array}{l}\text { University of } \\
\text { California } \\
\text { Berkeley/ } \\
\text { University of } \\
\text { California SF }\end{array}$ & $\begin{array}{l}\text { Division of } \\
\text { Preventive } \\
\text { Medicine and } \\
\text { Public Health, Dept } \\
\text { of Epidemiology } \\
\text { and Biostatistics, } \\
\text { and Department of } \\
\text { Ophthalmology, } \\
\text { Francis I Proctor } \\
\text { Institute for } \\
\text { Research in } \\
\text { Ophthalmology }\end{array}$ & $\begin{array}{l}\text { travis.porco@ucsf. } \\
\text { edu; } \\
\text { tcporco@mathepi.c } \\
\text { om }\end{array}$ & $415-476-4101$ & $\begin{array}{l}\text { Travis C. Porco, } \\
\text { PhD, MPH } \\
\text { Box } 0412 \\
513 \text { Parnassus Ave } \\
\text { Room S351 } \\
\text { UCSF } \\
\text { San Francisco, CA, } \\
\text { 94143-0412 }\end{array}$ & $\begin{array}{l}\text { Adjunct associate } \\
\text { professor }\end{array}$ & $\begin{array}{l}\text { http://www.mathep } \\
\text { i.com/ }\end{array}$ \\
\hline $\begin{array}{l}\text { Postlewaite, R. } \\
\text { Craig }\end{array}$ & DoD & $\begin{array}{l}\text { Force Health } \\
\text { Protection and } \\
\text { Readiness } \\
\text { Programs; Force } \\
\text { Readiness and } \\
\text { Health Assurance }\end{array}$ & $\begin{array}{l}\text { Craig.Postlewaite } \\
@ \text { tma.osd.mil }\end{array}$ & $703-578-8513$ & & $\begin{array}{l}\text { Deputy Director } \\
\text { FHPRP, Director } \\
\text { FRHA }\end{array}$ & \\
\hline Pulz, Jessica & $\begin{array}{l}\text { Environmental } \\
\text { Protection Agency; } \\
\text { USDA }\end{array}$ & $\begin{array}{l}\text { Water Security; } \\
\text { Resiliency and } \\
\text { Preparedness } \\
\text { Division }\end{array}$ & $\begin{array}{l}\text { pulz.jessica@epa.g } \\
\text { ov; } \\
\text { Jessica.Pulz@osec. } \\
\text { usda.gov }\end{array}$ & $513-569-7918$ & $\begin{array}{l}26 \text { West Martin } \\
\text { Luther King Drive } \\
\text { Mail Code } 140 \\
\text { Cincinnati, OH } \\
45268\end{array}$ & Policy Analyst & \\
\hline
\end{tabular}


Biosurveillance Modelers and Stakeholders

\begin{tabular}{|c|c|c|c|c|c|c|c|}
\hline Name & Agency & Division & Email & Phone & Address & Position & Website(s) \\
\hline $\begin{array}{l}\text { Radosavljevic, } \\
\text { Vladan }\end{array}$ & $\begin{array}{l}\text { Military Academy, } \\
\text { Serbian Military } \\
\text { Medical Corps } \\
\text { Headquarters }\end{array}$ & $\begin{array}{l}\text { Biodefense, } \\
\text { Biosecurity, } \\
\text { Department of } \\
\text { Preventative } \\
\text { Medicine }\end{array}$ & $\begin{array}{l}\text { vladanr4@gmail.co } \\
\text { m }\end{array}$ & $49-40-42838-4383$ & Belgrade, Serbia & $\begin{array}{l}\text { Associate } \\
\text { Professor, Chief }\end{array}$ & \\
\hline Ray, Jaideep & $\begin{array}{l}\text { Sandia National } \\
\text { Laboratories }\end{array}$ & & jairay@sandia.gov & $925-294-3638$ & $\begin{array}{l}\text { Sandia National } \\
\text { Laboratories } \\
\text { MS 9159, PO Box } \\
969 \\
\text { Livermore, CA } \\
\text { 94551-0969 }\end{array}$ & $\begin{array}{l}\text { Principal Member } \\
\text { of Technical Staff, } \\
\text { Advanced Software } \\
\text { R. \& D. }\end{array}$ & $\begin{array}{l}\text { http://www.caip.rut } \\
\text { gers.edu/ jaray }\end{array}$ \\
\hline Ribeiro, Nathalie & $\begin{array}{l}\text { Centre National } \\
\text { d'Etudes Spatiales }\end{array}$ & & $\begin{array}{l}\text { nathalie.ribeiro@cn } \\
\text { es.fr }\end{array}$ & $\begin{array}{l}33(0) 1447677 \\
25\end{array}$ & & & \\
\hline Rohani, Pejman & $\begin{array}{l}\text { University of } \\
\text { Michigan }\end{array}$ & & rohani@umich.edu & $734-615-4757$ & & Professor & $\begin{array}{l}\text { http://www.cscs.lsa } \\
\text {.umich.edu/ rohani } \\
\text { / }\end{array}$ \\
\hline Roselle, Gary & $\begin{array}{l}\text { Department of } \\
\text { Veterans Affairs, } \\
\text { Cincinnati VA } \\
\text { Medical Center, } \\
\text { University of } \\
\text { Cincinnati College } \\
\text { of Medicine }\end{array}$ & Infectious Diseases & $\begin{array}{l}\text { gary.roselle@va.go } \\
\text { v }\end{array}$ & & $\begin{array}{l}\text { VHA Infectious } \\
\text { Diseases Program } \\
\text { Office Cincinnati } \\
\text { Veteran Affairs } \\
\text { Medical Center } \\
\text { Cincinnati, OH } \\
45220 \\
\text { USA }\end{array}$ & $\begin{array}{l}\text { Program Director, } \\
\text { Chief of Medicine, } \\
\text { Professor of } \\
\text { Medicine }\end{array}$ & \\
\hline Rubel, Franz & $\begin{array}{l}\text { University of } \\
\text { Veterinary } \\
\text { Medicine Vienna }\end{array}$ & $\begin{array}{l}\text { Biometeorology \& } \\
\text { Mathematical } \\
\text { Epidemiology } \\
\text { Group, Institute for } \\
\text { Veterinary Public } \\
\text { Health }\end{array}$ & $\begin{array}{l}\text { franz.rubel@vetme } \\
\text { duni.ac.at }\end{array}$ & $\begin{array}{l}+43(1) 25077- \\
3532\end{array}$ & $\begin{array}{l}\text { University of } \\
\text { Veterinary } \\
\text { Medicine Vienna } \\
\text { Veterinarplatz } 1 \\
\text { A-1210 Vienna, } \\
\text { Austria }\end{array}$ & Associate Professor & \\
\hline $\begin{array}{l}\text { Schlegelmilch, } \\
\text { Jeffrey }\end{array}$ & Yale & $\begin{array}{l}\text { Emergency } \\
\text { Management } \\
\text { Services, Yale New } \\
\text { Haven Center for } \\
\text { Emergency } \\
\text { Preparedness and } \\
\text { Disaster Response }\end{array}$ & $\begin{array}{l}\text { jeffrey.schlegelmil } \\
\text { ch@ynhh.org }\end{array}$ & $203-688-4485$ & $\begin{array}{l}\text { Yale New Haven } \\
\text { Center for } \\
\text { Emergency } \\
\text { Preparedness and } \\
\text { Disaster Response } \\
1 \text { Church Street, } \\
\text { 5th Floor } \\
\text { New Haven, CT } \\
06510\end{array}$ & Manager & \\
\hline
\end{tabular}


Biosurveillance Modelers and Stakeholders

\begin{tabular}{llllll}
\hline Name & Agency & Division & Email & Phone & Address \\
\hline
\end{tabular}

\begin{tabular}{|c|c|c|c|c|c|c|c|}
\hline Scott, Aaron & USDA & $\begin{array}{l}\text { National } \\
\text { Surveillance Unit }\end{array}$ & $\begin{array}{l}\text { aaron.e.scott@aphi } \\
\text { s.usda.gov }\end{array}$ & $970-494-7249$ & $\begin{array}{l}7103 \text { Ranger Dr } \\
\text { Fort Collins, CO } \\
80526\end{array}$ & Director & \\
\hline Shen, Yanna & $\begin{array}{l}\text { The Lister Hill } \\
\text { National Center for } \\
\text { Biomedical } \\
\text { Communications }\end{array}$ & & $\begin{array}{l}\text { yanna.shen@nih.go } \\
\text { v }\end{array}$ & & $\begin{array}{l}\text { National Library of } \\
\text { Medicine } \\
\text { National Institutes } \\
\text { of Health } \\
8600 \text { Rockville } \\
\text { Pike, Bldg 38A, } \\
\text { Rm 9N912A } \\
\text { Bethesda, MD } \\
20894\end{array}$ & & \\
\hline Slepski, Lynn & $\begin{array}{l}\text { Department of } \\
\text { Transportation }\end{array}$ & $\begin{array}{l}\text { Office of the } \\
\text { Secretary }\end{array}$ & $\begin{array}{l}\text { lynn.slepski@dot.g } \\
\text { ov }\end{array}$ & $202-366-0533$ & & $\begin{array}{l}\text { Senior Public } \\
\text { Health Advisor }\end{array}$ & \\
\hline Smith?, Robert & $\begin{array}{l}\text { University of } \\
\text { Ottawa }\end{array}$ & $\begin{array}{l}\text { Department of } \\
\text { Mathematics }\end{array}$ & $\begin{array}{l}\text { rsmith43@uottawa. } \\
\text { ca }\end{array}$ & $\begin{array}{l}6135625800 \\
\times 3864\end{array}$ & $\begin{array}{l}585 \text { King Edward } \\
\text { Ave } \\
\text { Ottawa, ON K1S } \\
\text { 0S1 } \\
\text { Canada }\end{array}$ & Asst Professor & $\begin{array}{l}\text { http://mysite.scienc } \\
\text { e.uottawa.ca/rsmith } \\
43 /\end{array}$ \\
\hline Stuart, Amy L. & $\begin{array}{l}\text { University of South } \\
\text { Florida }\end{array}$ & $\begin{array}{l}\text { Dept of } \\
\text { Environmental \& } \\
\text { Occupational } \\
\text { Health }\end{array}$ & $\begin{array}{l}\text { astuart@hsc.usf.ed } \\
\text { u }\end{array}$ & (813) 974-6632 & $\begin{array}{l}\text { University of South } \\
\text { Florida } \\
13201 \text { Bruce B. } \\
\text { Downs Blvd., } \\
\text { MDC-56 } \\
\text { Tampa, FL } 33612\end{array}$ & Associate Professor & $\begin{array}{l}\text { www.eng.usf.edu/ } \\
\text { als }\end{array}$ \\
\hline Svensson, Kerstin & $\begin{array}{l}\text { Swedish Research } \\
\text { Defense Agency }\end{array}$ & $\begin{array}{l}\text { Department of } \\
\text { NBC-Analysis }\end{array}$ & $\begin{array}{l}\text { kerstin.svensson@f } \\
\text { oi.se }\end{array}$ & & $\begin{array}{l}\text { Department of } \\
\text { NBC-Analysis } \\
\text { Swedish Research } \\
\text { Defense Agency } \\
\text { SE-901 } 82 \text { Umea } \\
\text { Sweden }\end{array}$ & & \\
\hline
\end{tabular}


Biosurveillance Modelers and Stakeholders

\begin{tabular}{|c|c|c|c|c|c|c|c|}
\hline Name & Agency & Division & Email & Phone & Address & Position & Website(s) \\
\hline Tatem, Andy & $\begin{array}{l}\text { University of } \\
\text { Florida, NIH }\end{array}$ & $\begin{array}{l}\text { Emerging } \\
\text { Pathogens Institute } \\
\text { and Dept of } \\
\text { Geography, } \\
\text { Research and } \\
\text { Policy in Infectious } \\
\text { Disease Dynamics } \\
\text { Program }\end{array}$ & $\begin{array}{l}\text { Andy.Tatem@gmai } \\
\text { l.com; } \\
\text { atatem@ufl.edu }\end{array}$ & $352-273-9373$ & $\begin{array}{l}\text { Emerging } \\
\text { Pathogens Institute } \\
\text { University of } \\
\text { Florida } \\
\text { Gainesville, FL }\end{array}$ & $\begin{array}{l}\text { Associate } \\
\text { Professor, Fellow }\end{array}$ & $\begin{array}{l}\text { http://www.clas.ufl } \\
\text { /edu/users/atatem }\end{array}$ \\
\hline Teachman, Mark E & USDA/APHIS & Veterinary Services & $\begin{array}{l}\text { mark.e.teachman@ } \\
\text { aphis.usda.gov }\end{array}$ & 301-734-8908 & $\begin{array}{l}4700 \text { River Road, } \\
\text { Room 5B-03c } \\
\text { Riverdale, MD } \\
20737\end{array}$ & $\begin{array}{l}\text { Director } \\
\text { Interagency } \\
\text { Coordination, } \\
\text { National Center for } \\
\text { Animal Health } \\
\text { Emergency } \\
\text { Management, } \\
\text { USDA }\end{array}$ & \\
\hline Thomas, Carla & UC Davis & $\begin{array}{l}\text { National Plant } \\
\text { Diagnostic } \\
\text { Network, Western } \\
\text { Integrated Plant } \\
\text { Management } \\
\text { Center }\end{array}$ & $\begin{array}{l}\text { cthomas@ucdavis. } \\
\text { edu }\end{array}$ & $\begin{array}{l}530-752-7010 \\
530-304-0689\end{array}$ & $\begin{array}{l}\text { Western Plant } \\
\text { Diagnostic } \\
\text { Network } \\
\text { Department of } \\
\text { Plant Pathology } \\
\text { University of } \\
\text { California } \\
\text { Davis, CA }\end{array}$ & $\begin{array}{l}\text { Deputy Director, } \\
\text { Associate Director }\end{array}$ & \\
\hline $\begin{array}{l}\text { Tildesley, Michael, } \\
\text { J. }\end{array}$ & $\begin{array}{l}\text { University of } \\
\text { Warwick }\end{array}$ & $\begin{array}{l}\text { Department of } \\
\text { Biological Sciences } \\
\text { and Mathematics } \\
\text { Institute }\end{array}$ & $\begin{array}{l}\text { m.j.tildesley@war } \\
\text { wick.ac.uk }\end{array}$ & $44(0) 2476150207$ & $\begin{array}{l}\text { University of } \\
\text { Warwick } \\
\text { Gibbet Hill Road } \\
\text { Coventry CV4 7AL } \\
\text { UK }\end{array}$ & Assistant Professor & \\
\hline
\end{tabular}


Biosurveillance Modelers and Stakeholders

\begin{tabular}{|c|c|c|c|c|c|c|c|}
\hline Name & Agency & Division & Email & Phone & Address & Position & Website(s) \\
\hline Titball, Richard W. & $\begin{array}{l}\text { University of } \\
\text { Exeter, UK }\end{array}$ & $\begin{array}{l}\text { College of Life and } \\
\text { Environmental } \\
\text { Sciences }\end{array}$ & $\begin{array}{l}\text { R.W.Titball@exete } \\
\text { r.ac.uk }\end{array}$ & $44(0) 1392725157$ & $\begin{array}{l}\text { Geoffrey Pope } \\
\text { Building } \\
\text { Biosciences } \\
\text { College of Life and } \\
\text { Environmental } \\
\text { Sciences } \\
\text { University of } \\
\text { Exeter } \\
\text { Stocker Road } \\
\text { Exeter } \\
\text { EX4 4QD } \\
\text { UK }\end{array}$ & $\begin{array}{l}\text { Professor of } \\
\text { Molecular } \\
\text { Microbiology }\end{array}$ & \\
\hline $\begin{array}{l}\text { Van den Broek, } \\
\text { Jan Heesterbeek }\end{array}$ & $\begin{array}{l}\text { Utrecht University, } \\
\text { The Netherlands }\end{array}$ & $\begin{array}{l}\text { Veterinary } \\
\text { Medicine }\end{array}$ & $\begin{array}{l}\text { J.vandenBroek@sc } \\
\text { ience.ru.nl }\end{array}$ & & & & \\
\hline Wagner, Bruce & USDA & $\begin{array}{l}\text { Center for } \\
\text { Epidemiology } \\
\text { Animal Health }\end{array}$ & $\begin{array}{l}\text { bruce.a.wagner@a } \\
\text { phis.usda.gov }\end{array}$ & $970-494-7210$ & & $\begin{array}{l}\text { Director of } \\
\text { NAHMS }\end{array}$ & \\
\hline Wagner, Dave & $\begin{array}{l}\text { Northern Arizona } \\
\text { University }\end{array}$ & $\begin{array}{l}\text { Department of } \\
\text { Biological Sciences }\end{array}$ & $\begin{array}{l}\text { Dave.Wagner@nau } \\
\text {.edu }\end{array}$ & $928-523-0686$ & $\begin{array}{l}\text { Department of } \\
\text { Biological Sciences } \\
\text { Northern Arizona } \\
\text { University } \\
\text { PO Box } 5640 \\
\text { Flagstaff, AZ } \\
86011-5640\end{array}$ & Associate Professor & \\
\hline Wallace, Katherine & $\begin{array}{l}\text { Department of } \\
\text { Veterans Affairs }\end{array}$ & & $\begin{array}{l}\text { katherine.wallace@ } \\
\text { va.gov }\end{array}$ & & $\begin{array}{l}810 \text { Vermont Ave, } \\
\text { NW } \\
\text { Washington, DC } \\
20420\end{array}$ & Program Analyst & \\
\hline $\begin{array}{l}\text { Washington, } \\
\text { Michael }\end{array}$ & $\mathrm{HHS} / \mathrm{CDC}$ & $\begin{array}{l}\text { Preparedness } \\
\text { Modeling Unit, } \\
\text { Health Services } \\
\text { and Evaluation } \\
\text { Branch, NIP }\end{array}$ & $\begin{array}{l}\text { mtw4@cdc.gov; } \\
\text { mwashington@cdc. } \\
\text { gov }\end{array}$ & $\begin{array}{l}(770) \text { 488-3267; } \\
404-498-0602\end{array}$ & $\begin{array}{l}4770 \text { Buford Hwy, } \\
\text { NE, MS F-61, } \\
\text { Chamblee, GA } \\
30341\end{array}$ & $\begin{array}{l}\text { Deputy Director, } \\
\text { Preparedness } \\
\text { Modeling Unit }\end{array}$ & \\
\hline Weaver, Curtis & $\mathrm{HHS} / \mathrm{CDC}$ & $\begin{array}{l}\text { Office of } \\
\text { Surveillance, } \\
\text { Epidemiology and } \\
\text { Laboratory } \\
\text { Services, Public } \\
\text { Health Surveillance }\end{array}$ & atr8@cdc.gov & & $\begin{array}{l}\text { CDC } \\
\text { COTPER/BCU } \\
\text { Atlanta, GA } 30333 \\
\text { USA }\end{array}$ & $\begin{array}{l}\text { Acting Director of } \\
\text { Biosurveillance } \\
\text { Coordination } \\
\text { Activity }\end{array}$ & \\
\hline
\end{tabular}


Biosurveillance Modelers and Stakeholders

\begin{tabular}{|c|c|c|c|c|c|c|c|}
\hline Name & Agency & Division & Email & Phone & Address & Position & Website(s) \\
\hline & & $\begin{array}{l}\text { and Informatics } \\
\text { Program }\end{array}$ & & & & & \\
\hline Wein, Lawrence & Stanford University & $\begin{array}{l}\text { Graduate School of } \\
\text { Business }\end{array}$ & $\begin{array}{l}\text { wein_lawrence@gs } \\
\text { b.stanford.edu; } \\
\text { lwein@stanford.ed } \\
\text { u }\end{array}$ & 650.724 .1676 & $\begin{array}{l}\text { Stanford Graduate } \\
\text { School of Business } \\
655 \text { Knight Way } \\
\text { Stanford, CA } \\
94305-7298\end{array}$ & $\begin{array}{l}\text { Professor of } \\
\text { Management } \\
\text { Science }\end{array}$ & $\begin{array}{l}\text { http://faculty- } \\
\text { gsb.stanford.edu/w } \\
\text { ein/ }\end{array}$ \\
\hline Weir, Mark H. & $\begin{array}{l}\text { Michigan State } \\
\text { University }\end{array}$ & $\begin{array}{l}\text { Department of } \\
\text { Fisheries and } \\
\text { Wildlife, Center for } \\
\text { Advancing } \\
\text { Microbial Risk } \\
\text { Assessment }\end{array}$ & weirma@msu.edu & (517) 353-8524 & $\begin{array}{l}\text { Michigan State } \\
\text { University } \\
303 \text { Manly Miles } \\
\text { Building } \\
\text { 1405 South } \\
\text { Harrison } \\
\text { East Lansing, MI } \\
48824\end{array}$ & $\begin{array}{l}\text { Post-doctoral } \\
\text { fellow }\end{array}$ & \\
\hline White, Sharon & $\begin{array}{l}\text { Environmental } \\
\text { Protection Agency }\end{array}$ & & $\begin{array}{l}\text { white.sharon@epa. } \\
\text { gov }\end{array}$ & & & & \\
\hline Writer, Jim & DOD/NCMI & & $\begin{array}{l}\text { jwriter@ncmi.detri } \\
\text { ck.army.mil }\end{array}$ & & & & \\
\hline Xu, Rui & $\begin{array}{l}\text { Missouri } \\
\text { University of } \\
\text { Science and } \\
\text { Technology, Rolla, } \\
\text { MO }\end{array}$ & $\begin{array}{l}\text { Applied } \\
\text { Computational } \\
\text { Intelligence } \\
\text { Laboratory, Dept } \\
\text { of Electrical and } \\
\text { Computer } \\
\text { Engineering }\end{array}$ & rxu@mst.edu & (573) $341-6811$ & $\begin{array}{l}131 \text { Emerson } \\
\text { Electric Co. Hall, } \\
1870 \text { Miner Circle } \\
\text { Rolla, Missouri } \\
65409-0040\end{array}$ & Research Associate & \\
\hline Zhou, Yicang & $\begin{array}{l}\text { Xi'an Jiaotong } \\
\text { University, China }\end{array}$ & $\begin{array}{l}\text { Department of } \\
\text { Applied } \\
\text { Mathematics }\end{array}$ & $\begin{array}{l}\text { zhouyc@mail.xjtu. } \\
\text { edu.cn }\end{array}$ & & $\begin{array}{l}\text { Department of } \\
\text { Mathematics, Xi'an } \\
\text { Jiaotong } \\
\text { University, Xi'an, } \\
\text { 710049, P. R. } \\
\text { China }\end{array}$ & & \\
\hline
\end{tabular}





\section{Appendix B}

\section{Client-Identified Source Lists for Agents, Toxins, and Pathogens of Interest ${ }^{1}$}

\begin{tabular}{|c|c|c|}
\hline List Name & List Location & NBIC Target Domains \\
\hline $\begin{array}{l}\text { HHS and USDA Select } \\
\text { Agents and Toxins }\end{array}$ & $\begin{array}{l}\text { http://www.selectagents.gov/reso } \\
\text { urces/List_of_Select_Agents_and } \\
\text { Toxins 2012-12-4.pdf }\end{array}$ & Human, Animal, Plant, Food \\
\hline $\begin{array}{l}\text { CDC - The Top } 5 \text { Causes } \\
\text { of Waterborne Outbreaks } \\
\text { in Private Groundwater } \\
\text { Wells }\end{array}$ & $\begin{array}{l}\text { http://www.cdc.gov/healthywater/ } \\
\underline{\text { drinking/private/wells/diseases.ht }}\end{array}$ & Human, Environment, Food \\
\hline $\begin{array}{l}\text { EPA - Regulated } \\
\text { Microorganisms } \\
\text { (pathogens - excludes } \\
\text { indicator organisms) }\end{array}$ & $\begin{array}{l}\underline{\text { http://water.epa.gov/drink/contam }} \\
\underline{\text { inants/index.cfm\#Microorganism }}\end{array}$ & Human, Environment, Food \\
\hline $\begin{array}{l}\text { CDC - Bioterrorism } \\
\text { Agents/Diseases }\end{array}$ & $\begin{array}{l}\text { http://www.bt.cdc.gov/agent/agen } \\
\text { tlist-category.asp }\end{array}$ & $\begin{array}{l}\text { Human, Animal, Environment, } \\
\text { Food }\end{array}$ \\
\hline $\begin{array}{l}\text { CDC - Healthcare- } \\
\text { Associated Infections } \\
\text { (HAIs) }\end{array}$ & $\begin{array}{l}\text { http://www.cdc.gov/HAI/organis } \\
\text { ms/organisms.html }\end{array}$ & Human, Food \\
\hline $\begin{array}{l}\text { CDC - List of Nationally } \\
\text { Notifiable Conditions }\end{array}$ & $\begin{array}{l}\frac{\mathrm{http}: / / \text { wwwn.cdc.gov/nndss/docu }}{\text { ment/2012_Case\%20Definitions. }} \\
\text { pdf }\end{array}$ & $\begin{array}{l}\text { Human, Animal, Environment, } \\
\text { Food }\end{array}$ \\
\hline $\begin{array}{l}\text { USDA - National Animal } \\
\text { Health Reportable } \\
\text { Disease List }\end{array}$ & $\begin{array}{l}\text { http://www.aphis.usda.gov/anima } \\
\text { 1_health/nahrs/downloads/2011_n } \\
\text { ahrs dz list.pdf }\end{array}$ & $\begin{array}{l}\text { Human, Animal, Environment, } \\
\text { Food }\end{array}$ \\
\hline $\begin{array}{l}\text { USDA - Pathogens that } \\
\text { Threaten U.S. Agriculture }\end{array}$ & $\begin{array}{l}\text { http://www.ars.usda.gov/research } \\
\text { /docs.htm?docid=14271 }\end{array}$ & Food, Plant \\
\hline $\begin{array}{l}\text { Pests and Pathogens } \\
\text { Threatening North }\end{array}$ & $\begin{array}{l}\mathrm{http}: / / \mathrm{www} \cdot \text { dontmovefirewood.or } \\
\mathrm{g} /\end{array}$ & Food, Plant \\
\hline
\end{tabular}

\footnotetext{
${ }^{1}$ These lists were received from the client via email on December 13, 2012.
} 



\section{Appendix C}

\section{De-duplicated List of Agents, Toxins, and Pathogens of Interest}

\begin{tabular}{|c|c|c|}
\hline $\begin{array}{l}\text { List }(\mathbf{s}) \\
\text { Source }\end{array}$ & Disease or Agent Name & Synonyms, Include Disease/Agent Specified (; separated) \\
\hline 1 & Abrin & $\begin{array}{l}\text { Abrin; Abrin; abrin-a; Proteopedia 1abr; Abrin poisoning; rosary pea; jequirity } \\
\text { pea; Abrus precatorius }\end{array}$ \\
\hline 5 & Acinetobacter & Acinetobacter; Acinetobacter baumannii \\
\hline 1,7 & African horse sickness virus & African horse sickness virus; African horse sickness; AHSV; AHS \\
\hline 1,7 & African swine fever virus & African swine fever virus; African swine fever \\
\hline 1 & Akabane virus & Akabane virus; Akabane disease; Tinaroo virus; Sabo virus; Yaba-7 \\
\hline 9 & Alder Dieback & Alder Dieback; Phytophthora alni; alder die back \\
\hline 8,9 & Ambrosia beetle & Ambrosia beetle; Xyleborus glabratus; laurel wilt \\
\hline 6,7 & Anaplasmosis (Anaplasma marginale, A. centrale) & Anaplasmosis; Anaplasma marginale; Anaplasma centrale; gall sickness \\
\hline 9 & Asian Gypsy Moth & Asian Gypsy Moth; Lymantria dispar asiatica; Lymantria dispar japonica \\
\hline 9 & Asian Longhorned Beetle & $\begin{array}{l}\text { Asian Longhorned Beetle; Anoplophora glabripennis; Asian Longhorned } \\
\text { beetle }\end{array}$ \\
\hline 7 & Aujeszky's Disease (Pseudorabies) & Aujeszky's Disease; Pseudorabies; PRV \\
\hline 7 & $\begin{array}{l}\text { Avian chlamydiosis (psittacosis and ornithosis, Chlamydia } \\
\text { psittaci) }\end{array}$ & $\begin{array}{l}\text { Avian chlamydiosis; psittacosis; ornithosis; Chlamydia psittaci; avian } \\
\text { chlamydiosis }\end{array}$ \\
\hline 7 & Avian infectious bronchitis & Avian infectious bronchitis; IB \\
\hline 7 & Avian infectious laryngotracheitis & Avian infectious laryngotracheitis; ILT \\
\hline 1 & Avian influenza virus & $\begin{array}{l}\text { Avian influenza virus; highly pathogenic avian influenza virus; HPAI virus; } \\
\text { HPAI A(H5N1); bird flu }\end{array}$ \\
\hline 6,7 & Babesiosis & Babesiosis;_Babesia bovis; Babesia bigemina; Babesia microti \\
\hline $1,4,6,7$ & Bacillus anthracis & Bacillus anthracis; anthrax; woolsorter's disease; ragpicker's disease \\
\hline 1 & Bacillus anthracis Pasteur strain & Bacillus anthracis Pasteur strain \\
\hline
\end{tabular}




\begin{tabular}{|c|c|c|}
\hline $\begin{array}{l}\text { List(s) } \\
\text { Source }\end{array}$ & Disease or Agent Name & Synonyms, Include Disease/Agent Specified (; separated) \\
\hline 9 & Balsam Woolly Adelgid & Balsam Woolly Adelgid; Adelges piceae \\
\hline 9 & Banded Elm Bark Beetle & Banded Elm Bark Beetle; Scolytus schevyrewi \\
\hline 9 & Beech Bark Disease & Beech Bark Disease; Nectria coccinea var. faginata Lohman; beech scale \\
\hline 1,7 & Bluetongue virus (exotic) & Bluetongue virus exotic; bluetongue virus; BTV; catarrhal fever \\
\hline $1,4,6$ & Botulinum neurotoxin producing species of Clostridium* & $\begin{array}{l}\text { Botulinum neurotoxin producing species of Clostridium; Clostridium } \\
\text { botulinum; Clostridium butyricum; Clostridium baratii; Clostridium } \\
\text { argentinense; botulism }\end{array}$ \\
\hline 1,4 & Botulinum neurotoxins & $\begin{array}{l}\text { Botulinum neurotoxins; BoNT; botulinum toxin; botulinum toxin type A; } \\
\text { botulinum toxin type B; botulinum toxin type C1; botulinum toxin type D; } \\
\text { botulinum toxin type E; botulinum toxin type F; botulinum toxin type G; } \\
\text { BTX-A; BTX-C1; BTX-D; BTX-E; sausage poison; fatty poison }\end{array}$ \\
\hline 7 & $\begin{array}{l}\text { Bovine Genital Campylobacteriosis (Campylobacter fetus } \\
\text { venerealis) }\end{array}$ & $\begin{array}{l}\text { Bovine Genital Campylobacteriosis; Campylobacter fetus venerealis; bovine } \\
\text { venereal campylobacteriosis; B VC }\end{array}$ \\
\hline 1,7 & Bovine spongiform encephalopathy agent & $\begin{array}{l}\text { Bovine spongiform encephalopathy agent; bovine spongiform encephalopathy } \\
\text { prion; CJD prion; Bovine spongiform encephalopathy; BSE; variant } \\
\text { Creutzfeldt-Jakob disease; CJD; v-CJD; new variant Creutzfeld-Jakob disease; } \\
\text { nv-CJD; mad cow disease }\end{array}$ \\
\hline 7 & Bovine Tuberculosis (Mycobacterium bovis) & Bovine Tuberculosis; Mycobacterium bovis; Bovine TB \\
\hline 7 & Bovine viral diarrhea (BVD) & $\begin{array}{l}\text { Bovine viral diarrhea; BVD; pestivirus genus; BVDV; BVDV-1; BVDV-2; } \\
\text { hog cholera virus }\end{array}$ \\
\hline 9 & Bromeliad Weevil & Bromeliad Weevil; Metamasius callizona \\
\hline 9 & Brown Longhorned Spruce Beetle & Brown Longhorned Spruce Beetle; Tetropium fuscum \\
\hline 1,7 & Brucella abortus & $\begin{array}{l}\text { Brucella abortus; bovine brucellosis; brucellosis; Bang's disease; Crimean } \\
\text { fever; Gibraltar fever; Malta fever; Maltese fever; Mediterranean fever; rock } \\
\text { fever; undulant fever; contagious abortion; infectious abortion }\end{array}$ \\
\hline
\end{tabular}




\begin{tabular}{|c|c|c|}
\hline $\begin{array}{l}\text { List(s) } \\
\text { Source }\end{array}$ & Disease or Agent Name & Synonyms, Include Disease/Agent Specified (; separated) \\
\hline 1,7 & Brucella suis & $\begin{array}{l}\text { Brucella suis; brucellosis; Porcine brucellosis; Enzootic Abortion; Contagious } \\
\text { Abortion, Undulant Fever }\end{array}$ \\
\hline $1,4,6,7$ & Brucellosis (Brucella species) & Brucellosis (Brucella species) \\
\hline 1,7 & Brucellosis, Ovine and Caprine & $\begin{array}{l}\text { Brucellosis, Ovine; Brucellosis, Caprine; Brucella melitensis; Brucella ovis; } \\
\text { ovine epididymitis; Malta Fever }\end{array}$ \\
\hline 5 & Burkholderia cepacia & Burkholderia cepacia \\
\hline $1,4,7$ & Burkholderia mallei* & Burkholderia mallei; Pseudomonas mallei; glanders \\
\hline 1 & Burkholderia pseudomallei* & $\begin{array}{l}\text { Burkholderia pseudomallei; Pseudomonas pseudomallei; melioidosis; } \\
\text { Whitemore's disease }\end{array}$ \\
\hline 9 & Butternut Canker & Butternut Canker; Ophiognomonia clavigignenti-juglandacearum \\
\hline 9 & Cactus Moth & Cactus Moth; Cactoblastis cactorum; Prickly pear moth \\
\hline 1 & Camel pox virus & Camel pox virus; CMPV; Camelpox \\
\hline 2 & Campylobacter jejuni & $\begin{array}{l}\text { Campylobacter jejuni; campylobacteriosis; campy; campylobacter enteritis; } \\
\text { gastroenteriti; Campylobacter fetus subsp. Jejuni }\end{array}$ \\
\hline 8 & $\begin{array}{l}\text { Candidatus Liberibacter asiaticus, L. africanus, and } L \text {. } \\
\text { americanus }\end{array}$ & $\begin{array}{l}\text { Candidatus Liberibacter asiaticus; L. africanus; L. americanus; Citrus } \\
\text { greening disease; huanglongbing; yellow dragon disease }\end{array}$ \\
\hline 7 & Caprine arthritis and encephalitis (CAE) & $\begin{array}{l}\text { Caprine arthritis and encephalitis; CAE; CAEV; Caprine arthritis and } \\
\text { encephalitis virus }\end{array}$ \\
\hline 1 & Cercopithecine herpesvirus 1 (Herpes B virus) & $\begin{array}{l}\text { Cercopithecine herpesvirus 1; Herpes B virus; Herpesvirus simiae; Macacine } \\
\text { herpesvirus 1; Cercopithecine Herpesvirus 1; Herpes Simian B virus; Herpes B } \\
\text { virus; herpes B; monkey B virus; herpesvirus simiae; herpesvirus B; CHV-1; } \\
\text { CeHV-1; SHBV }\end{array}$ \\
\hline 6 & Chancroid & Chancroid; Haemophilus ducreyi \\
\hline 9 & Chestnut Blight & Chestnut Blight; Cryphonectria parasitica \\
\hline 9 & Chestnut Gall Wasp & Chestnut Gall Wasp; Dryocosmus kuriphilus \\
\hline 6 & Chlamydia trachomatis infection & Chlamydia trachomatis infection; Chlamydia trachomatis; chlamydia \\
\hline 6 & Cholera & Cholera; Vibrio cholera \\
\hline
\end{tabular}




\begin{tabular}{|c|c|c|}
\hline $\begin{array}{l}\text { List(s) } \\
\text { Source }\end{array}$ & Disease or Agent Name & Synonyms, Include Disease/Agent Specified (; separated) \\
\hline 8 & Citrus leprosis virus & Citrus leprosis virus; Nail-head rust; nail-head spot; scaly bark \\
\hline 9 & Citrus Longhorned Beetle & Citrus Longhorned Beetle; Anoplophora chinensis \\
\hline 1,7 & Classical swine fever virus & $\begin{array}{l}\text { Classical swine fever virus; classical swine fever; hog cholera; CSFV; pig } \\
\text { plague }\end{array}$ \\
\hline 5 & Clostridium difficile & Clostridium difficile; $\mathrm{CDF} ; \mathrm{C}$ diff \\
\hline 1,4 & Clostridium perfringens epsilon toxin & $\begin{array}{l}\text { Clostridium perfringens, epsilon toxin; Clostridium perfringens enteritis; } \\
\text { Clostridium enterotoxin poisoning }\end{array}$ \\
\hline 5 & Clostridium sordellii & Clostridium sordellii \\
\hline 1,6 & Coccidioides posadasii/Coccidioides immitis & $\begin{array}{l}\text { Coccidioides posadasii; Coccidioides immitis; coccidioidomycosis; Valley } \\
\text { Fever; San Joaquin Valley Fever; desert bumps; desert rheumatism; Posadas' } \\
\text { disease }\end{array}$ \\
\hline 9 & Common Pine Shoot Beetle & Common Pine Shoot Beetle; Tomicus piniperda \\
\hline 1 & $\begin{array}{l}\text { Conotoxins (Short, paralytic alpha conotoxins containing } \\
\text { the following amino acid sequence } \\
\text { X1CCX2PACGX3X4X5X6CX7) }\end{array}$ & $\begin{array}{l}\text { Conotoxins; short paralytic alpha conotoxins; amino acid sequence } \\
\text { X1CCX2PACGX3X4X5X6CX7; } \alpha \text {-conotoxin; } \delta \text {-conotoxin; } \kappa \text {-conotoxin; } \mu \text { - } \\
\text { conotoxin; } \omega \text {-conotoxin; alpha conotoxin; delta conotoxin; kappa conotoxin; } \\
\text { mu conotoxin; omega conotoxin }\end{array}$ \\
\hline 7 & $\begin{array}{l}\text { Contagious agalactia (Mycoplasma agalactiae, } M . \\
\text { Capricolum capricolum, } M \text {. putrefaciens, } M . \text { mycoides } \\
\text { mycoides, } M . \text { mycoides mycoides } L C \text { ) }\end{array}$ & $\begin{array}{l}\text { Contagious agalactia; Mycoplasma agalactiae; Mycoplasma Capricolum } \\
\text { capricolum; Mycoplasma putrefaciens; Mycoplasma mycoides mycoides; } \\
\text { Mycoplasma mycoides mycoides LC }\end{array}$ \\
\hline 7 & $\begin{array}{l}\text { Contagious bovine pleuropneumonia (Mycoplasma } \\
\text { mycoides mycoides) }\end{array}$ & Contagious bovine pleuropneumonia; Mycoplasma mycoides mycoides; CBPP \\
\hline 7 & $\begin{array}{l}\text { Contagious caprine pleuropneumonia (Mycoplasma } \\
\text { capricolum capripneumoniae) }\end{array}$ & $\begin{array}{l}\text { Contagious caprine pleuropneumonia; Mycoplasma capricolum } \\
\text { capripneumoniae; Contagious caprine pleuropneumonia; CCPP; Mycoplasma } \\
\text { strain F38 }\end{array}$ \\
\hline 7 & Contagious equine metritis (Taylorella equigenitalis) & Contagious equine metritis; Taylorella equigenitalis; CEM \\
\hline 8 & Cotton leaf curl virus & Cotton leaf curl virus; cotton leaf curl; Cotton leaf curl geminivirus; CLCuV \\
\hline $1,4,6,7$ & Coxiella burnetii & Coxiella burnetii; $\mathrm{Q}$ fever; Query fever \\
\hline
\end{tabular}




\begin{tabular}{|c|c|c|}
\hline $\begin{array}{l}\text { List(s) } \\
\text { Source }\end{array}$ & Disease or Agent Name & Synonyms, Include Disease/Agent Specified (; separated) \\
\hline 3 & coxsackieviruses A & coxsackieviruses A; Hand, foot, and mouth disease; HFMD; Cosackie A virus \\
\hline 3 & coxsackieviruses B & coxsackieviruses B; Coxsackie B virus \\
\hline 7 & Crayfish plague (Aphanomyces astaci) & Crayfish plague; Aphanomyces astaci \\
\hline 1,7 & Crimean-Congo hemorrhagic fever virus & $\begin{array}{l}\text { Crimean-Congo hemorrhagic fever virus; Crimean-Congo hemorrhagic fever; } \\
\text { CCHF }\end{array}$ \\
\hline 8 & Cronartium flaccidum & $\begin{array}{l}\text { Cronartium flaccidum; Scots pine blister rust; Cronartium rust; blister rust; } \\
\text { pine-stem rust; resin canker; resin top disease; two-needle pine blister rust }\end{array}$ \\
\hline 3,6 & Cryptosporidiosis & $\begin{array}{l}\text { Cryptosporidiosis; Cryptosporidium enteritis; crypto; Cryptosporidium } \\
\text { parvum }\end{array}$ \\
\hline 9 & Cycad Aulacaspis Scale & Cycad Aulacaspis Scale; Aulacaspis yasumatsui \\
\hline 6 & Cyclosporiasis & Cyclosporiasis; Cyclospora cayetanensis; traveller's diarrhea; cyclospora \\
\hline 7 & $\begin{array}{l}\text { Cysticercosis (Cysticercus cellulosae, metacestode stage } \\
\text { of Taenia solium) }\end{array}$ & $\begin{array}{l}\text { Cysticercosis; Cysticercus cellulosae; metacestode stage of Taenia solium; } \\
\text { pork tapeworm; cysticercosis; neurosysticercosis; opthalmic cysticercosis; } \\
\text { subcutaneous cysticercosis }\end{array}$ \\
\hline 6 & Dengue virus infections & $\begin{array}{l}\text { Dengue virus infections; dengue virus; dengue fever; dengue hemorrhagic } \\
\text { fever; dengue infection }\end{array}$ \\
\hline 1 & Diacetoxyscirpenol & Diacetoxyscirpenol; 4,15-diacetoxyscirpenol \\
\hline 6 & Diphtheria & Diphtheria; Corynebacterium diphtheriae \\
\hline 9 & Dogwood Anthracnose Disease & Dogwood Anthracnose ; Discula destructiva \\
\hline 7 & Dourine (Trypanosoma equiperadum) & Dourine; Trypanosoma equiperadum \\
\hline 7 & Duck viral hepatitis & Duck viral hepatitis; duck hepatitis \\
\hline 9 & Dutch Elm Disease & $\begin{array}{l}\text { Dutch Elm Disease; Ophiostoma ulmi; Ophiostoma himal-ulmi; Ophiostoma } \\
\text { novo-ulmi }\end{array}$ \\
\hline 2 & E. coli $0157: \mathrm{H} 7$ & $\begin{array}{l}\text { E. coli } 0157: \mathrm{H} 7 \text {; Escherichia coli; E. coli; Shiga toxin-producing E. coli; } \\
\text { STEC; enterohemorrhagic E. coli; EHEC; E. coli gastroenteritis }\end{array}$ \\
\hline 1 & Eastern Equine Encephalitis virus & Eastern Equine Encephalitis virus; EEEV; EEE \\
\hline
\end{tabular}




\begin{tabular}{|c|c|c|}
\hline $\begin{array}{l}\text { List(s) } \\
\text { Source }\end{array}$ & Disease or Agent Name & Synonyms, Include Disease/Agent Specified (; separated) \\
\hline 1 & Ebola virus & $\begin{array}{l}\text { Ebola virus; Ebola; Ebola hemorrhagic fever; EHF; Ebola virus; EBOV; Zaire } \\
\text { ebolavirus; ZEBOV; Sudan ebolavirus; SEBOV; Reston ebolavirus; REBOV; } \\
\text { Cote d'Ivoire ebolavirus; CIEBOV; Bundibugyo ebolavirus }\end{array}$ \\
\hline 7 & Echinococcosis / hydatidosis & $\begin{array}{l}\text { Echinococcosis; hydatidosis; Echinococcosis granulosus; Echinococcosis } \\
\text { multilocularis; Echinococcosis oligarthrus; Echinococcosis vogeli; } \\
\text { Echinococcosis shiquicus; hydatid disease; cycstic echinococcosis }\end{array}$ \\
\hline 3 & echoviruses & echoviruses; Enteric Cytopathic Human Orphan virus \\
\hline 1 & Ehrlichia ruminantium (Heartwater) & Ehrlichia ruminantium; Heartwater; Cowdria ruminatum; cowdriosis \\
\hline 6 & Ehrlichiosis & $\begin{array}{l}\text { Ehrlichiosis; Human monocytic ehrlichiosis; HME; Human granulocytic } \\
\text { ehrlichiosis; HGE; Human granulocytic anaplasmosis; HGA }\end{array}$ \\
\hline 9 & Emerald Ash Borer & Emerald Ash Borer; Agrilus planipennis \\
\hline 5 & Enterobacteriaceae (carbapenem-resistant) & Enterobacteriaceae; carbapenem-resistant; gram negative bacteria \\
\hline 3 & enteroviruses & enteroviruses \\
\hline 7 & $\begin{array}{l}\text { Enzootic abortion of ewes (Ovine psittacosis, Chlamydia } \\
\text { psittaci) }\end{array}$ & $\begin{array}{l}\text { Enzootic abortion of ewes; Ovine psittacosis; Chlamydia psittaci; Enzootic } \\
\text { abortion of ewes }\end{array}$ \\
\hline 7 & Enzootic bovine leukosis (BLV) & Enzootic bovine leukosis; BLV \\
\hline 7 & Epizootic hematopoietic necrosis & Epizootic hematopoietic necrosis; EHN; EHNV \\
\hline 7 & Epizootic hemorrhagic disease (EHD) & Epizootic hemorrhagic disease; EHD \\
\hline 7 & Epizootic ulcerative syndrome & Epizootic ulcerative syndrome; EUS \\
\hline 7 & Equine herpesvirus myeloencephalopathy (EHV1 - EHM) & Equine herpesvirus myeloencephalopathy; EHV1; EHV1-EHM \\
\hline 7 & Equine infectious anemia & Equine infectious anemia; EIA; EIAV \\
\hline 7 & Equine influenza (Virus Type A) & Equine influenza (Virus Type A); horse flu \\
\hline 7 & $\begin{array}{l}\text { Equine piroplasmosis (Babesiosis, Babesia [Piroplasma] } \\
\text { equi, B. caballi) }\end{array}$ & $\begin{array}{l}\text { Equine piroplasmosis (Babesiosis, Babesia [Piroplasma] equi, Babesia } \\
\text { caballi); Equine piroplasmosis; EP }\end{array}$ \\
\hline
\end{tabular}




\begin{tabular}{|c|c|c|}
\hline $\begin{array}{l}\text { List(s) } \\
\text { Source }\end{array}$ & Disease or Agent Name & Synonyms, Include Disease/Agent Specified (; separated) \\
\hline 7 & Equine rhinopneumonitis (EHV 1 and 4) & $\begin{array}{l}\text { Equine rhinopneumonitis; Equine viral rhinopneumonitis; EHV1; EHV4; } \\
\text { Equine abortion virus }\end{array}$ \\
\hline 7 & Equine viral arteritis (EVA) & Equine viral arteritis; EVA \\
\hline 9 & Erythrina Gall Wasp & Erythrina Gall Wasp; Quadrastichus erythrinae \\
\hline 9 & Eurasian Nun Moth & Eurasian Nun Moth; Lymantria monacha \\
\hline 9 & European Gypsy Moth & European Gypsy Moth; Lymantria dispar; EGM \\
\hline 9 & European Larch Canker & European Larch Canker; Lachnellula (Dasyscypha) willkommii (Hartig) \\
\hline 9 & European Oak Bark Beetle & European Oak Bark Beetle; Scolytus intricatus \\
\hline 9 & European Spruce Bark Beetle & European Spruce Bark Beetle; Ips typographus L. \\
\hline 1,7 & Foot and mouth disease virus & $\begin{array}{l}\text { Foot-and-mouth disease virus; Aphtae epizooticae; FMDV; FMD; FMD } \\
\text { serotype }\end{array}$ \\
\hline 7 & Fowl cholera (Pasteurella multocida) & Fowl cholera; Pasteurella multocida; Pasteurellosis \\
\hline 7 & Fowl typhoid (Salmonella gallinarum) & Fowl typhoid; Salmonella gallinarum \\
\hline $1,4,6,7$ & Francisella tularensis* & $\begin{array}{l}\text { Francisella tularensis; tularemia; Pahvant Valley plague; rabbit fever; deer fly } \\
\text { fever; Ohara's fever }\end{array}$ \\
\hline 9 & Pine Pitch Canker & Pine Pitch Canker; Fusarium circinatum \\
\hline 9 & Fusarium fungus, unnamed & Fusarium fungus; Fusarium spp. \\
\hline 8 & Geosmithia sp. & Geosmithia sp.; Thousand cankers disease; Geosmithia morbida \\
\hline $2,3,6$ & Giardia & Giardia; Giardia intestinalis; Giardia lamblia; Giardia duodenali; Giardiasis \\
\hline 1,7 & Goat pox virus & Goat pox virus; goatpox; goat pox; Variola caprina \\
\hline 9 & Golden Haired Pine Bark Beetle & $\begin{array}{l}\text { Golden Haired Pine Bark Beetle; Hylurgus ligniperda; Golden-haired bark } \\
\text { beetle }\end{array}$ \\
\hline 9 & Goldspotted oak borer & Goldspotted oak borer; Agrilus auroguttatus; GSOB \\
\hline 6 & Gonorrhea & Gonorrhea; the clap; Neisseria gonorrhoeae \\
\hline 7 & Gyrodactylosis & Gyrodactylosis; Gyrodactylus salaris \\
\hline 6 & Haemophilus influenzae, invasive disease & $\begin{array}{l}\text { Haemophilus influenza; invasive disease; Haemophilus influenzae type B; Hib; } \\
\text { Pfeiffer's bacillus; Bacillus influenzae }\end{array}$ \\
\hline
\end{tabular}




\begin{tabular}{|c|c|c|}
\hline $\begin{array}{l}\text { List(s) } \\
\text { Source }\end{array}$ & Disease or Agent Name & Synonyms, Include Disease/Agent Specified (; separated) \\
\hline 6 & Hansen's disease (leprosy) & Hansen's disease; leprosy \\
\hline 4,6 & Hantavirus pulmonary syndrome & Hantavirus pulmonary syndrome; Hantavirus; HPS \\
\hline 8 & Harpophora maydis & Harpophora maydis; late wilt of maize \\
\hline 9 & Harrisia cactus mealybug & Harrisia cactus mealybug; Hypogeococcus pungens \\
\hline 7 & Heartwater (Cowdria ruminantium) & $\begin{array}{l}\text { Heartwater; Cowdria ruminantium; Cowdria ruminatum; Ehrlichia } \\
\text { ruminantium; Cowdriosis; nintas; ehrlichiosis }\end{array}$ \\
\hline 9 & Hemlock Woolly Adelgid & Hemlock Woolly Adelgid; Adelges tsugae \\
\hline 6 & Hemolytic uremic syndrome, post-diarrheal & $\begin{array}{l}\text { Hemolytic uremic syndrome, post-diarrheal; Hemolytic uremic syndrome; } \\
\text { HUS }\end{array}$ \\
\hline 7 & $\begin{array}{l}\text { Hemorrhagic septicemia (Pasteurella multocida, serotypes } \\
\text { B/Asian or E/African) }\end{array}$ & $\begin{array}{l}\text { Hemorrhagic septicemia; Pasteurella multocida serotype B/Asian; Pasteurella } \\
\text { multocida serotype E/African; Shipping Fever; Pasteurella multocida; HS }\end{array}$ \\
\hline 1 & Hendra virus & Hendra virus; Equine Morbilivirus; Henipavirus; $\mathrm{HeV}$ \\
\hline 2,6 & Hepatitis A & Hepatitis A; HAV; hep A \\
\hline 5,6 & Hepatitis B (acute, chronic or perinatal) & Hepatitis B; HBV; hep B \\
\hline 5,6 & Hepatitis C & Hepatitis C; HCV; hep C \\
\hline 8 & Heterodera spp. and Meloidogyne spp. & Heterodera spp.; Meloidogyne spp.; cyst and root-knot nematodes \\
\hline 7 & Highly pathogenic avian influenza & Highly pathogenic avian influenza; HPAI \\
\hline 5,6 & Human Immunodeficiency Virus (HIV) & Human Immunodeficiency Virus; HIV; AIDS \\
\hline 7 & Infection with abalone herpes-like virus & $\begin{array}{l}\text { Infection with abalone herpes-like virus; AbHV; abalone viral ganglioneuritis; } \\
\text { AVG }\end{array}$ \\
\hline 7 & Infection with Bonamia exitiosa & Bonamia exitiosa \\
\hline 7 & Infection with Bonamia ostreae & Bonamia ostreae; bonamiosis \\
\hline 7 & Infection with Marteilia refringens & Marteilia refringens; Aber disease; marteiliosis \\
\hline 7 & Infection with Perkinsus marinus & Perkinsus marinus; Dermo; Perkinsosis \\
\hline 7 & Infection with Perkinsus olseni & Perkinsus olseni; Perkinsus atlanticus \\
\hline 7 & Infection with Xenohaliotis californiensis & Xenohaliotis californiensis; withering syndrome; abalone rickettsiosis \\
\hline
\end{tabular}




\begin{tabular}{|c|c|c|}
\hline $\begin{array}{l}\text { List(s) } \\
\text { Source }\end{array}$ & Disease or Agent Name & Synonyms, Include Disease/Agent Specified (; separated) \\
\hline 7 & $\begin{array}{l}\text { Infectious bovine rhinotracheitis/infectious pustular } \\
\text { vulvovaginitis (IBR/IPV) }\end{array}$ & $\begin{array}{l}\text { Infectious bovine rhinotracheitis/infectious pustular vulvovaginitis; IBR/IPV; } \\
\text { Bovine herpesvirus 1; bovine rhinotracheitis; infectious pustular vulvovaginitis }\end{array}$ \\
\hline 7 & Infectious bursal disease (Gumboro disease) & Infectious bursal disease; Gumboro disease; IMB; IBDV \\
\hline 7 & Infectious hematopoietic necrosis & $\begin{array}{l}\text { Infectious hematopoietic necrosis; IHN; Infectious hematopoietic necrosis } \\
\text { virus; IHNV }\end{array}$ \\
\hline 7 & Infectious hypodermal and haematopoietic necrosis & $\begin{array}{l}\text { Infectious hypodermal and haematopoietic necrosis; IHHN; Infectious } \\
\text { hypodermal and haematopoietic necrosis virus; IHHNV }\end{array}$ \\
\hline 7 & Infectious myonecrosis & Infectious myonecrosis; IMN; IMNV; Infectious myonecrosis virus \\
\hline 7 & Infectious salmon anemia & $\begin{array}{l}\text { Infectious salmon anemia; ISA; ISAV; European genotype (genotype I); North } \\
\text { American genotype (genotype II) }\end{array}$ \\
\hline 5 & Influenza & Influenza; flu; H1N1; H3N2; Influenza A; Influenza B; Influenza C \\
\hline 6 & Influenza-associated mortality, pediatric & Influenza-associated mortality, pediatric \\
\hline 1,7 & Japanese encephalitis virus & Japanese encephalitis virus; JEV; Japanese encephalitis; JE \\
\hline 5 & Klebsiella & Klebsiella; Klebsiella pneumoniae \\
\hline 7 & Koi herpesvirus disease & $\begin{array}{l}\text { Koi herpesvirus disease; Koi herpes virus; KHV; cyprinid herpesvirus-3; } \\
\text { CyHV-3 }\end{array}$ \\
\hline 9 & Larch Casebearer & Larch Casebearer; Coleophora laricella \\
\hline 9 & Larger Pine Shoot Beetle & Larger Pine Shoot Beetlecommon pine shoot beetle; Tomicus piniperda \\
\hline 1 & Lassa fever virus & Lassa fever virus; Lassa fever; Lassa viral hemorrhagic fever \\
\hline 8,9 & Laurel wilt & Laurel wilt; Raffaelea lauricola; Laurel wilt of avocado; Laurel wilt of redbay \\
\hline 6 & Lead, exposure screening test result & Lead, exposure screening test result \\
\hline 3,6 & Legionellosis / Legionella & $\begin{array}{l}\text { Legionellosis; Legionella; Legionella pneumophila; Legionnaire's disease; } \\
\text { Pontiac fever }\end{array}$ \\
\hline
\end{tabular}




\begin{tabular}{|c|c|c|}
\hline $\begin{array}{l}\text { List(s) } \\
\text { Source }\end{array}$ & Disease or Agent Name & Synonyms, Include Disease/Agent Specified (; separated) \\
\hline 7 & Leptospirosis & $\begin{array}{l}\text { Leptospirosis; Leptospira; Weil disease; Icterohemorrhagic fever; Swineherd's } \\
\text { disease; Rice-field fever; Cane-cutter fever; Swamp fever; Mud fever; } \\
\text { Hemorrhagic jaundice; Stuttgart disease; Canicola fever }\end{array}$ \\
\hline 6 & Listeriosis & Listeriosis; Listeria monocytogenes \\
\hline 9 & Lobate Lac Scale & Lobate Lac Scale; Paratachardina pseudolobata \\
\hline 7 & Low pathogenic avian influenza (H5 or H7 subtypes) & $\begin{array}{l}\text { Low pathogenic avian influenza; Avian influenza H5; Avian influenza H7; } \\
\text { LPAI }\end{array}$ \\
\hline 1 & Lujo virus & Lujo virus; Lujo hemorrhagic fever; Lujo fever \\
\hline 1,7 & Lumpy skin disease virus & Lumpy skin disease virus; Lumpy skin disease; LSDV \\
\hline 6 & Lyme disease & Lyme disease; Borrelia burgdorferi \\
\hline 7 & Maedi-visna / ovine progressive pneumonia & $\begin{array}{l}\text { Maedi-visna/ovine progressive pneumonia; ovine progressive pneumonia; } \\
\text { progressive pneumonia; Maedi; Zwoegersiekte; La bouhite; Graaff-Reinet } \\
\text { disease; Marsh's progressive pneumonia }\end{array}$ \\
\hline 8 & Magnaporthe grisea & $\begin{array}{l}\text { Magnaporthe grisea; Wheat blast; rice blast; rice rotten neck; rice seedling } \\
\text { blight; blast of rice; oval leaf spot of graminea; pitting disease; ryegrass blast; } \\
\text { Johnson spot; blast disease, blight disease }\end{array}$ \\
\hline 6 & Malaria & $\begin{array}{l}\text { Malaria; Plasmodium falciparum; Plasmodium vivax; Plasmodium malariae; } \\
\text { Plasmodium ovale; Plasmodium knowlesi }\end{array}$ \\
\hline 1,7 & $\begin{array}{l}\text { Malignant catarrhal fever virus (Alcelaphine herpesvirus } \\
\text { type 1) }\end{array}$ & $\begin{array}{l}\text { Malignant catarrhal fever virus (Alcelaphine herpesvirus type 1); Malignant } \\
\text { catarrhal fever virus; Alcelaphine herpes virus 1; AIHV-1; Ovine herpes virus } \\
\text { 2; OHV-2; malignant catarrhal fever; bovine malignant catarrhal fever; BMCF }\end{array}$ \\
\hline 1 & Marburg virus & $\begin{array}{l}\text { Marburg virus; Lake Victoria Marburg virus; Marburg hemorrhagic fever; } \\
\text { MHF }\end{array}$ \\
\hline 7 & Marek's Disease & Marek's Disease; Gallid herpesvirus 2; GaHV-2; Marek's disease virus; MDV \\
\hline 6 & Measles & Measles; measles virus \\
\hline 9 & Mediterranean Pine Engraver Beetle & Mediterranean Pine Engraver Beetle; Orthotomicus erosus \\
\hline
\end{tabular}




\begin{tabular}{|c|c|c|}
\hline $\begin{array}{l}\text { List(s) } \\
\text { Source }\end{array}$ & Disease or Agent Name & Synonyms, Include Disease/Agent Specified (; separated) \\
\hline 4 & Melioidosis & Melioidosis; Burkholderia pseudomallei; Pseudomonas pseudomallei \\
\hline 1 & Menangle virus & Menangle virus \\
\hline 6 & Meningococcal disease (Neisseria meningitides) & $\begin{array}{l}\text { Meningococcal disease; Neisseria meningitides; bacterial meningitis; } \\
\text { meningococcemia }\end{array}$ \\
\hline 5 & Methicillin-resistant Staphylococcus aureus & Methicillin-resistant Staphylococcus aureus; Staphylococcus aureus; MRSA \\
\hline 1 & Monkeypox virus & Monkeypox virus; monkeypox \\
\hline 6 & Mumps & Mumps; mumps virus; epidemic parotitis \\
\hline 5 & Mycobacterium abscessus & Mycobacterium abscessus \\
\hline 1 & Mycoplasma capricolum & $\begin{array}{l}\text { Mycoplasma capricolum; Mycoplasma capricolum subspecies } \\
\text { capripneumoniae; contagious caprine pleuropneumonia, mastitis and severe } \\
\text { arthritis }\end{array}$ \\
\hline 1 & Mycoplasma mycoides & Mycoplasma mycoides \\
\hline 1 & $\begin{array}{l}\text { Mycoplasma mycoides subspecies mycoides small colony } \\
\text { (Mmm SC) (contagious bovine pleuropneumonia) }\end{array}$ & $\begin{array}{l}\text { Mycoplasma mycoides subspecies mycoides small colony ( } \mathrm{Mmm} \mathrm{SC} \text { ) } \\
\text { (contagious bovine pleuropneumonia); contagious bovine pleuropneumonia }\end{array}$ \\
\hline 7 & Mycoplasmosis (M. gallisepticum) & Mycoplasmosis; Mycoplasma gallisepticum; mycoplasmosis \\
\hline 7 & Mycoplasmosis (M. synoviae) & Mycoplasmosis; Mycoplasma synoviae; mycoplasmosis \\
\hline 7 & Nairobi sheep disease & Nairobi sheep disease; Nairobi sheep disease virus; NSDV \\
\hline 7 & Necrotizing hepatopancreatitis & $\begin{array}{l}\text { Necrotizing hepatopancreatitis; Necrotising hepatopancreatitis; NHP; Texas } \\
\text { pond mortality syndrome; TPMS; Texas necrotizing hepatopancreatitis; } \\
\text { TNHP; Peru necrotizing hepatopancreatitis; PNHP }\end{array}$ \\
\hline 1,7 & Newcastle disease virus & $\begin{array}{l}\text { Newcastle disease virus; Virulent Newcastle disease virus 1; Newcastle } \\
\text { disease virus; NDV; Newcastle disease; velogenic Newcastle disease; } \\
\text { mesogenic Newcastle disease }\end{array}$ \\
\hline
\end{tabular}




\begin{tabular}{|c|c|c|}
\hline $\begin{array}{l}\text { List(s) } \\
\text { Source }\end{array}$ & Disease or Agent Name & Synonyms, Include Disease/Agent Specified (; separated) \\
\hline $1,4,7$ & Nipah virus & Nipah virus; Nipah virus encephalitis \\
\hline 5 & Norovirus & Norovirus; stomach flu; winter vomiting bug; Norwalk-like virus \\
\hline 6 & Novel Influenza A virus infection & Novel Influenza A virus infection; influenza \\
\hline 9 & Oak Dieback & Oak Dieback; Phytophtora quercina \\
\hline 9 & Ohi'a Rust & Ohi'a Rust; Puccinia psidii Winter; Puccinia rust \\
\hline 7 & Paratuberculosis & $\begin{array}{l}\text { Paratuberculosis; Mycobacterium avium paratuberculosis; MAP; Johne's } \\
\text { disease }\end{array}$ \\
\hline 1,8 & $\begin{array}{l}\text { Peronosclerospora philippinensis (Peronosclerospora } \\
\text { sacchari) }\end{array}$ & $\begin{array}{l}\text { Peronosclerospora philippinensis; Peronosclerospora sacchari; Phillipine } \\
\text { downy mildew; Philippine downy mildew of maize; PDM; Brown Stripe } \\
\text { downy mildew of corn }\end{array}$ \\
\hline 6 & Pertussis & Pertussis; Bordetella pertussis; Bordetella parapertussis; Whooping cough \\
\hline 1,7 & Peste des petits ruminants & $\begin{array}{l}\text { Peste des petits ruminants; Peste des petits ruminants virus; PPR; ovine } \\
\text { rinderpest; PPRV }\end{array}$ \\
\hline 1,8 & Phoma glycinicola (formerly Pyrenochaeta glycines) & $\begin{array}{l}\text { Phoma glycinicola; Red leaf blotch of soybean; Pyrenochaeta leaf spot; } \\
\text { Dactuliophora leaf spot; Pyrenochaeta leaf blotch; RLB; Pyrenochaeta } \\
\text { glycines; Dactuliophora glycines; Dactuliochaeata glycines of soybean }\end{array}$ \\
\hline 8,9 & Phytophthora kernoviae & Phytophthora kernoviae; Ramorum dieback; sudden oak death \\
\hline 9 & Phytophthora Root Rot & Phytophthora Root Rot; Phytophthora cinnamomi \\
\hline 9 & Pine Flat Bug & Pine Flat Bug; Aradus cinnamomeus Panzer \\
\hline 8 & plum pox virus (PPV) & plum pox virus; PPV; plum pox; Sharka; Sharka virus \\
\hline 3,6 & Poliovirus infection & $\begin{array}{l}\text { Poliovirus infection; polio; poliomyelitis; paralytic poliomyelitis; poliovirus; } \\
\text { PV }\end{array}$ \\
\hline 9 & Polyphagous shot hole borer & Polyphagous shot hole borer; Euwallacea sp.; Fusarium fungus \\
\hline
\end{tabular}




\begin{tabular}{|c|c|c|}
\hline $\begin{array}{l}\text { List(s) } \\
\text { Source }\end{array}$ & Disease or Agent Name & Synonyms, Include Disease/Agent Specified (; separated) \\
\hline 7 & Porcine reproductive and respiratory syndrome (PRRSV) & $\begin{array}{l}\text { Porcine reproductive and respiratory syndrome (PRRSV); PRRS virus; } \\
\text { PRRSV; porcine arterivirus; Blue ear pig disease; mystery swine disease }\end{array}$ \\
\hline 9 & Port-Orford-Cedar Root Disease & Port-Orford-Cedar Root Disease; Phytophthora lateralis \\
\hline 4,6 & Psittacosis & Psittacosis; Chlamydia psittaci; parrot fever \\
\hline 8 & Puccinia graminis f. sp. tritici & Puccinia graminis f. sp. tritici; Stem rust of wheat (Ug99); black rust \\
\hline 7 & Pullorum disease (Salmonella pullorum) & $\begin{array}{l}\text { Pullorum disease; Bacillary White Diarrhoea; Pullorum disease; Salmonella } \\
\text { pullorum; Salmonella }\end{array}$ \\
\hline 6,7 & Rabies & $\begin{array}{l}\text { Rabies; Rabies virus; Lyssavirus; Ephemerovirus; Vesiculovirus; Australian } \\
\text { bat virus; Mokola virus; Duvenhage virus; European bat virus 1; European bat } \\
\text { virus 2; Lagos bat virus }\end{array}$ \\
\hline 1,8 & Ralstonia solanacearum race 3 , biovar 2 & $\begin{array}{l}\text { Ralstonia solanacearum race 3, biovar 2; Ralstonia bacterial wilt of potato; } \\
\text { Ralstonia bacterial wilt of tomato; Ralstonia bacterial wilt of geranium; Brown } \\
\text { rot (potato); southern bacterial wilt (tomato); Moko disease (banana); } \\
\text { Granville wilt (tobacco); Southern Wilt of Geranium }\end{array}$ \\
\hline 1,8 & Rathayibacter toxicus & $\begin{array}{l}\text { Rathayibacter toxicus; Clavibacter toxicus; Rathayibacter poisoning; Annual } \\
\text { ryegrass toxicity; ARGT; Yellow slime disease; Rathay's disease; annual } \\
\text { ryegrass toxicosis; annual ryegrass staggers; parasitized annual ryegrass; } \\
\text { ryegrass toxicity; toxic annual ryegrass; tunicamycin poisoning; wimmera } \\
\text { ryegrass toxicity; Black Springs syndrome; flood plain staggers; blown } \\
\text { grass/beard grass poisoning; corynetoxin poisoning; corynetoxicosis; Stewarts } \\
\text { range syndrome; tunicaminyluracil toxicosis; veldtgrass staggers; bacterial } \\
\text { galls; seed gall nematode }\end{array}$ \\
\hline
\end{tabular}

1 Reconstructed replication competent forms of the 1918 pandemic influenza virus containing any portion of the coding regions of all eight gene segments (Reconstructed1918 Influenza virus)
Reconstructed replication competent forms of the 1918 pandemic influenza virus containing any portion of the coding regions of all eight gene segments (Reconstructed1918 Influenza virus); 1918-like HINI; Spanish Flu; 1918 influenza; reconstructed 1918 influenza virus 


\begin{tabular}{|c|c|c|}
\hline $\begin{array}{l}\text { List(s) } \\
\text { Source }\end{array}$ & Disease or Agent Name & Synonyms, Include Disease/Agent Specified (; separated) \\
\hline 7 & Red sea bream iridoviral disease (RSIVD) & Red sea bream iridoviral disease; RSIVD; Red sea beam iridovirus \\
\hline 9 & Red-Haired Pine Bark Beetle & Red-Haired Pine Bark Beetle; Hylurgus ligniperda Fabricius \\
\hline 1,4 & Ricin & Ricin; Castor bean; Ricinus communis \\
\hline 1,6 & Rickettsiosis, spotted fever & $\begin{array}{l}\text { Rickettsiosis, spotted fever; Rickettsia rickettsii; Rickettsia australis; } \\
\text { Rickettsia ; Rickettsia honei; Rickettsia japonica; Rickettsia felis; Rickettsial } \\
\text { spotted fever; Rocky mountain spotted fever; RMSF; Australian tick typhus; } \\
\text { Tobia fever; Sao Paulo fever; North Asian tick typhus; Flinders Island spotted } \\
\text { fever; Japanese spotted fever }\end{array}$ \\
\hline 1,7 & Rift Valley fever virus & Rift Valley fever virus; Rift Valley fever; RVF \\
\hline 1,7 & Rinderpest virus & Rinderpest virus; Rinderpest; cattle plague; steppe murrain; RPV \\
\hline 6 & Rubella & Rubella; Rubella virus; German measles; congenital rubella syndrome \\
\hline 2 & Salmonella serotype Typhimurium & Salmonella serotype Typhimurium; Salmonella Typhimurium; Salmonellosis \\
\hline 6 & Salmonellosis & Salmonellosis; Salmonella spp; Salmonella enterica \\
\hline 7 & Salmonellosis (Salmonella abortus ovis) & Salmonellosis (Salmonella abortus ovis); Salmonella abortus \\
\hline 1,6 & SARS-associated coronavirus & $\begin{array}{l}\text { SARS-associated coronavirus (SARS-CoV); SARS-associated coronavirus; } \\
\text { SARS virus; SARS-CoV; SARS; Severe Acute Respiratory Syndrome }\end{array}$ \\
\hline 1 & Saxitoxin & $\begin{array}{l}\text { Saxitoxin; saxitoxin; STX; neosaxitoxin; neoSTX; gonyautoxins; GTX; } \\
\text { decarbamoylsaxitoxin; dcSTX; paralytic shellfish poison; PSP }\end{array}$ \\
\hline 1,8 & Sclerophthora rayssiae var zeae & $\begin{array}{l}\text { Sclerophthora rayssiae var zeae; Brown stripe downy mildew; brown stripe } \\
\text { downy mildew of maize; brown stripe downy mildew of corn }\end{array}$ \\
\hline 7 & Scrapie & Scrapie; Scrapie prion \\
\hline 7 & Screw worm, New World & $\begin{array}{l}\text { Screw worm, New World; Cochliomyia hominivorax; New World screw worm } \\
\text { fly; screw worm; myiasis }\end{array}$ \\
\hline 7 & Screw worm, Old world & Screw worm, Old world; Chrysomia bezziana; screw worm; myiasis \\
\hline
\end{tabular}




\begin{tabular}{|c|c|c|}
\hline $\begin{array}{l}\text { List(s) } \\
\text { Source }\end{array}$ & Disease or Agent Name & Synonyms, Include Disease/Agent Specified (; separated) \\
\hline 1,7 & Sheep pox virus & Sheep pox virus; Sheeppox virus; variola ovina; sheeppox; sheep pox \\
\hline 1 & Shigatoxin & $\begin{array}{l}\text { Shigatoxin; Stx; Shiga-like ribosome inactivating proteins; SLT-1; SLT-2; Stx- } \\
\text { 1; Stx-2 }\end{array}$ \\
\hline $1,2,4,6$ & Shigellosis & $\begin{array}{l}\text { Shigellosis; Shigella spp.; Shigella flexneri; Shigella dysenteriae; Shigella } \\
\text { boydii; Shigella sonnei; bacillary dystentery; Marlow syndrome }\end{array}$ \\
\hline 9 & Sirex Woodwasp & Sirex Woodwasp; Sirex noctilio \\
\hline 9 & Soapberry Borer & Soapberry Borer; Agrilus prionurus \\
\hline 7 & Spring viremia of carp & $\begin{array}{l}\text { Spring viremia of carp; spring viremia of carp virus; SVCV; Infectious Dropsy } \\
\text { of Carp; Infectious Ascites; Hydrops; Red Contagious Disease; Rubella; } \\
\text { Hemorrhagic Septicemia }\end{array}$ \\
\hline 9 & Spruce Aphid & Spruce Aphid; Elatobium abietinum \\
\hline 1,4 & Staphylococcal enterotoxins & $\begin{array}{l}\text { Staphylococcal enterotoxins; Staphylococcus aureus enterotoxin; } \\
\text { Staphylococcal enterotoxins; Staphylococcal enterotoxin B; SEB; } \\
\text { Staphylococcal enterotoxins A,B,C,D,E subtypes; staphyloenterotoxicosis; } \\
\text { staphyloenterotoxemia; staphylococcal food poisoning }\end{array}$ \\
\hline 5,6 & Staphylococcus aureus infection & Staphylococcus aureus infection; staph; staph aureus; Staphylococcus aureus \\
\hline 6 & Streptococcal toxic shock syndrome & $\begin{array}{l}\text { Streptococcal toxic shock syndrome (STSS); streptococcal toxic shock } \\
\text { syndrome; STSS; toxic shock-like syndrome; TSLS }\end{array}$ \\
\hline 6 & Streptococcus pneumonia, invasive disease & Streptococcus pneumonia, invasive disease (IPD); Streptococcus pneumonie \\
\hline 9 & Sudden Oak Death Syndrome & Sudden Oak Death Syndrome; Phytophthora ramorum \\
\hline 1,7 & Swine vesicular disease & Swine vesicular disease; Swine vesicular disease virus; SVD \\
\hline 1,8 & Synchytrium endobioticum & Synchytrium endobioticum; Potato wart disease; black scab \\
\hline 6 & Syphilis & Syphilis; Treponema pallidum subspecies pallidum; chancre \\
\hline
\end{tabular}




\begin{tabular}{|c|c|c|}
\hline $\begin{array}{l}\text { List(s) } \\
\text { Source }\end{array}$ & Disease or Agent Name & Synonyms, Include Disease/Agent Specified (; separated) \\
\hline 1 & T-2 toxin & $\begin{array}{l}\text { T-2 toxin; alimentary toxic aleukia; fusariotoxin T2; insariotoxin; mycotoxin } \\
\text { T-2; NSC 138780; T-2 mycotoxin }\end{array}$ \\
\hline 7 & Taura syndrome & Taura syndrome; Taura syndrome virus; TSV \\
\hline 6 & Tetanus & Tetanus; Clostridium tetani; lockjaw \\
\hline 1 & Tetrodotoxin & $\begin{array}{l}\text { Tetrodotoxin; Tetrodotoxin; tetrodox; TTX; anhydrotetrodotoxin; 4- } \\
\text { epitetrodotoxin; tetrodonic acid; pufferfish poisoning }\end{array}$ \\
\hline 7 & Theileriasis (Theileria annulata, T. parva) & Theileriasis; Theileria annulata; Theileria parva; theileriasis; theileria \\
\hline 9 & Thousand Canker Disease & Thousand Canker Disease; Geosmithia morbida \\
\hline 6 & Toxic shock syndrome (non-Strep) & Toxic shock syndrome (non-Strep); toxic shock syndrome; TSS \\
\hline 7 & Transmissible gastroenteritis & $\begin{array}{l}\text { Transmissible gastroenteritis; Transmissible gastroenteritis virus; TGEV; } \\
\text { transmissible gastroenteritis; TGE }\end{array}$ \\
\hline 6,7 & Trichinellosis & Trichinellosis; Trichinela spiralis \\
\hline 7 & Tritrichomonas foetus & Tritrichomonas foetus \\
\hline 7 & Trypanosomiasis & $\begin{array}{l}\text { Trypanosomiasis; Trypanosoma congolense, Trypanosoma vivax; } \\
\text { Trypanosomabrucei brucei; Trypanosoma evansi; Surra }\end{array}$ \\
\hline 5,6 & Tuberculosis & $\begin{array}{l}\text { Tuberculosis; TB; Mycobacterium tuberculosis; Mycobacterium avium; } \\
\text { Mycobacterium bovis; consumption }\end{array}$ \\
\hline 7 & Turkey rhinotracheitis & Turkey rhinotracheitis; avian metapneumovirus; aMPV \\
\hline 6 & Typhoid Fever & $\begin{array}{l}\text { Typhoid Fever; Salmonella typhi; gastric fever; abdominal typhus; infantile } \\
\text { remittant fever; slow fever; nervous fever; pythogenic fever }\end{array}$ \\
\hline 1,4 & Typhus fever (Rickettsia prowazekii) & $\begin{array}{l}\text { Typhus fever; Rickettsia prowazekii; typhus; epidemic typhus; camp fever; jail } \\
\text { fever; hospital fever; ship fever; famine fever; putrid fever; petechial fever; } \\
\text { epidemic louse-borne typhus; louse-borne typhus }\end{array}$ \\
\hline 5 & Vancomycin-intermediate Staphylococcus aureus & $\begin{array}{l}\text { Vancomycin-intermediate Staphylococcus aureus; Staphylococcus aureus; } \\
\text { VISA }\end{array}$ \\
\hline 5 & Vancomycin-resistant Enterococci & Vancomycin-resistant Enterococci; Enterococci spp; VRE \\
\hline
\end{tabular}




\begin{tabular}{|c|c|c|}
\hline $\begin{array}{l}\text { List(s) } \\
\text { Source }\end{array}$ & Disease or Agent Name & Synonyms, Include Disease/Agent Specified (; separated) \\
\hline 5 & Vancomycin-resistant Staphylococcus aureus & Vancomycin-resistant Staphylococcus aureus; Staphylococcus aureus; VRSA \\
\hline 6 & Varicella & $\begin{array}{l}\text { Varicella; Varicella zoster; Chicken pox virus; varicella zoster virus; zoster } \\
\text { virus; human herpes virus type 3; chickenpox }\end{array}$ \\
\hline $1,4,6$ & Variola major virus (Smallpox virus) & $\begin{array}{l}\text { Variola major virus (Smallpox virus); smallpox; Variola major; Variola virus; } \\
\text { VAR; Variola vera }\end{array}$ \\
\hline 1 & Variola minor virus (Alastrim & $\begin{array}{l}\text { Variola minor virus (Alastrim); Variola alastrim; Variola minor; alastrim; } \\
\text { white pox; kaffir pox; Cuban itch; West Indian pox; milk pox; pseudovariola }\end{array}$ \\
\hline 1 & Venezuelan Equine Encephalitis virus & $\begin{array}{l}\text { Venezuelan Equine Encephalitis virus; Venezuelan equine encephalitis; VEE; } \\
\text { Venezuelan equine encephalomyelitis virus }\end{array}$ \\
\hline 1,7 & $\begin{array}{l}\text { Vesicular stomatitis virus (exotic): Indiana subtypes VSV- } \\
\text { IN2, VSV-IN3 }\end{array}$ & $\begin{array}{l}\text { Vesicular stomatitis virus (exotic): Indiana subtypes VSV-IN2, VSV-IN3; } \\
\text { Vesicular stomatitis; Vesicular stomatitis virus; VSV; Indiana subtype VSV- } \\
\text { IN2; Indiana subtype VSV-IN3; vesicular stomatitis Indiana virus; VSIV }\end{array}$ \\
\hline 6 & Vibriosis & Vibriosis; Vibrio vulnificus; Vibrio parahaemolyticus \\
\hline 9 & Viburnum leaf beetle & Viburnum leaf beetle; Pyrrhalta viburni \\
\hline 7 & Viral hemorrhagic septicemia & $\begin{array}{l}\text { Viral hemorrhagic septicemia (VHS); Viral hemorrhagic septicemia virus; } \\
\text { VHSV; Viral hemorrhagic septicemia; VHS }\end{array}$ \\
\hline 9 & Walnut Twig Beetle & Walnut Twig Beetle; Pityophthorus juglandis; Thousand Cankers disease \\
\hline 9 & White Pine Blister Rust & White Pine Blister Rust; Cronartium ribicola \\
\hline 7 & White spot disease & White spot disease; Ichthyophthirius multifiliis; Ich; Ick \\
\hline 7 & White tail disease & $\begin{array}{l}\text { White tail disease; Macrobrachium rosenbergii Nodavirus; MrNV; extra } \\
\text { small virus; XSV }\end{array}$ \\
\hline 1,8 & $\begin{array}{l}\text { Xanthomonas oryzae pv. oryzae and X. oryzae pv. } \\
\text { oryzicola }\end{array}$ & $\begin{array}{l}\text { Xanthomonas oryzae pv. oryzae and X. oryzae pv. Oryzicola; Xanthomonas } \\
\text { oryzae; Rice blight disease; Bacterial leaf blight; BLB; Kresek disease; } \\
\text { Bacterial leaf streak; BLS }\end{array}$ \\
\hline
\end{tabular}


De-duplicated List of Agents, Toxins, and Pathogens of Interest

\begin{tabular}{cll}
\hline $\begin{array}{c}\text { List(s) } \\
\text { Source }\end{array}$ & Disease or Agent Name & Synonyms, Include Disease/Agent Specified (; separated) \\
\hline $\mathbf{1 , 8}$ & Xylella fastidiosa (citrus variegated chlorosis strain) & $\begin{array}{l}\text { Xylella fastidiosa (citrus variegated chlorosis strain); Pierce's disease; } \\
\text { California vine disease; Anaheim disease (grapevine); leaf scorch (almond); } \\
\text { dwarf (lucerne); phony disease (peach); leaf scald (plum); leaf scorch (elm, } \\
\text { oak, plane, mulberry, maple); variegated chlorosis (citrus) }\end{array}$ \\
& & \\
& & Yellow Fever; Yellow fever virus; Yellow Jack; Bronze John \\
$\mathbf{6}$ & Yellow Fever & Yellowhead disease; Yellowhead virus \\
$\mathbf{7}$ & Yellowhead disease & $\begin{array}{l}\text { Yersinia pestis; Plague bacteria; Plague; bubonic plague; pneumonic plague; } \\
\text { Black Death }\end{array}$ \\
\hline $\mathbf{1 , 4 6}$ & Yersinia pestis & \\
\hline
\end{tabular}




\section{Appendix D}

\section{Prioritized List of Agents for BioCat ${ }^{1}$}

The recommendation for a prioritized list of biological agents is shown in the table below. The list is based on the Tier 1 agents and toxins identified from the "HHS and USDA Select Agents and Toxins List." ${ }^{2}$ Tier 1 agents are thought to be at particularly high risk for deliberate misuse. ${ }^{3}$ Five additional agents are also included: pandemic influenza, endosulfan, chlorpyrifos, Ralstonia solanacearum, and citrus greening disease. Influenza is included due to its known potential impacts on human health as well as infrastructure. Endosulfan and chlorpyrifos are highly toxic chemical compounds that have a history of use as pesticides; food and/or water contamination are potential concerns. Two plant diseases were added as well to ensure coverage for this important NBIS domain.

The agents listed below include the human, animal, plant, food, and environment (HAPFE) categories that NBIC is charged with monitoring. Because of significant differences in the means of exposure, the types of models required can vary greatly between agents, and it is acknowledged that there may be gaps in the available model coverage. This list is not meant to be comprehensive but to provide a range of high-priority agents and toxins suitable for analysis using BioCat models.

Table D.1. Prioritized Agents of Interest for BioCat Analysis

\begin{tabular}{|c|c|}
\hline Agent & NBIS Domain Affected \\
\hline Bacillus anthracis & Human, Animal, Environment \\
\hline Botulinum toxin & Food \\
\hline Burkholderia mallei & Human, Animal \\
\hline Burkholderia pseudomallei & Human, Animal \\
\hline Chlorpyrifos (Dursban) & Environment, Food \\
\hline $\begin{array}{l}\text { Citrus Greening, Huanglongbing (HLB) of } \\
\text { citrus, Candidatus Liberibacter americanus }\end{array}$ & Plants \\
\hline Endosulfan & Environment, Food \\
\hline Foot and Mouth Disease (FMD) & Animal \\
\hline Francisella tularensis & Human, Animal \\
\hline Influenza (pandemic) & Human, Animal \\
\hline Ralstonia solanacearum & Plants \\
\hline Rinderpest virus & Animal \\
\hline SARS & Human \\
\hline Variola (major and minor) & Human \\
\hline $\begin{array}{l}\text { Viral hemorrhagic fevers including Ebola and } \\
\text { Marburg }\end{array}$ & Human, Animal \\
\hline Yersinia pestis & Human, Animal \\
\hline
\end{tabular}

\footnotetext{
${ }^{1}$ List received from the client via email on April 10, 2013.

${ }^{2}$ http://www.selectagents.gov/select\%20agents\%20and\%20toxins\%20list.html

${ }^{3}$ http://www.asm.org/index.php/public-policy-2/97-policy/documents/8417-sa-10-9-12
} 



\section{Appendix E}

\section{Disease Forecast and Prediction Model Evaluation Metrics \& Definitions}

\begin{tabular}{|c|c|c|c|c|c|}
\hline Tier (1-3) & Term & Definition & Source & Staffing & Notes \\
\hline 1 & Event-type I & $\begin{array}{l}\text { First-pass identification of the disease, agent and } \\
\text { vector of interest in the article. }\end{array}$ & & \multirow{10}{*}{$\begin{array}{l}\text { Tier } 1 \text { data } \\
\text { collection will be } \\
\text { conducted by a } \\
\text { research associate. }\end{array}$} & \\
\hline 1 & Disease Specific & $\begin{array}{l}\text { The causative agent of the event being modeled } \\
\text { is disease specific. }\end{array}$ & & & \\
\hline 1 & Agent/Pathogen/Toxin/Pest & $\begin{array}{l}\text { The agent(s)/pathogen(s)/toxin(s)/pest(s) of the } \\
\text { event being modeled. }\end{array}$ & Client provided lists & & \\
\hline 1 & Vector & $\begin{array}{l}\text { An invertebrate that transmits a pathogen from } \\
\text { reservoir to host. }\end{array}$ & & & \\
\hline 1 & Operational Aspects I & $\begin{array}{l}\text { First pass to identify characteristics of the model } \\
\text { being evaluated. }\end{array}$ & & & \\
\hline 1 & Event Prediction & $\begin{array}{l}\text { The model predicts an event/outbreak is } \\
\text { expected to occur in the future (left - before an } \\
\text { event). }\end{array}$ & & & \\
\hline 1 & Event Forecast & $\begin{array}{l}\text { The model makes estimations about an } \\
\text { event/outbreak occurring at some specified } \\
\text { future date (the index case exists, what is the } \\
\text { projected - estimated } \\
\text { spread/trajectory/R0/infectivity/transmissibility). }\end{array}$ & & & \\
\hline 1 & Technological Maturity & $\begin{array}{l}\text { The level of maturity of a particular model in } \\
\text { comparison to others. }\end{array}$ & & & \\
\hline 1 & Verified or Validated & $\begin{array}{l}\text { First-pass identification of whether or not the } \\
\text { model has been verified and/or validated (Does } \\
\text { the article mention any type of validation or } \\
\text { verification?). }\end{array}$ & & & \\
\hline 1 & Model Identification I & $\begin{array}{l}\text { First-pass identification of the Model discussed } \\
\text { in the article. }\end{array}$ & & & \\
\hline
\end{tabular}


Disease Forecast and Prediction Model Evaluation Metrics \& Definitions

\begin{tabular}{|c|c|c|c|c|c|}
\hline Tier (1-3) & Term & Definition & Source & Staffing & Notes \\
\hline 1 & Model Name & $\begin{array}{l}\text { The name of the model (e.g., EpiCast, FLuTe, } \\
\text { IT-CI, ...). }\end{array}$ & & & \\
\hline 2 & Model Identification II & $\begin{array}{l}\text { Second pass and more detailed information } \\
\text { extraction of the Model discussed in the article. }\end{array}$ & & \multirow{13}{*}{$\begin{array}{l}\text { Tier } 2 \text { data } \\
\text { collection will be } \\
\text { conducted by a } \\
\text { post-doc, } \\
\text { advanced } \\
\text { undergrad/Master's } \\
\text { level intern or } \\
\text { S\&E II/III. }\end{array}$} & \\
\hline 2 & Owner & $\begin{array}{l}\text { The "owner" of the model used in the article. } \\
\text { This can be a person, university, corporation or } \\
\text { organization. }\end{array}$ & & & \\
\hline 2 & Website & $\begin{array}{l}\text { The website where additional information about } \\
\text { the model can be found. }\end{array}$ & & & \\
\hline 2 & Corresponding Author & $\begin{array}{l}\text { The article's corresponding author as identified } \\
\text { in the full-text document. }\end{array}$ & & & \\
\hline 2 & $\begin{array}{l}\text { Corresponding Author } \\
\text { Phone Number }\end{array}$ & $\begin{array}{l}\text { The corresponding author's phone number as } \\
\text { identified in the full-text document. }\end{array}$ & & & \\
\hline 2 & $\begin{array}{l}\text { Corresponding Author } \\
\text { Email Address }\end{array}$ & $\begin{array}{l}\text { The corresponding author's email address as } \\
\text { identified in the full-text document. }\end{array}$ & & & \\
\hline 2 & Model Creation Year & The year the model was created. & & & \\
\hline 2 & Revision & $\begin{array}{l}\text { Is this a modification of the original model } \\
\text { (same owner or different). }\end{array}$ & & & \\
\hline 2 & Revision Date & The date the model was revised/modified. & & & \\
\hline 2 & This Model Rocks & $\begin{array}{l}\text { This is a subjective opinion of the PNNL SME } \\
\text { on whether this model is "cream of the crop" or } \\
\text { "pit of the pot." }\end{array}$ & & & \\
\hline 2 & Event-type II & $\begin{array}{l}\text { Second-pass identification of the affected } \\
\text { population detailed in the article. }\end{array}$ & & & \\
\hline 2 & $\begin{array}{l}\text { Population (Species) } \\
\text { Affected Identified }\end{array}$ & $\begin{array}{l}\text { The specific affected population/species } \\
\text { identified and modeled in the article. }\end{array}$ & & & \\
\hline 2 & Technological Maturity & $\begin{array}{l}\text { The level of maturity of a particular model in } \\
\text { comparison to others. }\end{array}$ & $\begin{array}{l}\text { Metrics for Evaluation } \\
\text { draft report (2010) }\end{array}$ & & \\
\hline
\end{tabular}


Disease Forecast and Prediction Model Evaluation Metrics \& Definitions

\begin{tabular}{|c|c|c|c|c|c|}
\hline Tier (1-3) & Term & Definition & Source & Staffing & Notes \\
\hline 2 & $\begin{array}{l}\text { Type of Validation and } \\
\text { Verification }\end{array}$ & $\begin{array}{l}\text { The method used to verify and/or validate the } \\
\text { model's maturity. }\end{array}$ & & & \\
\hline 2 & $\begin{array}{l}\text { In Use in an Operational } \\
\text { Environment }\end{array}$ & $\begin{array}{l}\text { The model is or is not in use in an operational } \\
\text { environment. }\end{array}$ & & & \\
\hline 3 & Operational Aspects III & $\begin{array}{l}\text { Third pass to identify characteristics of the } \\
\text { model being evaluated. }\end{array}$ & & \multirow{6}{*}{$\begin{array}{l}\text { Tier } 3 \text { data } \\
\text { collection will be } \\
\text { conducted by an } \\
\text { advanced post- } \\
\text { doc/S\&E III/IV }\end{array}$} & \\
\hline 3 & Spatial & $\begin{array}{l}\text { Models which forecast the geographic spread of } \\
\text { a disease after it occurs based on the relationship } \\
\text { between the outbreak and primary geospatial } \\
\text { factors. }\end{array}$ & $\begin{array}{l}\text { PLoS ONE } \\
\text { Manuscript }\end{array}$ & & \\
\hline 3 & Ecological Niche* & $\begin{array}{l}\text { Computational models/algorithms to predict the } \\
\text { distribution of species in geographic space on } \\
\text { the basis of a mathematical representation of } \\
\text { their known distribution in environmental space. }\end{array}$ & Wikipedia & & $\begin{array}{l}\text { * Also called } \\
\text { environmental } \\
\text { niche modeling, } \\
\text { species distribution } \\
\text { modeling, } \\
\text { predictive habitat } \\
\text { distribution } \\
\text { modeling, and } \\
\text { climate envelope } \\
\text { modeling. }\end{array}$ \\
\hline 3 & Event-Based & $\begin{array}{l}\text { Models which attempt to identify outbreaks } \\
\text { either through sentinel groups or through the } \\
\text { collection of real-time diagnostic, clinical, or } \\
\text { syndromic data. }\end{array}$ & $\begin{array}{l}\text { PLoS ONE } \\
\text { Manuscript }\end{array}$ & & \\
\hline 3 & Dynamical & $\begin{array}{l}\text { Models which examine how a specific disease } \\
\text { moves through a population. }\end{array}$ & $\begin{array}{l}\text { PLoS ONE } \\
\text { Manuscript }\end{array}$ & & \\
\hline 3 & Statistical Models & $\begin{array}{l}\text { Models which are a formalization of } \\
\text { relationships between variables in the form of } \\
\text { mathematical equations. }\end{array}$ & Wikipedia & & \\
\hline
\end{tabular}


Disease Forecast and Prediction Model Evaluation Metrics \& Definitions

\begin{tabular}{|c|c|c|c|c|c|}
\hline Tier (1-3) & Term & Definition & Source & Staffing & Notes \\
\hline 3 & Agent Based Model & $\begin{array}{l}\text { Computational models for simulating the actions } \\
\text { and interactions of autonomous agents (both } \\
\text { individual or collective entities such as } \\
\text { organizations or groups) with a view to } \\
\text { assessing their effects on the system as a whole. }\end{array}$ & Wikipedia & & \\
\hline 3 & Accessibility & $\begin{array}{l}\text { The degree to which and mechanism by which } \\
\text { the model is made available, e.g., plug-and-play, } \\
\text { downloadable, etc. }\end{array}$ & $\begin{array}{l}\text { Corley et al. }(2012)^{1} \\
\text { and modified as } \\
\text { needed }\end{array}$ & & \\
\hline 3 & $\begin{array}{l}\text { Run Time, Complexity, } \\
\text { Capabilities Required }\end{array}$ & $\begin{array}{l}\text { Characteristics required for executing the model } \\
\text { effectively. }\end{array}$ & & & \\
\hline 3 & $\begin{array}{c}\text { Geographic and } \\
\text { Population Coverage }\end{array}$ & $\begin{array}{l}\text { Geographic area and population size of the } \\
\text { organism(s) being modeled. }\end{array}$ & & & \\
\hline 3 & Input Geography & Geographic area attributes used as model input. & & & \\
\hline 3 & Output Geography & $\begin{array}{l}\text { Geographic area attributes generated as model } \\
\text { output. }\end{array}$ & & & \\
\hline 3 & Local & $\begin{array}{l}\text { A geographic area bounded by city or county } \\
\text { limits. }\end{array}$ & $\begin{array}{l}\text { Based on LANL's } \\
\text { work and modified as } \\
\text { needed }\end{array}$ & & \\
\hline 3 & Provincial/State & $\begin{array}{l}\text { A geographic area within the political } \\
\text { boundaries of one government, such as a } \\
\text { province or state. }\end{array}$ & $\begin{array}{l}\text { Based on LANL's } \\
\text { work and modified as } \\
\text { needed }\end{array}$ & & \\
\hline 3 & Regional & $\begin{array}{l}\text { A geographic area defined by similar features } \\
\text { and location, such as the Columbia Basin or } \\
\text { Latin America. }\end{array}$ & $\begin{array}{l}\text { Based on LANL's } \\
\text { work and modified as } \\
\text { needed }\end{array}$ & & \\
\hline 3 & National & A geographic area composed of a country. & $\begin{array}{l}\text { Based on LANL's } \\
\text { work and modified as } \\
\text { needed }\end{array}$ & & \\
\hline
\end{tabular}

\footnotetext{
${ }^{1}$ Courtney D. Corley, Mary J. Lancaster, et al. Assessing the Continuum of Event-Based Biosurveillance Through an Operational Lens. Biosecurity and
} Bioterrorism: Biodefense Strategy, Practice, and Science. March 2012. doi:10.1089/bsp.2011.0096. PNNL-SA-77400 
Disease Forecast and Prediction Model Evaluation Metrics \& Definitions

\begin{tabular}{|c|c|c|c|c|c|}
\hline Tier (1-3) & Term & Definition & Source & Staffing & Notes \\
\hline 3 & Global & $\begin{array}{l}\text { A geographic area defined as the entire } \\
\text { world/international in scope. }\end{array}$ & $\begin{array}{l}\text { Based on LANL's } \\
\text { work and modified as } \\
\text { needed }\end{array}$ & & \\
\hline 3 & Vector Population Size & The size of the vector population. & & & \\
\hline 3 & $\begin{array}{l}\text { Modeled Species } \\
\text { Population Size }\end{array}$ & The population size of the species impacted. & & & \\
\hline 3 & Data Input & $\begin{array}{l}\text { Data input is a general characterization of the } \\
\text { type of model used to produce results. }\end{array}$ & $\begin{array}{l}\text { PLoS ONE and Corley } \\
\text { et al. (2012) }\end{array}$ & & \\
\hline 3 & $\begin{array}{l}\text { Epidemiological Data from } \\
\text { the Same Location }\end{array}$ & $\begin{array}{l}\text { Models which take into account epidemiological } \\
\text { characteristics of the disease from the same } \\
\text { location. }\end{array}$ & PLoS ONE manuscript & & \\
\hline 3 & $\begin{array}{l}\text { Epidemiological Data from } \\
\text { Difference Location }\end{array}$ & $\begin{array}{l}\text { Models which take into account epidemiological } \\
\text { characteristics of the disease from different } \\
\text { same locations. }\end{array}$ & PLoS ONE manuscript & & \\
\hline 3 & $\begin{array}{l}\text { Governmental and Non- } \\
\text { Governmental } \\
\text { Organizations }\end{array}$ & $\begin{array}{l}\text { Models which use data acquired from } \\
\text { governmental or non-governmental } \\
\text { organizations. }\end{array}$ & PLoS ONE manuscript & & \\
\hline 3 & Literature & $\begin{array}{l}\text { Models which use any form data excluding } \\
\text { epidemiological, weather, or population data. }\end{array}$ & $\begin{array}{l}\text { PLoS ONE manuscript } \\
\text { and modified as } \\
\text { needed }\end{array}$ & & \\
\hline 3 & Satellite/Remote Sensing & $\begin{array}{l}\text { Models which use data acquired via satellite or } \\
\text { remote sensing technologies. }\end{array}$ & PLoS ONE manuscript & & \\
\hline 3 & Simulated & $\begin{array}{l}\text { Models which are simulated using software or } \\
\text { statistical techniques. }\end{array}$ & $\begin{array}{l}\text { PLoS ONE manuscript } \\
\text { and modified as } \\
\text { needed }\end{array}$ & & \\
\hline 3 & Laboratory Diagnostic & $\begin{array}{l}\text { Models developed using laboratory diagnostic } \\
\text { data. }\end{array}$ & PLoS ONE manuscript & & \\
\hline 3 & Expert Opinion & $\begin{array}{l}\text { Models based on expert opinion - does not } \\
\text { specify from whom or what type of data was } \\
\text { used in the modeling. }\end{array}$ & PLoS ONE manuscript & & \\
\hline 3 & Output & $\begin{array}{l}\text { Output is the information/data/analysis produced } \\
\text { after running a model. }\end{array}$ & $\begin{array}{l}\text { Corley et al. (2012) } \\
\text { and modified as } \\
\text { needed }\end{array}$ & & \\
\hline
\end{tabular}


Disease Forecast and Prediction Model Evaluation Metrics \& Definitions

\begin{tabular}{|c|c|c|c|c|c|}
\hline Tier (1-3) & Term & Definition & Source & Staffing & Notes \\
\hline 3 & Output Content & $\begin{array}{l}\text { Model output may be quantitative or qualitative } \\
\text { and may include probabilities, forecasts, digests, } \\
\text { counts, warnings, or lists of outlying } \\
\text { observations. }\end{array}$ & $\begin{array}{l}\text { Corley et al. (2012) } \\
\text { and modified as } \\
\text { needed }\end{array}$ & & \\
\hline 3 & Sustainability & $\begin{array}{l}\text { A measure of how long model output may be } \\
\text { considered valid and confident. }\end{array}$ & $\begin{array}{l}\text { Corley et al. (2012) } \\
\text { and modified as } \\
\text { needed }\end{array}$ & & \\
\hline 3 & Cost & $\begin{array}{l}\text { Cost represents the overarching financial } \\
\text { investment (in USD) of purchasing the model, } \\
\text { purchasing equipment to run the model, staffing } \\
\text { expertise, and any other expense required to } \\
\text { develop or sustain the model. }\end{array}$ & $\begin{array}{l}\text { Corley et al. (2012) } \\
\text { and modified as } \\
\text { needed }\end{array}$ & & \\
\hline 3 & $\begin{array}{l}\text { Research, development, } \\
\text { testing, and evaluation }\end{array}$ & $\begin{array}{l}\text { The cost (in USD) to perform research, and to } \\
\text { construct, prepare, develop, test, and evaluate } \\
\text { the model. }\end{array}$ & $\begin{array}{l}\text { Corley et al. (2012) } \\
\text { and modified as } \\
\text { needed }\end{array}$ & & \\
\hline 3 & Operations & $\begin{array}{l}\text { The cost to maintain and operate the model. This } \\
\text { includes any projected storage, data acquisition, } \\
\text { or staffing expense to maintain model } \\
\text { performance. }\end{array}$ & $\begin{array}{l}\text { Corley et al. (2012) } \\
\text { and modified as } \\
\text { needed }\end{array}$ & & \\
\hline 3 & Government funded & $\begin{array}{l}\text { A tribal, local, regional, national, or } \\
\text { international governmental agency funded the } \\
\text { development and/or operations of the model. }\end{array}$ & $\begin{array}{l}\text { Corley et al. (2012) } \\
\text { and modified as } \\
\text { needed }\end{array}$ & & \\
\hline
\end{tabular}




\section{Appendix F}

\section{BioCat Evaluation \& Workflow Data Fields}

\begin{tabular}{|c|c|c|c|c|c|c|}
\hline $\begin{array}{l}\text { Triage } \\
\text { Level }\end{array}$ & Metric & Submetric & $\begin{array}{l}\text { Requir } \\
\text { ed }\end{array}$ & $\begin{array}{l}\text { Type } \\
\text { of } \\
\text { Field }\end{array}$ & $\begin{array}{l}\text { Allowed } \\
\text { Value }\end{array}$ & Notes \\
\hline \multirow{8}{*}{1} & \multirow{3}{*}{ Event-type (I) } & Disease Specific & $\mathrm{Y}$ & $\begin{array}{l}\text { Yes or } \\
\text { No } \\
\text { (Radio } \\
\text { / Drop } \\
\text { Down) }\end{array}$ & & \\
\hline & & $\begin{array}{c}\text { Agent/Pathogen/Toxi } \\
\text { n/Pest }\end{array}$ & $\mathrm{N}$ & $\begin{array}{l}\text { Check } \\
\text { Boxes }\end{array}$ & & $\begin{array}{l}\text { If Disease } \\
\text { Specific is Y, } \\
\text { then pop-up } \\
\text { Agent selection }\end{array}$ \\
\hline & & Vector & $\mathrm{N}$ & $\begin{array}{l}\text { String } \\
\text { Field } \\
\text { (Manua } \\
\text { 1) ';' } \\
\text { separat } \\
\text { ed }\end{array}$ & & \\
\hline & \multirow{3}{*}{$\begin{array}{l}\text { Operational Aspect } \\
\text { (I) }\end{array}$} & Event Prediction & $\mathrm{Y}$ & $\begin{array}{l}\text { Yes or } \\
\text { No } \\
\text { (Radio } \\
\text { / Drop } \\
\text { Down) } \\
\end{array}$ & & \\
\hline & & Event Forecast & $\mathrm{Y}$ & $\begin{array}{l}\text { Yes or } \\
\text { No } \\
\text { (Radio } \\
\text { / Drop } \\
\text { Down) }\end{array}$ & & \\
\hline & & Verified or Validated & $\mathrm{Y}$ & $\begin{array}{l}\text { Yes or } \\
\text { No } \\
\text { (Radio } \\
\text { / Drop } \\
\text { Down) }\end{array}$ & & \\
\hline & $\begin{array}{l}\text { Technological } \\
\text { Maturity (I) }\end{array}$ & Model Name & $\mathrm{N}$ & $\begin{array}{l}\text { String } \\
\text { Field } \\
\text { (Manua } \\
\text { 1) } \\
\end{array}$ & & \\
\hline & $\begin{array}{c}\text { Model } \\
\text { Identification (I) }\end{array}$ & $\begin{array}{l}\text { Second Look } \\
\text { Required }\end{array}$ & $\mathrm{N}$ & $\begin{array}{l}\text { Yes or } \\
\text { No } \\
\text { (Radio } \\
\text { / Drop } \\
\text { Down) }\end{array}$ & & $\begin{array}{l}\text { If Y, trigger } \\
\text { workflow AND } \\
\text { hide this field } \\
\text { from public/user } \\
\text { view. }\end{array}$ \\
\hline 2 & $\begin{array}{c}\text { Model } \\
\text { Identification (II) }\end{array}$ & Owner & $\mathrm{N}$ & $\begin{array}{l}\text { String } \\
\text { Field } \\
\text { (Manua } \\
\text { 1) } \\
\end{array}$ & & $\begin{array}{l}\text { Firstname } \\
\text { Lastname }\end{array}$ \\
\hline
\end{tabular}


Disease Forecast and Prediction Model Evaluation Metrics \& Definitions

\begin{tabular}{|c|c|c|c|c|c|c|}
\hline $\begin{array}{l}\text { Triage } \\
\text { Level }\end{array}$ & Metric & Submetric & $\begin{array}{l}\text { Requir } \\
\text { ed }\end{array}$ & $\begin{array}{l}\text { Type } \\
\text { of } \\
\text { Field }\end{array}$ & $\begin{array}{l}\text { Allowed } \\
\text { Value }\end{array}$ & Notes \\
\hline & & Website & $\mathrm{N}$ & $\begin{array}{l}\text { String } \\
\text { Field } \\
\text { (Manua } \\
\text { 1) }\end{array}$ & & \\
\hline & & Corresponding Author & Y & $\begin{array}{l}\text { String } \\
\text { Field } \\
\text { (Manua } \\
\text { 1) } \\
\end{array}$ & & \\
\hline & & $\begin{array}{l}\text { Corresponding Author } \\
\text { Phone Number }\end{array}$ & $\mathrm{N}$ & $\begin{array}{l}\text { Phone } \\
\text { Numbe } \\
r\end{array}$ & & $\begin{array}{l}\text { Phone number } \\
\text { with area code - } \\
\text { US or } \\
\text { international }\end{array}$ \\
\hline & & $\begin{array}{l}\text { Corresponding Author } \\
\text { Email Address }\end{array}$ & $\mathrm{N}$ & $\begin{array}{l}\text { Email } \\
\text { Addres } \\
\mathrm{s}\end{array}$ & & $\begin{array}{l}\text { Valid email } \\
\text { address }\end{array}$ \\
\hline & & Model Creation Year & $\mathrm{N}$ & Date & & $\begin{array}{l}\text { Only Year is } \\
\text { Required }\end{array}$ \\
\hline & & Revision & $\mathrm{N}$ & $\begin{array}{l}\text { Yes or } \\
\text { No } \\
\text { (Radio } \\
\text { / Drop } \\
\text { Down) } \\
\end{array}$ & & \\
\hline & & Revision Date & $\mathrm{N}$ & Date & & $\begin{array}{l}\text { Only Year is } \\
\text { Required }\end{array}$ \\
\hline & & This Model Rocks & $\mathrm{N}$ & $\begin{array}{l}\text { Yes or } \\
\text { No } \\
\text { (Radio } \\
\text { / Drop } \\
\text { Down) }\end{array}$ & & $\begin{array}{l}\text { Hide this field } \\
\text { from public/user } \\
\text { view. }\end{array}$ \\
\hline & \multirow{2}{*}{ Event-type (II) } & $\begin{array}{l}\text { Population (Species) } \\
\text { Affected Identified }\end{array}$ & $\mathrm{Y}$ & $\begin{array}{l}\text { Yes or } \\
\text { No } \\
\text { (Radio } \\
\text { / Drop } \\
\text { Down) }\end{array}$ & & $\begin{array}{l}\text { If Population Y, } \\
\text { prompt to fill in } \\
\text { text box for } \\
\text { Population } \\
\text { Affected (see } \\
\text { row below). }\end{array}$ \\
\hline & & $\begin{array}{c}\text { Population (Species) } \\
\text { Affected }\end{array}$ & $\mathrm{N}$ & $\begin{array}{l}\text { String } \\
\text { Field } \\
\text { (Manua } \\
\text { l) ';' } \\
\text { separat } \\
\text { ed } \\
\end{array}$ & & $\begin{array}{l}\text { If Population Y } \\
\text { (above), prompt } \\
\text { to fill in text box } \\
\text { for names(s) of } \\
\text { Population } \\
\text { Affected. }\end{array}$ \\
\hline & \multirow{3}{*}{$\begin{array}{l}\text { Technological } \\
\text { Maturity (II) }\end{array}$} & \multirow{3}{*}{$\begin{array}{l}\text { Type of Validation } \\
\text { and Verification }\end{array}$} & \multirow{3}{*}{$\mathrm{N}$} & \multirow{3}{*}{$\begin{array}{l}\text { Drop } \\
\text { Down }\end{array}$} & $\begin{array}{l}\text { Statistical } \\
\text { Verification }\end{array}$ & $\begin{array}{l}\text { Need to be able } \\
\text { to choose more } \\
\text { than one. }\end{array}$ \\
\hline & & & & & $\begin{array}{l}\text { Sensitivity } \\
\text { Analysis } \\
\text { (verification) }\end{array}$ & \\
\hline & & & & & $\begin{array}{l}\text { Specificity } \\
\text { and } \\
\text { Sensitivity } \\
\text { (verification) }\end{array}$ & \\
\hline
\end{tabular}


Disease Forecast and Prediction Model Evaluation Metrics \& Definitions

\begin{tabular}{|c|c|c|c|c|c|c|}
\hline $\begin{array}{l}\text { Triage } \\
\text { Level }\end{array}$ & Metric & Submetric & $\begin{array}{l}\text { Requir } \\
\text { ed }\end{array}$ & $\begin{array}{l}\text { Type } \\
\text { of } \\
\text { Field }\end{array}$ & $\begin{array}{l}\text { Allowed } \\
\text { Value }\end{array}$ & Notes \\
\hline & & & & & $\begin{array}{l}\text { Verification } \\
\text { using } \\
\text { Training } \\
\text { Data }\end{array}$ & \\
\hline & & & & & $\begin{array}{l}\text { Validation } \\
\text { using } \\
\text { Temporally } \\
\text { Independent } \\
\text { Data }\end{array}$ & \\
\hline & & & & & $\begin{array}{l}\text { Validation } \\
\text { using } \\
\text { Spatially and } \\
\text { Temporally } \\
\text { Independent } \\
\text { Data } \\
\end{array}$ & \\
\hline & & & & & $\begin{array}{l}\text { Second Look } \\
\text { Required }\end{array}$ & $\begin{array}{l}\text { Trigger } \\
\text { workflow AND } \\
\text { hide this field } \\
\text { from public/user } \\
\text { view. }\end{array}$ \\
\hline & & $\begin{array}{l}\text { In Use in an } \\
\text { Operational } \\
\text { Environment }\end{array}$ & $\mathrm{N}$ & $\begin{array}{l}\text { Yes or } \\
\text { No } \\
\text { (Radio } \\
\text { / Drop } \\
\text { Down) }\end{array}$ & & \\
\hline \multirow{8}{*}{3} & \multirow{8}{*}{$\begin{array}{l}\text { Operational aspects } \\
\text { (III) }\end{array}$} & \multirow{7}{*}{ Type of Model } & \multirow{7}{*}{$\mathrm{Y}$} & \multirow{7}{*}{$\begin{array}{l}\text { Check } \\
\text { Boxes }\end{array}$} & Spatial & $\begin{array}{l}\text { Not mutually } \\
\text { exclusive. Need } \\
\text { to be able to } \\
\text { choose more } \\
\text { than one. }\end{array}$ \\
\hline & & & & & $\begin{array}{l}\text { Ecological } \\
\text { Niche }\end{array}$ & \\
\hline & & & & & Event-Based & \\
\hline & & & & & Dynamical & \\
\hline & & & & & $\begin{array}{l}\text { Statistical } \\
\text { Models }\end{array}$ & \\
\hline & & & & & $\begin{array}{l}\text { Agent Based } \\
\text { Model }\end{array}$ & \\
\hline & & & & & Other & $\begin{array}{l}\text { If selected, } \\
\text { provide string } \\
\text { field (required). }\end{array}$ \\
\hline & & SME Needed (Y/N) & $\mathrm{N}$ & $\begin{array}{l}\text { Yes or } \\
\text { No } \\
\text { (Radio } \\
\text { / Drop } \\
\text { Down) }\end{array}$ & & \\
\hline
\end{tabular}


Disease Forecast and Prediction Model Evaluation Metrics \& Definitions

\begin{tabular}{|c|c|c|c|c|c|c|}
\hline $\begin{array}{l}\text { Triage } \\
\text { Level }\end{array}$ & Metric & Submetric & $\begin{array}{l}\text { Requir } \\
\text { ed }\end{array}$ & $\begin{array}{l}\text { Type } \\
\text { of } \\
\text { Field }\end{array}$ & $\begin{array}{l}\text { Allowed } \\
\text { Value }\end{array}$ & Notes \\
\hline & & Accessibility & $\mathrm{N}$ & $\begin{array}{l}\text { String } \\
\text { Field }\end{array}$ & & $\begin{array}{l}\text { Pop-up } \\
\text { suggestion: } \\
\text { (plug-and-play, } \\
\text { downloadable, } \\
\text { etc.) }\end{array}$ \\
\hline & & $\begin{array}{c}\text { Run Time, } \\
\text { Complexity, } \\
\text { Capabilities Required }\end{array}$ & $\mathrm{N}$ & $\begin{array}{l}\text { String } \\
\text { Field }\end{array}$ & & \\
\hline & \multirow{12}{*}{$\begin{array}{c}\text { Geographic and } \\
\text { Population } \\
\text { Coverage }\end{array}$} & \multirow{5}{*}{ Input Geography } & \multirow{5}{*}{$\mathrm{N}$} & \multirow{5}{*}{$\begin{array}{l}\text { Drop } \\
\text { Down }\end{array}$} & Local & $\begin{array}{l}\text { Need to be able } \\
\text { to choose more } \\
\text { than one. }\end{array}$ \\
\hline & & & & & $\begin{array}{l}\text { Provincial/St } \\
\text { ate }\end{array}$ & \\
\hline & & & & & Regional & \\
\hline & & & & & National & \\
\hline & & & & & Global & \\
\hline & & \multirow{5}{*}{ Output Geography } & \multirow{5}{*}{$\mathrm{N}$} & \multirow{5}{*}{$\begin{array}{l}\text { Drop } \\
\text { Down }\end{array}$} & Local & $\begin{array}{l}\text { Need to be able } \\
\text { to choose more } \\
\text { than one. }\end{array}$ \\
\hline & & & & & $\begin{array}{l}\text { Provincial/St } \\
\text { ate }\end{array}$ & \\
\hline & & & & & Regional & \\
\hline & & & & & National & \\
\hline & & & & & Global & \\
\hline & & $\begin{array}{l}\text { Vector Population } \\
\text { Size }\end{array}$ & $\mathrm{N}$ & $\begin{array}{l}\text { Drop } \\
\text { Down }\end{array}$ & $\begin{array}{l}10 \mathrm{~s} ; 100 \mathrm{~s} ; \\
1000 \mathrm{~s} ; \\
10,000 \mathrm{~s} ; \\
100,000 \mathrm{~s} \\
1,000,000 \mathrm{~s} \\
\end{array}$ & \\
\hline & & $\begin{array}{l}\text { Modeled Species } \\
\text { Population Size }\end{array}$ & $\mathrm{N}$ & $\begin{array}{l}\text { Drop } \\
\text { Down }\end{array}$ & $\begin{array}{l}10 \mathrm{~s} ; 100 \mathrm{~s} \\
1000 \mathrm{~s} ; \\
10,000 \mathrm{~s} ; \\
100,000 \mathrm{~s}, \\
1,000,000 \mathrm{~s}\end{array}$ & \\
\hline & \multirow{2}{*}{ Data Input (III) } & \multirow{2}{*}{ Input Content } & \multirow{2}{*}{$\mathrm{Y}$} & \multirow{2}{*}{$\begin{array}{l}\text { Check } \\
\text { Boxes }\end{array}$} & $\begin{array}{l}\text { Epidemiologi } \\
\text { cal Data } \\
\text { from the } \\
\text { Same } \\
\text { Location }\end{array}$ & \\
\hline & & & & & $\begin{array}{l}\text { Epidemiologi } \\
\text { cal Data } \\
\text { from } \\
\text { Difference } \\
\text { Location }\end{array}$ & \\
\hline
\end{tabular}


Disease Forecast and Prediction Model Evaluation Metrics \& Definitions

\begin{tabular}{|c|c|c|c|c|c|c|}
\hline $\begin{array}{l}\text { Triage } \\
\text { Level }\end{array}$ & Metric & Submetric & $\begin{array}{l}\text { Requir } \\
\text { ed }\end{array}$ & $\begin{array}{l}\text { Type } \\
\text { of } \\
\text { Field }\end{array}$ & $\begin{array}{l}\text { Allowed } \\
\text { Value }\end{array}$ & Notes \\
\hline & & & & & $\begin{array}{l}\text { Governmenta } \\
1 \text { and Non- } \\
\text { Governmenta } \\
1 \\
\text { Organization } \\
\mathrm{s} \\
\end{array}$ & \\
\hline & & & & & Literature & \\
\hline & & & & & $\begin{array}{l}\text { Satellite/Rem } \\
\text { ote Sensing }\end{array}$ & \\
\hline & & & & & Simulated & \\
\hline & & & & & $\begin{array}{l}\text { Laboratory } \\
\text { Diagnostic }\end{array}$ & \\
\hline & & & & & $\begin{array}{l}\text { Expert } \\
\text { Opinion }\end{array}$ & \\
\hline & \multirow{2}{*}{ Output (III) } & Output Content & $\mathrm{Y}$ & $\begin{array}{l}\text { String } \\
\text { Field } \\
\text { (Manua } \\
\text { 1) ';' } \\
\text { separat } \\
\text { ed }\end{array}$ & & $\begin{array}{l}\text { Pop-up } \\
\text { suggestion: } \\
\text { (e.g., structured } \\
\text { warning output, } \\
\text { probabilities, } \\
\text { etc.) }\end{array}$ \\
\hline & & Sustainability & $\mathrm{N}$ & $\begin{array}{l}\text { String } \\
\text { Field } \\
\text { (Manua } \\
\text { 1) ';' } \\
\text { separat } \\
\text { ed }\end{array}$ & & $\begin{array}{l}\text { Pop-up example: } \\
\text { For how long } \\
\text { are the } \\
\text { forecasts/predict } \\
\text { ions confident? }\end{array}$ \\
\hline & \multirow{3}{*}{ Cost (III) } & $\begin{array}{c}\text { Research, } \\
\text { development, testing, } \\
\text { and evaluation }\end{array}$ & $\mathrm{N}$ & $\begin{array}{l}\text { Drop } \\
\text { Down }\end{array}$ & $\begin{array}{l}\$ 10 \mathrm{~s} ; \$ 100 \mathrm{~s} ; \\
\$ 1000 \mathrm{~s} \\
\$ 10,000 \mathrm{~s} \\
\$ 100,000 \mathrm{~s} \\
\$ 1,000,000 \mathrm{~s}\end{array}$ & \\
\hline & & Operations & $\mathrm{N}$ & $\begin{array}{l}\text { Drop } \\
\text { Down }\end{array}$ & $\begin{array}{l}\$ 10 \mathrm{~s} ; \$ 100 \mathrm{~s} ; \\
\$ 1000 \mathrm{~s} ; \\
\$ 10,000 \mathrm{~s} ; \\
\$ 100,000 \mathrm{~s} \\
\$ 1,000,000 \mathrm{~s}\end{array}$ & \\
\hline & & Government funded & $\mathrm{Y}$ & $\begin{array}{l}\text { Drop } \\
\text { Down } \\
\text { or } \\
\text { Check } \\
\text { boxes } \\
\end{array}$ & $\begin{array}{l}\text { Y, N, Not } \\
\text { Indicated }\end{array}$ & \\
\hline
\end{tabular}






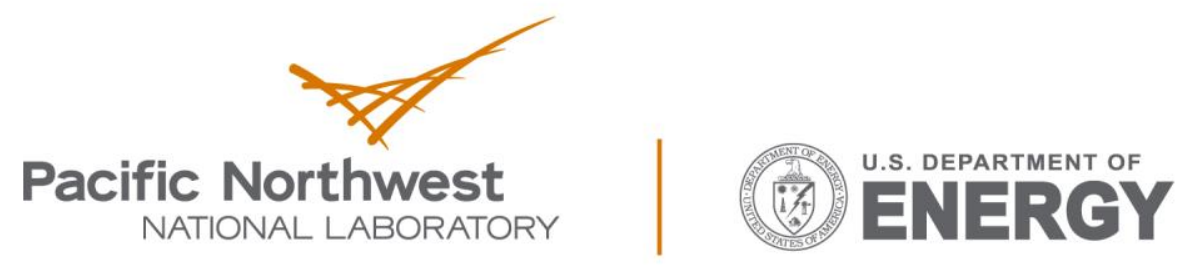

Proudly Operated by Battelle Since 1965

902 Battelle Boulevard

P.O. Box 999

Richland, WA 99352

1-888-375-PNNL (7665)

www.pnnl.gov 